\title{
The Jordan Valley
}

\subsection{Introduction}

In March 2014, a Baseline Report was prepared and published by EcoPeace Middle East on its website which the current situation in the Jordan Valley, including physical and environmental characteristics of the valley, governance structures in the valley, and the population living in the valley and its socioeconomic status. This report concluded with the major challenges that the valley faces, both from national perspectives and in terms of trans-boundary challenges. This section here provides a summary of this baseline report.

\subsection{The Jordan Valley}

\subsubsection{Land Use}

The Jordan Valley (Arabic: الغور, Al-Ghor; Hebrew: עמק הירדן, Hayarden Emek) forms part of the larger Jordan Rift Valley. The internationally recognized World Heritage values of the Jordan Valley are strongly related to its unique historic, religious, cultural, economic, and environmental values, due to its typical rift valley topography. The lower part of the Jordan River (LJR) originates at the Sea of Galilee and meanders along $200 \mathrm{~km}$ down to the Dead Sea through the Jordan Valley. About 600,000 people living in the study area on both sides of the lower part of the Jordan River, including about 55,000 Israelis (49,000 in Israel and 6,000 settlers in the West Bank), 62,000 Palestinians, 247,000 registered Jordanians and an estimated 250,000 foreign workers in Jordan originating mainly from Egypt, Iraq, and recently from Syria.

The rehabilitation of the lower part of the Jordan River has been a central aim of WEDO/EcoPeace's work since its establishment in 1994. Through education and advocacy campaigns, major research, and regional rehabilitation efforts, some real changes have already been made. For instance, new sewage treatment plants have been constructed in Jordan, Israel, and Palestine, and will enable treatment of polluted wastewater flowing currently into the river. Earlier research conducted for WEDO/EcoPeace concludes that the lower part of the Jordan River will require 400-600 MCM of fresh water per year to reach an acceptable rehabilitation level.

The topographic nature of the area has the typical rift valley characteristic with drastic drops in elevation over short distances from the edges of the valley, and a more gently decline closer towards the Jordan River. Alongside the axe of the valley, the elevation drops from north to south. In the northern part of the valley the drop is almost $375 \mathrm{~m}$ over a distance of $10 \mathrm{~km}$. In the middle part of the valley this drop in elevation exceeds $500 \mathrm{~m}$ over a distance of $9 \mathrm{~km}$. In the very south, this drop reduces to $100 \mathrm{~m}$ over a distance of $8 \mathrm{~km}$. An overview of the topography of the Jordan Valley is provided in Fig. 2.1.

The study area has a total surface area of $2508 \mathrm{~km}^{2}$, most of which $(61.5 \%)$ consists of uncultivated land. A total of $803 \mathrm{~km}^{2}(32 \%)$ is used for agriculture and $89.6 \mathrm{~km}^{2}(3.6 \%)$ as built up area. An overview is provided hereafter (Table 2.1, Figs. 2.2 and 2.3).

The dominant soil types in the area are regosols, rendzinas, and serozems, which are mainly tertiary deposits, and to a lesser extend lithosols, all of them generally fertile. As a result, the majority of land in the area that can be provided with water is used for agriculture and horticulture.

\subsubsection{Water}

The lower part of the Jordan River originates at the Sea of Galilee and meanders along $200 \mathrm{~km}$ down to the Dead Sea through the Jordan Valley. The average annual rainfall in the study area and the wider region is shown below. It varies from over $500 \mathrm{~mm}$ per year in the north to less than $100 \mathrm{~mm}$ in the south close to the Dead Sea. With high temperatures and average dry conditions; the average annual evaporation is high, varying from 2150 to $2350 \mathrm{~mm}$ per year.

Historically the lower part of the Jordan River received about $600 \mathrm{MCM} / \mathrm{year}$ from Sea of Galilee in the north and about $470 \mathrm{MCM} / \mathrm{year}$ from the Yarmouk River in the 


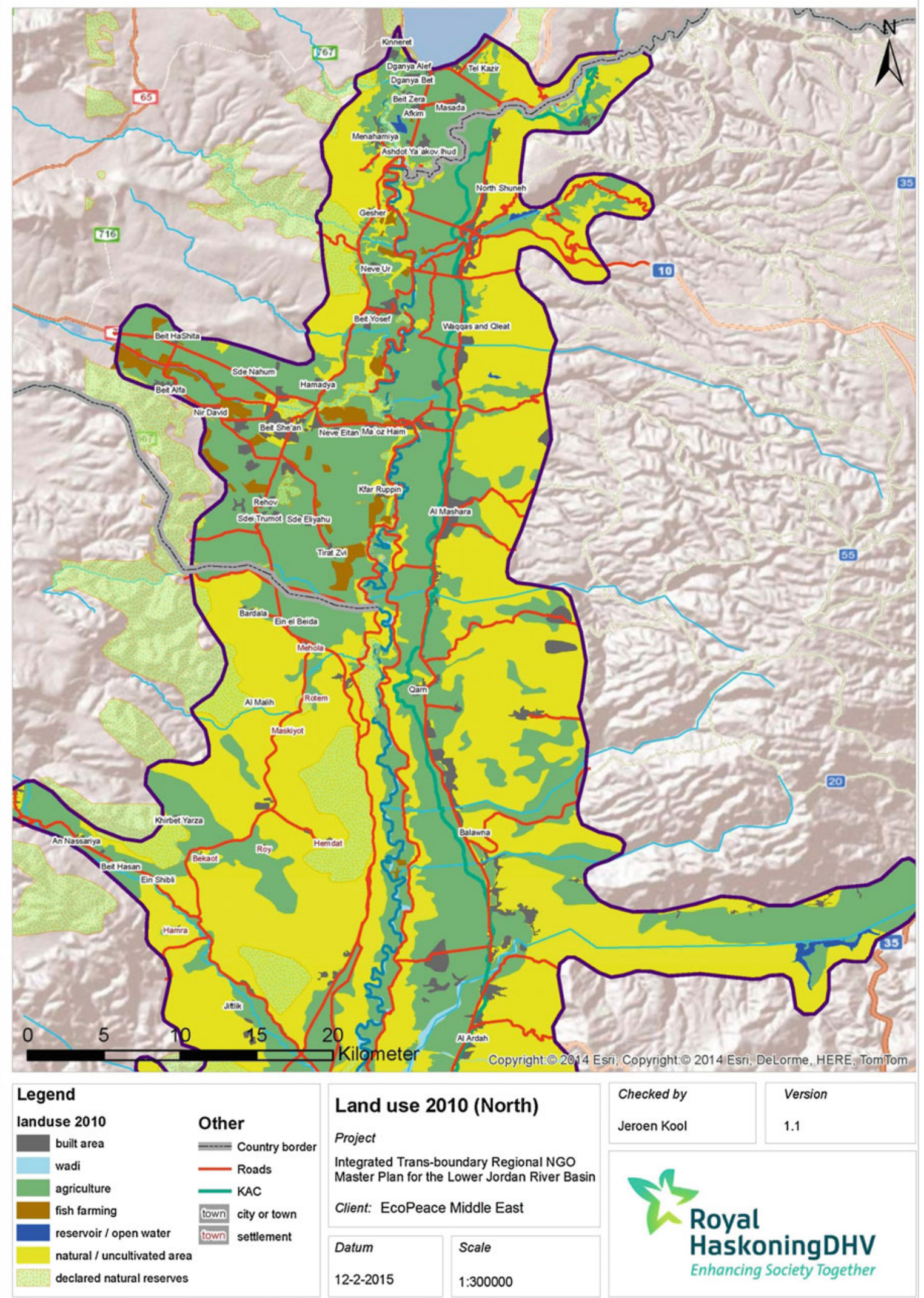

Fig. 2.1 Current land use of the northern part of the Jordan Valley 
Table 2.1 Land use in the study area

\begin{tabular}{l|l|l}
\hline Land use & Surface area in $\mathrm{km}^{2}$ & $\%$ \\
\hline Agriculture & 803.1 & 32 \\
\hline Built area & 89.6 & 3.6 \\
\hline Fish farming & 22.6 & 0.9 \\
\hline Natural/Uncultiva & $1,543.50$ & 61.5 \\
\hline Reservoirs & 6.4 & 0.3 \\
\hline Wadi's & 43.2 & 1.7 \\
\hline Grand total & $2,08.40$ & 100 \\
\hline
\end{tabular}

northeast. With some addition inflow from the Zarqa River and nine other streams from the East Bank, the lower part of the Jordan River had an outflow into the Dead Sea of about 1200-1300 MCM/year.

Since the 1950s the water from the river has been increasingly diverted by Israel, Jordan, and Syria for domestic water supply and the development of the agricultural sector in the region (Fig. 2.4).

The water is diverted mainly by the Israeli National Water Carrier taking water from Sea of Galilee, and through the development of various dams in Syria and dams and canals in Jordan, including the Unity Dam in the Yarmouk river on the border between Jordan and Syria, the King Talal Dam in the Zarqa Basin, and the King Abdullah Canal running east and parallel to the river. Today the outflow into the Dead Sea is about 70-100 MCM/year or less (Fig. 2.5).

The northernmost section of the river is regulated in Israel by the Deganya Dam at the Sea of Galilee, and the Alumot Dam, about $2 \mathrm{~km}$ further downstream. During the last 50 years, no fresh water was discharged into the LJR, other than during flood years. In 2013 a new Israeli policy was implemented where increased fresh water levels would be released, starting with $9 \mathrm{MCM} / \mathrm{year}$ and growing to $30 \mathrm{MCM} / \mathrm{year}$ in 2016. During the winter season, the river may occasionally contain flood waters after heavy rainfall in the upper catchment of the Jordan Valley, as happened during the early months of 2013.

The Jordan River has become polluted due to inflow of untreated wastewater and saline water which was diverted into the river from springs west of the Sea of Galilee through the Saline Water Carrier. As of late 2014 a secondary level wastewater treatment plant has been completed on the Israeli side, releasing now-treated wastewater into the river. By the end of 2015 the plant will be upgraded to tertiary level and all wastewater will be reused for agriculture and replaced by fresh water from the Sea of Galilee. On the Jordanian side, most of the wastewater locally generated is not treated and discharged directly into the groundwater, Wadis, and eventually the Jordan River. Here the exception is the newly built North Shuna wastewater treatment plant. However, more
WWTPs are needed on the Jordanian side. This is also the case for most of the wastewater generated by the Palestinians (with the exception of the newly built WWTP in Jericho) and Israeli Settlements in the West Bank part of the valley, be it that the population there is considerably smaller than in the East Bank. Finally, the Jordan River is polluted by the flushing of fishponds in Israel about twice a year. This water is polluted by fish excrement and antibiotic components usually added to the fish ponds.

The groundwater system in the Jordan Valley consists of a shallow aquifer system from the Plio-Pleistocene ages which overlays the upper sub-aquifer system of the Upper Cenomamian and Turonian ages and the deep confined aquifer of the Lower Cenomamian age. The groundwater resources are particularly important for supply of the West Bank and the southern parts of the East Bank.

The aquifers are subject to increasing salinity levels, particularly in the south, mainly as result of over-exploitation and up-coning of deep brines that flow through the Jordan Rift Fault system. They are also affected by contamination of agricultural return flows and sewage effluents. An overview of the main groundwater aquifer systems in the region is given in Fig. 2.6.

The current low flow levels and bad water quality of the Lower part of the Jordan River have severe impacts on the area's unique ecosystem including the approximate 500 million migratory birds that migrate through the Jordan Valley twice a year (Fig. 2.7).

The King Abdullah Canal (KAC) on the east side parallel to the Lower part of the Jordan River was built in three phases between 1957 and 1966. It captures mainly runoff from the Yarmouk River, the Mukheibeh Wells and several wadis. The canal plays a central role in Jordan's agricultural development as it supplies irrigation water via pumping stations to farmers in an area of 400-500 ha. In addition, Amman receives about $50 \mathrm{MCM} /$ of water per year from KAC. This transfer constitutes around one third of water supplied to Amman and also corresponds to one third of the water diverted to KAC. The amount of water pumped from KAC to Amman is likely to increase as Jordan purchases more water from Israel following the signing of a $2015 \mathrm{MoU}$ on water trade.

\subsubsection{Climate Change}

Climatically, the Jordan Valley is characterized by hot dry summers and mild wet winters, becoming progressively drier moving southward through the valley towards the Dead Sea. Climate change impacts are likely to intensify the water supply-related problems in the Jordan Valley. Table 2.2 provides an overview of the climate characteristics of the Jordan Valley. 


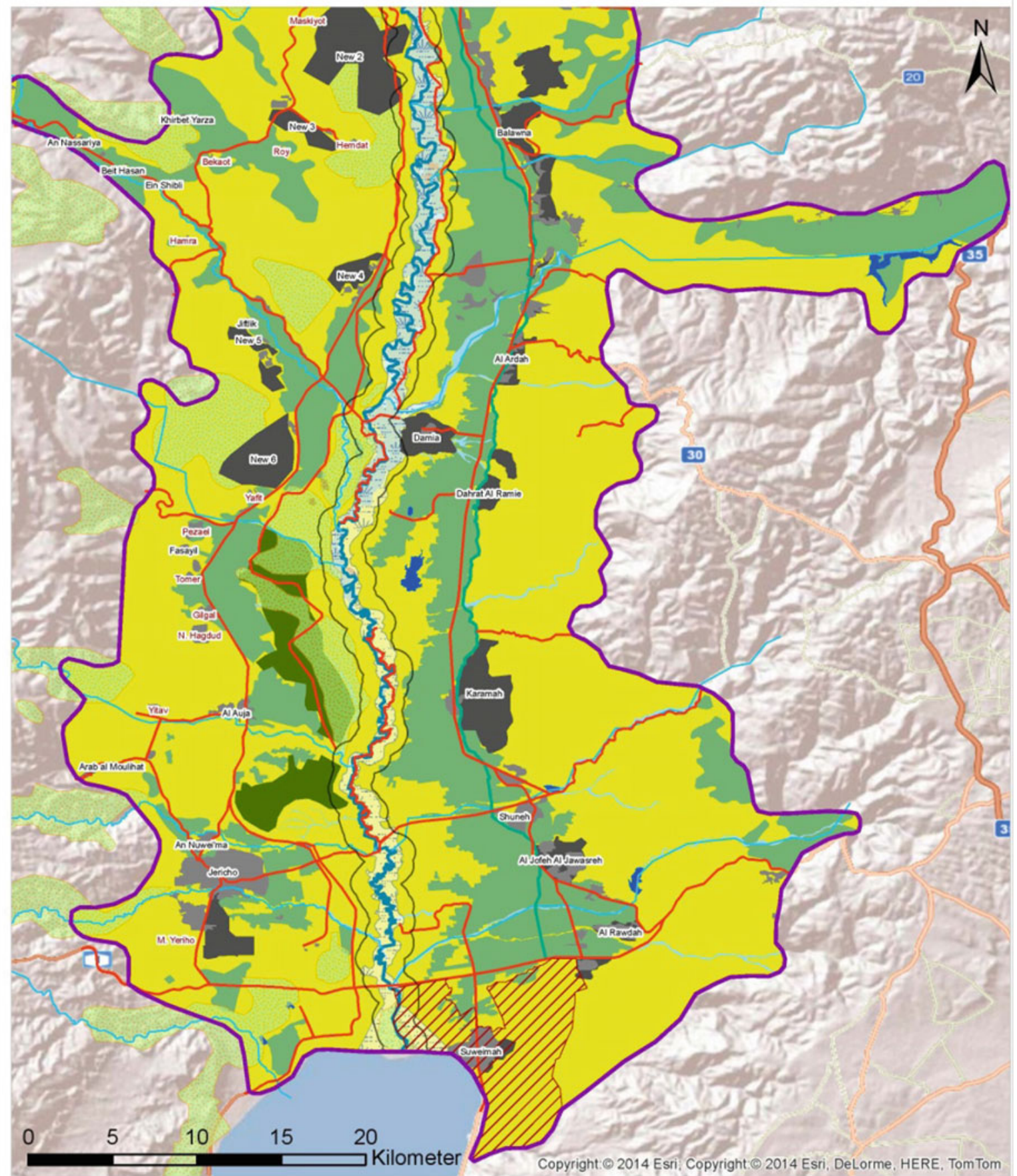

\begin{tabular}{|c|c|c|}
\hline \multicolumn{3}{|l|}{ Legend } \\
\hline landuse 2010 & Landuse 2050 and important areas & Other \\
\hline built area & agricumture expansion & $=$ Country border \\
\hline wadi & urbanisation & - roads \\
\hline agriculture & project boundary & KAC \\
\hline fish farming & declared natural reserves & rivers and streams \\
\hline reservoir / open water & winer river flood plains & Lower Jordan River \\
\hline natural/ uncultivated area & \begin{tabular}{|l}
$\square$ \\
\end{tabular} $\mathrm{km}$ zone river & town city or town names \\
\hline & $\nabla /$ sigma study area & town settement names \\
\hline
\end{tabular}

\begin{tabular}{l|l} 
Datum Scale &
\end{tabular}

\begin{tabular}{l|l}
$12-2-2015$ & $1: 300000$
\end{tabular}

\section{Future land use 2050 (South)}

Project

Integrated Trans-boundary Regional NGO

Master Plan for the Lower Jordan River Basin

Client: EcoPeace Middle East

Fig. 2.2 Current land use of southern part of the Jordan Valley south 


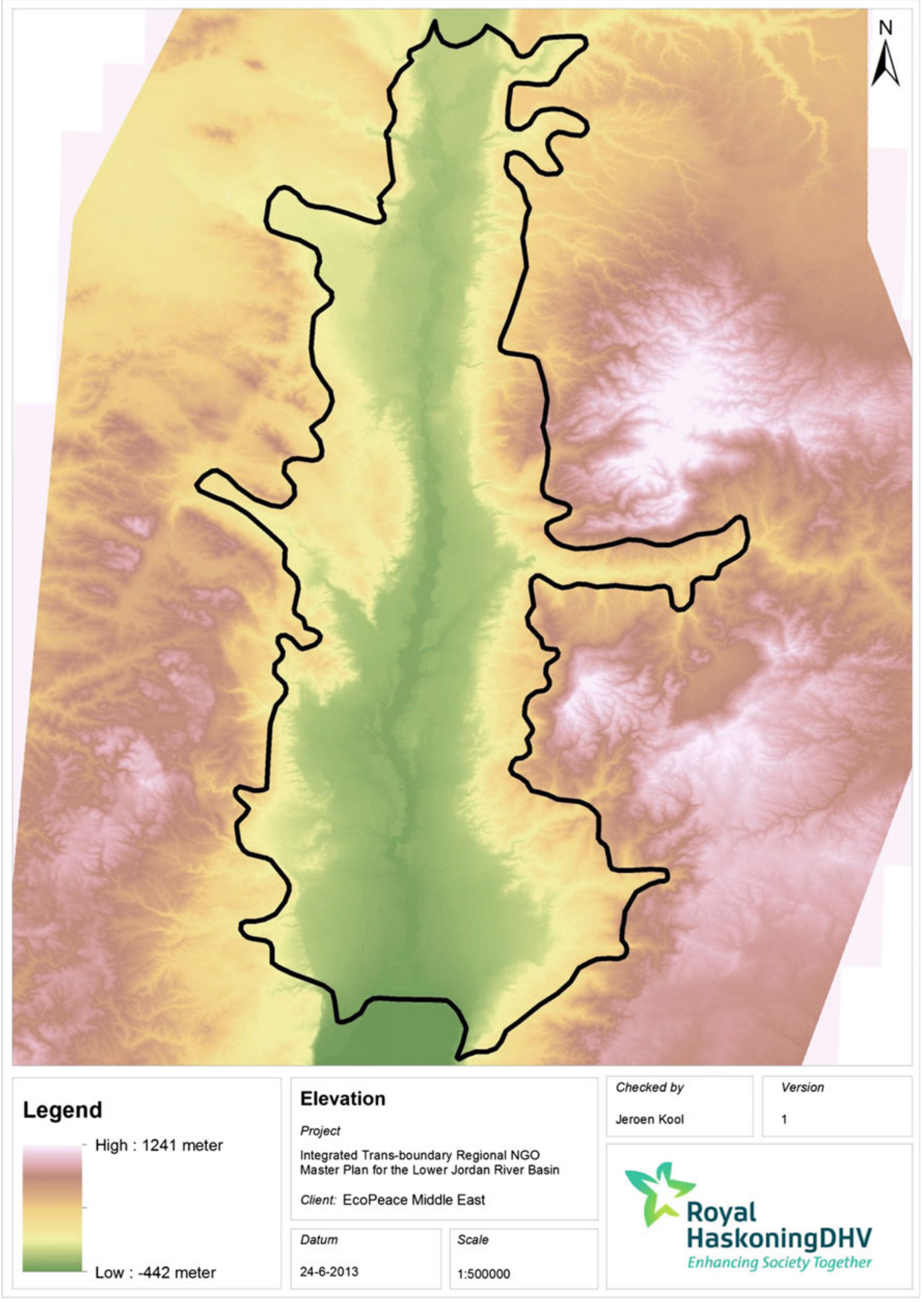

Fig. 2.3 Topography of the Jordan Valley 
Fig. 2.4 The Jordan River

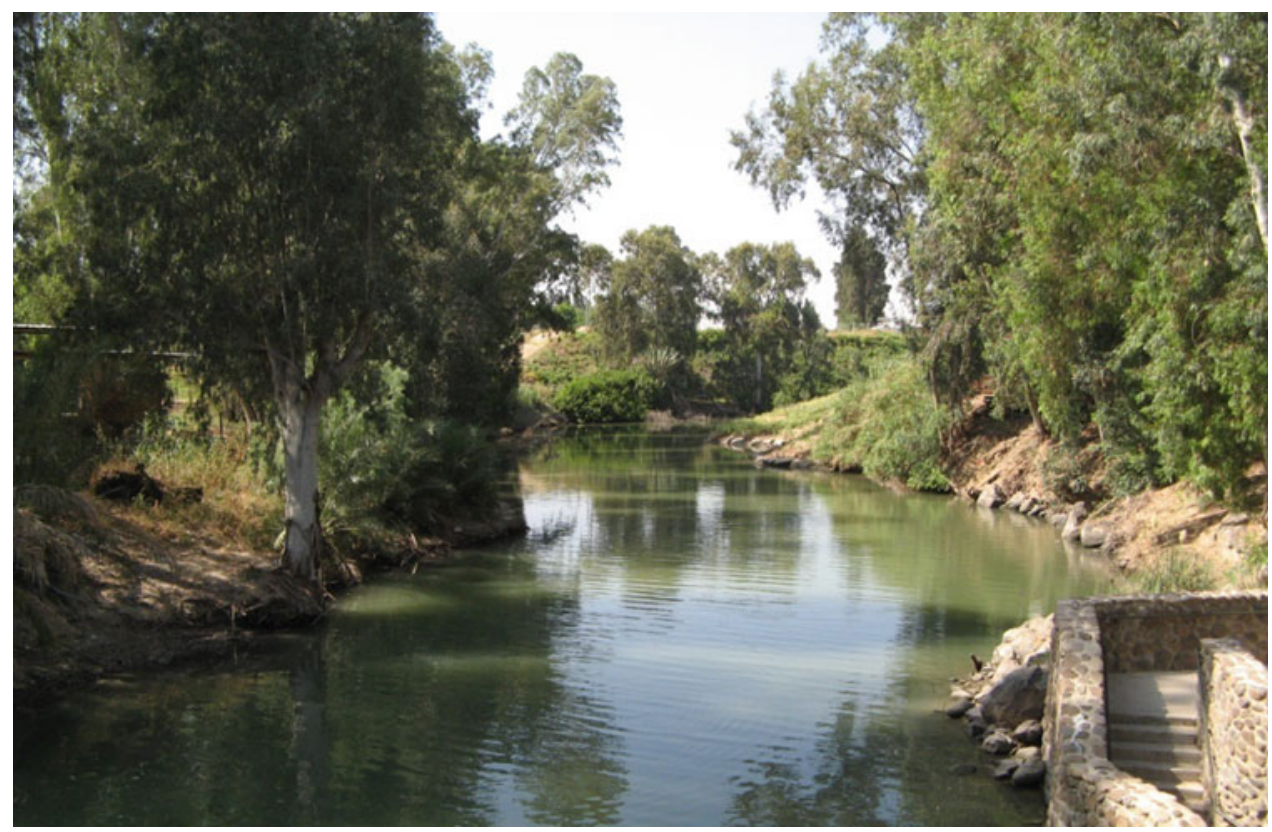

Analysis of the impacts of climate change has been made for the wider Middle East Region by GLOWA (2008). Overall, these impacts include a foreseen reduction in local annual water resources with a maximum of $20 \%$ by 2050 and increasing temperatures and related surface water evaporation rates. A summary of the related impacts is proved below.

The northern part of the East Bank of the Jordan Valley in Jordan will be impacted most negatively by climate change, with a foreseen substantial reduction of annual and winter rainfall, although summer rainfall will increase slightly. The southern part of the East Bank will see a slight improvement of rainfall conditions, both annually as during the summer (Table 2.3).

\subsubsection{Ecosystems}

Figure 2.8 provides the "Normalized Difference Vegetation Index" for the Jordan Valley. This index has been calculated on the basis of satellite images, wherein the green(er) parts represent high(er) vegetation densities, or higher concentrations of natural photosynthesis processes.

The Jordan Valley is characterized by a wide range of bio-climatological and physical conditions, and its location at the crossroads of climatic and botanic regions endows the area with a rich variety of plant and animal life. For example, a total of 20 species of large mammals have been recorded in the valley. Among them, four species are considered at risk according to the IUCN Red List of Threatened Species. Moreover, 18 bat species were found along the Jordan Valley, two of them are considered endangered or threatened on a global scale.
The area around the southern end of Sea of Galilee is characterized as a Mediterranean zone. On the Jordanian side of the Jordan Valley, the Mediterranean zone stretches about $150 \mathrm{~km}$ further south than on the western counter part in Israel. Mediterranean vegetation is typical for those areas of the mountain range which receive an annual precipitation of $350 \mathrm{~mm}$ or more. These areas have been intensively managed by mankind since historical times, and large areas are cultivated fields or orchards. Southward, down to the northern limit of the southern Jordan Valley, the environment is Irano-Turanian. Rainfall gradually decreases here from an average of $400 \mathrm{~mm}$ in the north to about $200 \mathrm{~mm}$ at the southern end. In Jordan, this zone is often a transition between the Mediterranean and desert areas.

Around spring and autumn, the Jordan Valley serves as an important migration route for some 500 million birds flying between Eastern Europe, Western Asia, and Africa. Some of these species are currently considered threatened on a global scale by the IUCN and Birdlife International. Most importantly, large portions, or even entire bird populations, pass through the Jordan Valley as it serves as a bottleneck for bird migration. A good example is the White Stork, of which some 500,000 pass through the region twice yearly. This quantity amounts to almost the entire Eastern European population.

A total of 15 native freshwater fish species exist in streams and springs in the Jordan Valley. In addition, some 12-13 native freshwater fish species can be found in the Yarmouk River systems. Furthermore, several alien species have been introduced into the water systems of the Jordan Valley. 
Fig. 2.5 Lower part of the Jordan River and its main tributaries

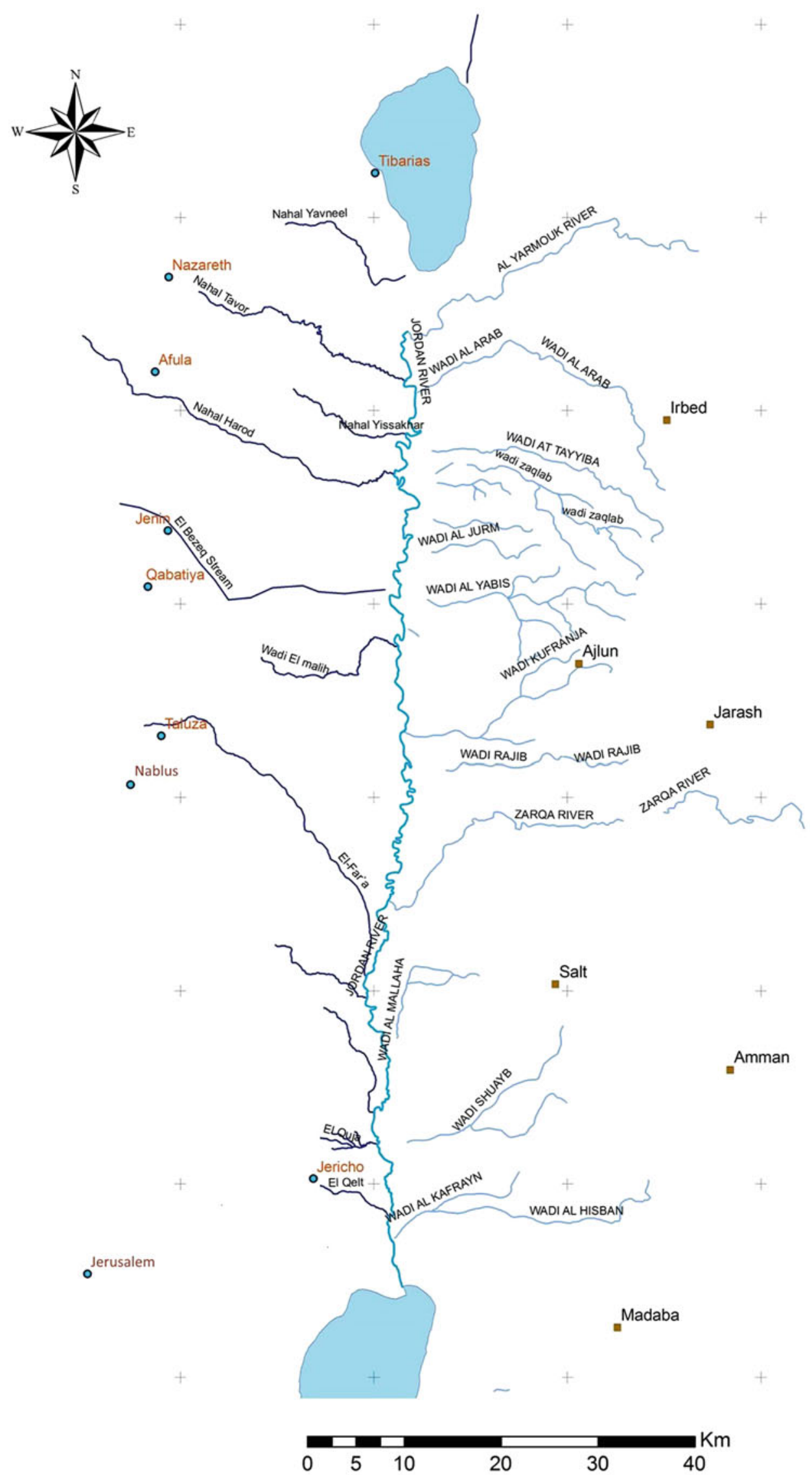




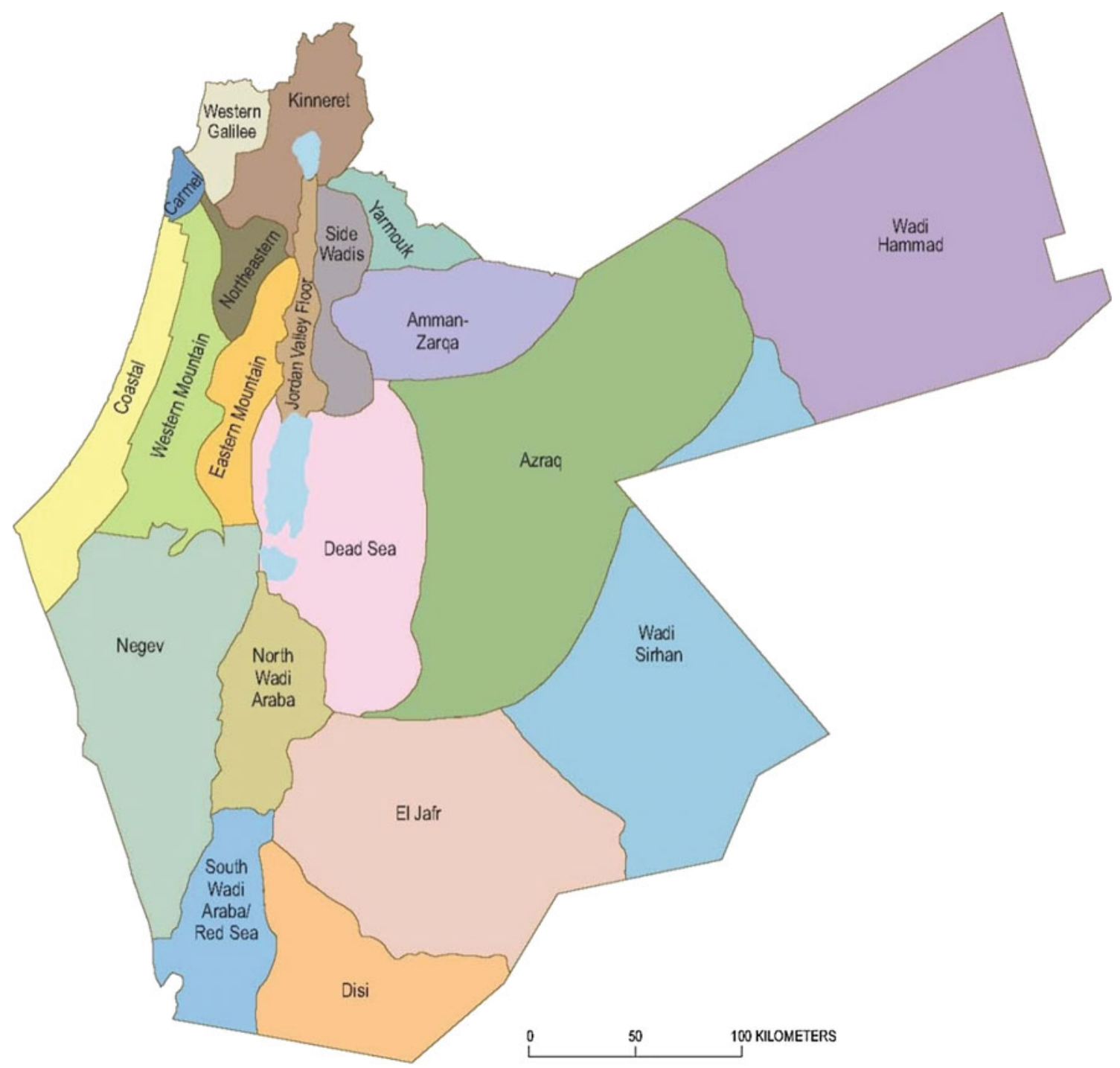

Fig. 2.6 Groundwater aquifer systems in the region (ref: EXACT-ME)

Fig. 2.7 Arab Dam

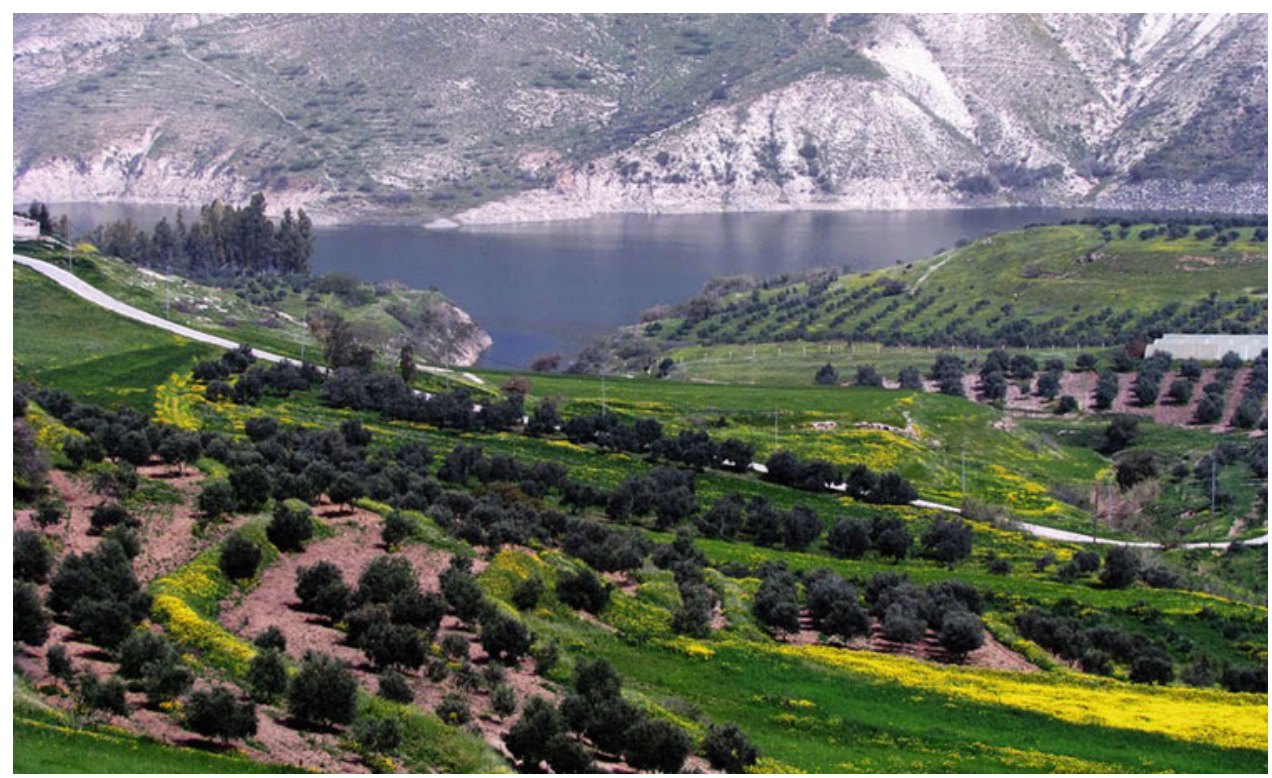


Table 2.2 Climate characteristics relevant for the Jordan Valley

\begin{tabular}{l|l|l|l}
\hline Climate characteristic & Type 11 (north) & Type 9 (middle) & Type 8 (south) \\
\hline Annual temperature & $18-20^{\circ} \mathrm{C}$ & $18-20^{\circ} \mathrm{C}$ & $18-20^{\circ} \mathrm{C}$ \\
\hline Summer temperature & $21-27^{\circ} \mathrm{C}$ & $21-27^{\circ} \mathrm{C}$ & $21-27^{\circ} \mathrm{C}$ \\
\hline Winter temperature & $10-12^{\circ} \mathrm{C}$ & $10-12^{\circ} \mathrm{C}$ & $10-12^{\circ} \mathrm{C}$ \\
\hline Annual precipitation & $>600 \mathrm{~mm}$ & $70-100 \mathrm{~mm}$ & $<70 \mathrm{~mm}$ \\
\hline Summer precipitation & $<10 \mathrm{~mm}$ & $10-30 \mathrm{~mm}$ & $<10 \mathrm{~mm}$ \\
\hline Winter precipitation & $>300 \mathrm{~mm}$ & $<30 \mathrm{~mm}$ & $<30 \mathrm{~mm}$ \\
\hline
\end{tabular}

Table 2.3 Climate change related impacts to the Jordan Valley

\begin{tabular}{l|l|l|l}
\hline $\begin{array}{l}\text { Jordan } \\
\text { Valley } \\
\text { regions }\end{array}$ & Annual precipitation & Summer precipitation & Winter precipitation \\
\hline $\begin{array}{l}\text { Jordan } \\
\text { North) }\end{array}$ & $\begin{array}{l}\text { Substantial reduction of annual rainfall in the } \\
\text { coming decades from more than } 600 \mathrm{~mm} \\
\text { historically to less than } 100 \mathrm{~mm}\end{array}$ & $\begin{array}{l}\text { Slight increase of summer } \\
\text { rainfall from less than } 10 \mathrm{~mm} \\
\text { historically to maximum } \\
30 \mathrm{~mm}\end{array}$ & $\begin{array}{l}\text { Substantial reduction of winter rainfall in the } \\
\text { coming decades from more than } 300 \mathrm{~mm} \\
\text { historically to about less than } 30 \mathrm{~mm}\end{array}$ \\
\hline $\begin{array}{l}\text { Jordan } \\
\text { (South) }\end{array}$ & $\begin{array}{l}\text { 8-9 Slightly increase of annual rainfall from } \\
\text { historically less than } 70 \mathrm{~mm} \text { to about 70- } \\
100 \mathrm{~mm}\end{array}$ & $\begin{array}{l}\text { Slightly increase of summer } \\
\text { rainfall from less than } 10 \mathrm{~mm} \\
\text { historically to maximum } \\
30 \text { mm }\end{array}$ & $\begin{array}{l}\text { No change in winter rainfall, which remains to } \\
\text { be less than 30-70 mm }\end{array}$ \\
\hline Israel & $\begin{array}{l}\text { No change in average annual rainfall, which } \\
\text { remains more than 600 mm }\end{array}$ & $\begin{array}{l}\text { No change in summer } \\
\text { rainfall, which remains to be } \\
\text { less than } 10 \text { mm }\end{array}$ & $\begin{array}{l}\text { No change in winter rainfall, which remains } \\
\text { more than 300-600 mm }\end{array}$ \\
\hline Palestine & $\begin{array}{l}\text { Gradual shift southwards of more annual } \\
\text { rainfall (from less than 70 to more than } \\
600 \mathrm{~m} \text { ) with exception of the Jordan Valley } \\
\text { itself, which remains very dry }\end{array}$ & $\begin{array}{l}\text { No change in summer } \\
\text { rainfall, which remains to be } \\
\text { less than } 10 \mathrm{~mm}\end{array}$ & $\begin{array}{l}\text { Gradual shift southwards of more winter } \\
\text { rainfall (from less than 30-70 more than 300- } \\
600 \text { m) with exception of the Jordan Valley } \\
\text { itself, which remains very dry }\end{array}$ \\
\hline
\end{tabular}

During the last century, the area has undergone major developmental processes with substantial impacts on the local nature and ecology. Those processes include establishment of new communities and infrastructure, new industrial facilities, and transformation of natural land into agriculture land. Excessive pumping has caused groundwater depletion, as well as flow reductions in natural springs.

The lower part of the Jordan River has undergone severe alternation due to diversion of freshwater and inflow of polluted water. Moreover, floods were once part of the natural flow regime in the lower part of the Jordan River until the construction of Deganya Dam in 1932. These floods were essential in shaping the river meanders, flushing fine sediment, and creating a healthy, functioning ecosystem. As a result of the dam, aquatic habitats have deteriorated, accompanied by a decrease in macro-invertebrate fish populations and vegetation diversity. Today the river vegetation is dominated by halophytic plants, rather than the natural vegetation that disappeared over large areas.

An analysis of the environmental flow requirements of the lower part of the Jordan River indicates that the physical characteristics of the flow are the most important ecological factor for enabling macro-invertebrates. Less water in the LJR caused changes to the stream channel, resulting in a narrower and more canalized river ecosystem. Less water has also resulted in much slower velocities, reducing the number of habitats dependent on high flows, such as falls, cascades and rapids. Less water in the river also means less dilution of inflowing polluted water, such as brackish (ground) water or wastewater. This leads to higher pollution concentrations in the river stream. As a result, the ecology of the river is now reduced to pockets of high resistant and medium-to-slow velocity habitats.

Reduction in water flows, and damming of the river and its tributaries resulted in smaller river sediment loads. Slower velocities carry far less sediment with smaller grain sizes. The formation of streamside water bodies, such as deserted meanders, stopped, and related habitats disappeared from the river's ecosystem, resulting in the loss of unique community compositions of both plant and animal species specifically adapted to these habitats. If healthy freshwater ecosystems are to be restored, it is important to address the natural flows around which flora and fauna can develop. Critical parameters in this respect are the quality of 


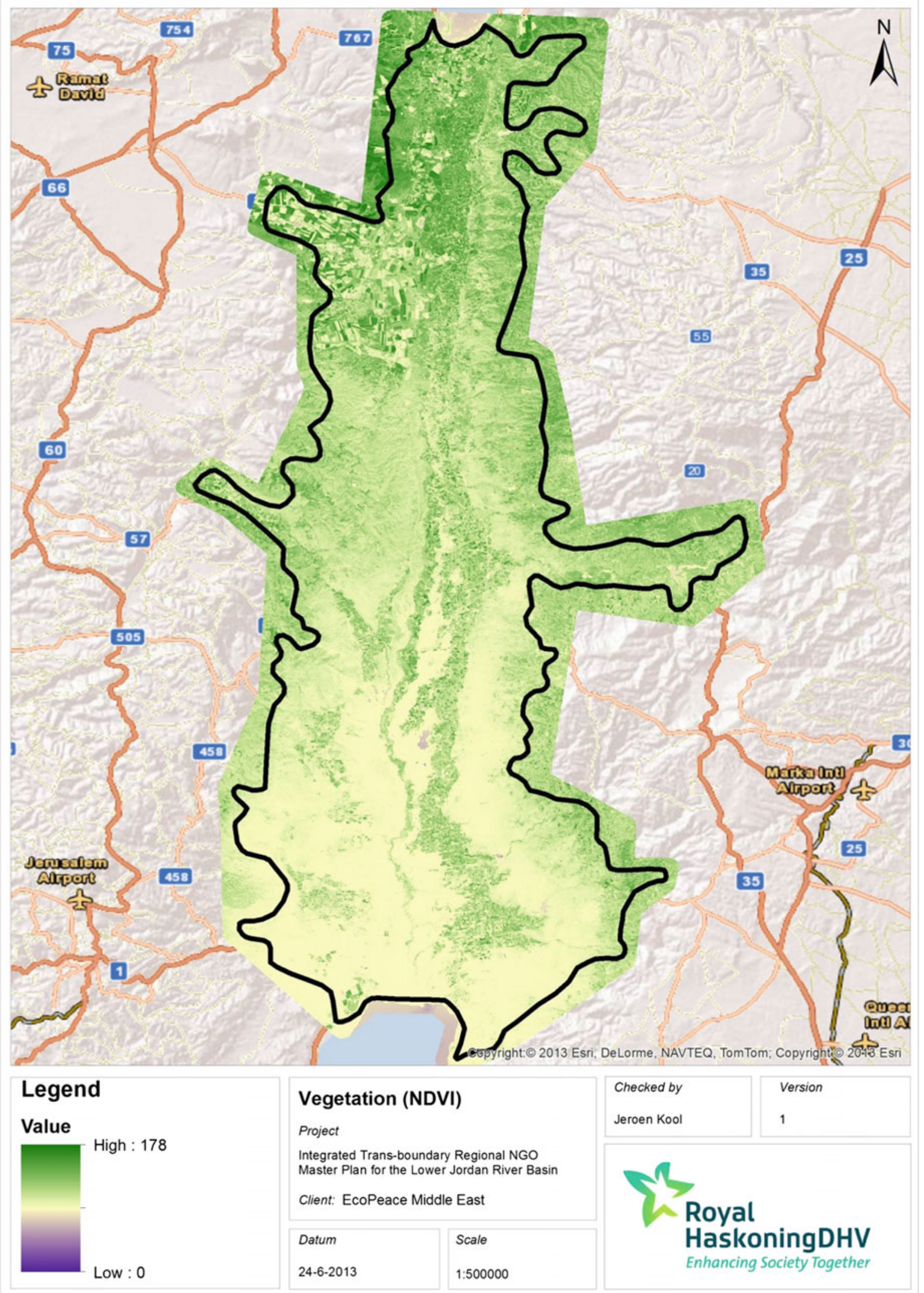

Fig. 2.8 Vegetation index 
Table 2.4 Current threats for ecosystems in the Jordan Valley

\begin{tabular}{|c|c|c|}
\hline No. & Threat & Root cause \\
\hline \multirow[t]{5}{*}{1} & \multirow[t]{5}{*}{ Fragmentation of habitats } & - Agricultural encroachment \\
\hline & & - No land use strategies, which were implemented and monitored \\
\hline & & - No guideline policies on conservation with development agencies \\
\hline & & - Unregulated urban and infrastructure expansion \\
\hline & & - No clearly mandated management agency \\
\hline \multirow[t]{4}{*}{2} & \multirow[t]{4}{*}{ Inappropriate agricultural development } & - Lack of comprehensive land use strategy \\
\hline & & - No conservation-orientated policies or extension services \\
\hline & & - Weak coordination between farmers and government agencies and local NGOs \\
\hline & & - High water demanding crops \\
\hline \multirow[t]{4}{*}{3} & \multirow[t]{4}{*}{ Water pollution } & - Excessive agrochemical use \\
\hline & & - Inadequate guidelines on use of agrochemicals \\
\hline & & - Minimal sewage treatment \\
\hline & & - Inadequate controls on industrial effluent \\
\hline 4 & Air pollution & - Inadequate controls on industrial emissions \\
\hline 5 & Solid waste & - Lack of treatment infrastructure \\
\hline \multirow[t]{2}{*}{6} & \multirow[t]{2}{*}{ Excessive hunting pressure } & - Inadequate enforcement of laws \\
\hline & & - Declining bird populations \\
\hline \multirow[t]{4}{*}{7} & \multirow[t]{4}{*}{ Excessive grazing pressure } & - Inadequate enforcement of \\
\hline & & - Regulations \\
\hline & & - Lack of grazing land \\
\hline & & - Limited alternative livelihoods \\
\hline \multirow[t]{3}{*}{8} & \multirow[t]{3}{*}{ Tree cutting } & - Inadequate enforcement of regulations \\
\hline & & - Limited fuel supplies for subsistence communities \\
\hline & & - Lack of alternative livelihoods \\
\hline 9 & Unregulated tourism development & - Inadequate planning and enforcement of regulations \\
\hline \multirow[t]{5}{*}{10} & \multirow[t]{5}{*}{ Over-extraction of water } & - Lack of coordinated strategy between government and users \\
\hline & & - Weak enforcement of regulations (EIAs) \\
\hline & & - Lack of water conservation technologies \\
\hline & & - High water demanding crops \\
\hline & & - No coordination between supply and demand \\
\hline
\end{tabular}

the water; the magnitude of the flow; the seasonable fluctuation of the flow; and the frequency, duration and variability of floods and droughts.

The Yarmouk and Jordan Rivers are also important for hosting many mammals in the vicinities of the river banks. Despite the deterioration of their natural habitat, many carnivores and other mammalian species managed to survive due to civilians' limited access to the area under military restrictions. However, the number of species in and around the Jordan River has diminished and requires further research. It might be possible, after thorough research, that some of the species could be reintroduced if the environmental conditions are restored.
The identified main ecological threats in the Jordan Valley and their causes are presented in Table 2.4.

The challenges to ecosystems and biodiversity protection in the Lower part of the Jordan River are particularly to create a stronger legal, management and information framework that enables adequate allocation, management and enforcement of nature protection.

Freshwater is the major environmental and socio-economic resource in the Jordan Valley, directly supporting all human activity, vegetation, and wildlife habitats and their associated productivity, with considerable inter-country variability. Freshwater sources are also the natural resource component most at risk since there is no economic substitute for the 
Fig. 2.9 Water snake in the lower part of the Jordan River

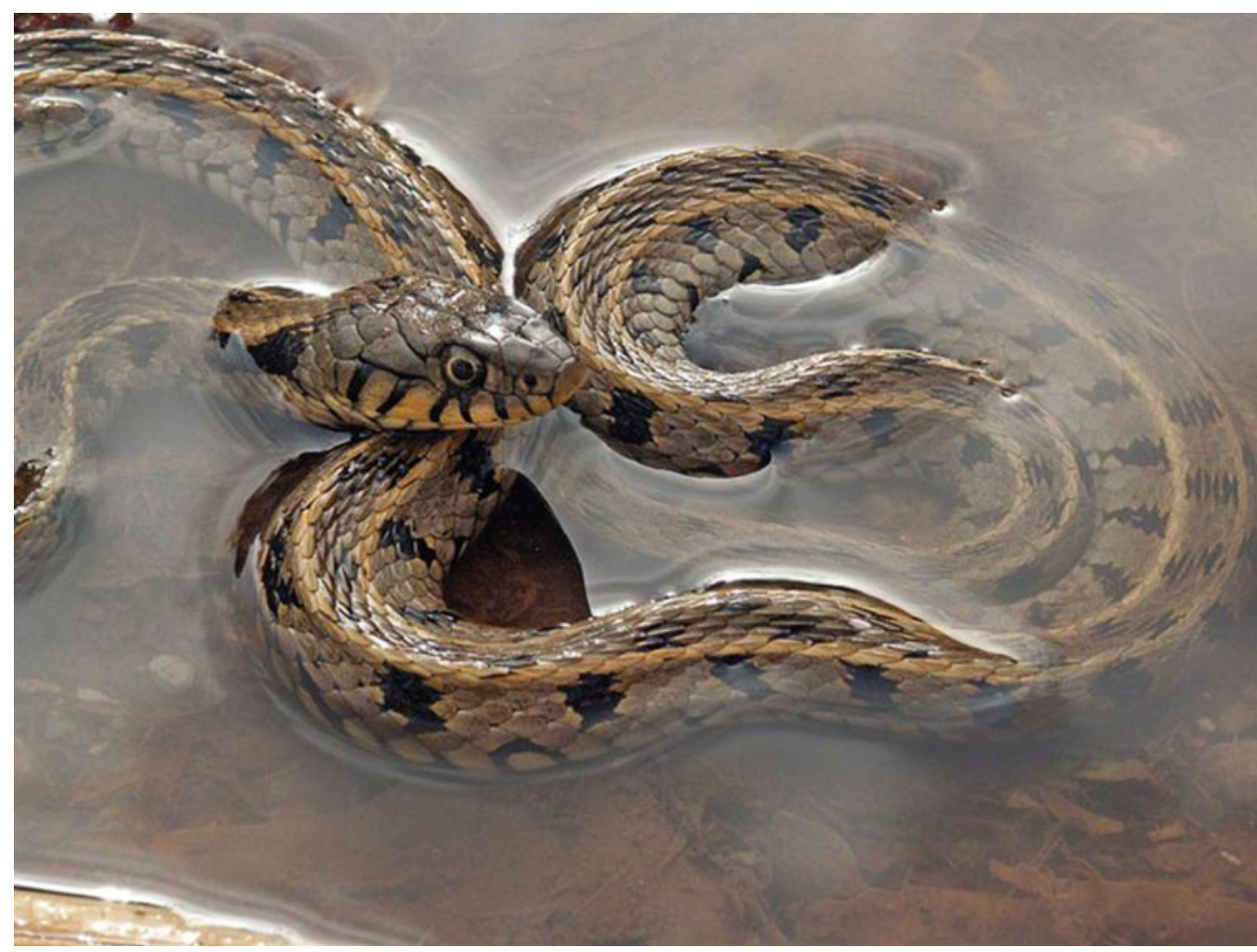

valley's watercourses and associated aquifers, which are also the final repository of human waste (Fig. 2.9).

Despite past impacts, the Jordan River still provides important habitats to wildlife and fish. This lowland riparian habitat has been identified by many national and international environmental agencies as the single most important habitat type in the region for avian species.

\section{Nature Reserves}

In the Western part of the Jordan Valley a total of 44 natural reserves and national parks have been assigned by Israel from Sea of Galilee to the Dead Sea. A total of 28 of these nature reserves are entirely located inside the project boundaries, while the areas of the rest are crossed by the project's boundaries. The total protected area north of Bezeq stream is $61 \mathrm{~km}^{2}$, while the total protected areas south of the Bezeq Stream as defined by Israel amount to $117.5 \mathrm{~km}^{2}$. The areas of the natural reserves and national parks north of Bezeq stream tend to be smaller than those in the Palestinian West Bank.

From a biological and wildlife diversity perspective, the most important nature reserves are the Valley's lower plain (the Zor), the Jordan Valley inland salt flats (sabkhas), and Wadi Auja. The two largest salt flats in the Valley contain rare plant species that are exclusive and need these extreme conditions in their life cycles. Other important nature reserves include Wadi al-Fasayil and Umm Zuka Ridge,
Wadi El Maliah, Wadi Fara'a, Wadi el-Fasayil, and Wadi Qelt. Some of these wadis are seasonal in nature, and others are partially perennial. From an ecological point of view, the most spectacular stream is Wadi Qelt (Figs. 2.10 and 2.11).

The Yarmouk River Valley border area between Israel and Jordan has been left largely undisturbed due to its strategic political location. As a result, it supports a wide variety of plant and animal communities typical of intact and less polluted river systems. It is proposed to allocate this area as a dedicated protection site (around $30 \mathrm{~km}$ ), because the area includes important woodlands and wildlife.

\subsubsection{Pollution Sources}

The major sources of pollution on the Jordan Valley include untreated wastewater and diversion of saline water into the valley; solid waste dumping; and pollution from agriculture, husbandry, and fishponds.

\section{Wastewater}

Untreated sewage water flowing in the Jordan Valley is one of the major pollution sources in the study area. The lower part of the Jordan River downstream of the Alumot Dam until 2014 contained high concentrations of Fecal Coliforms, indicating large sewage spills into the river system. Many 


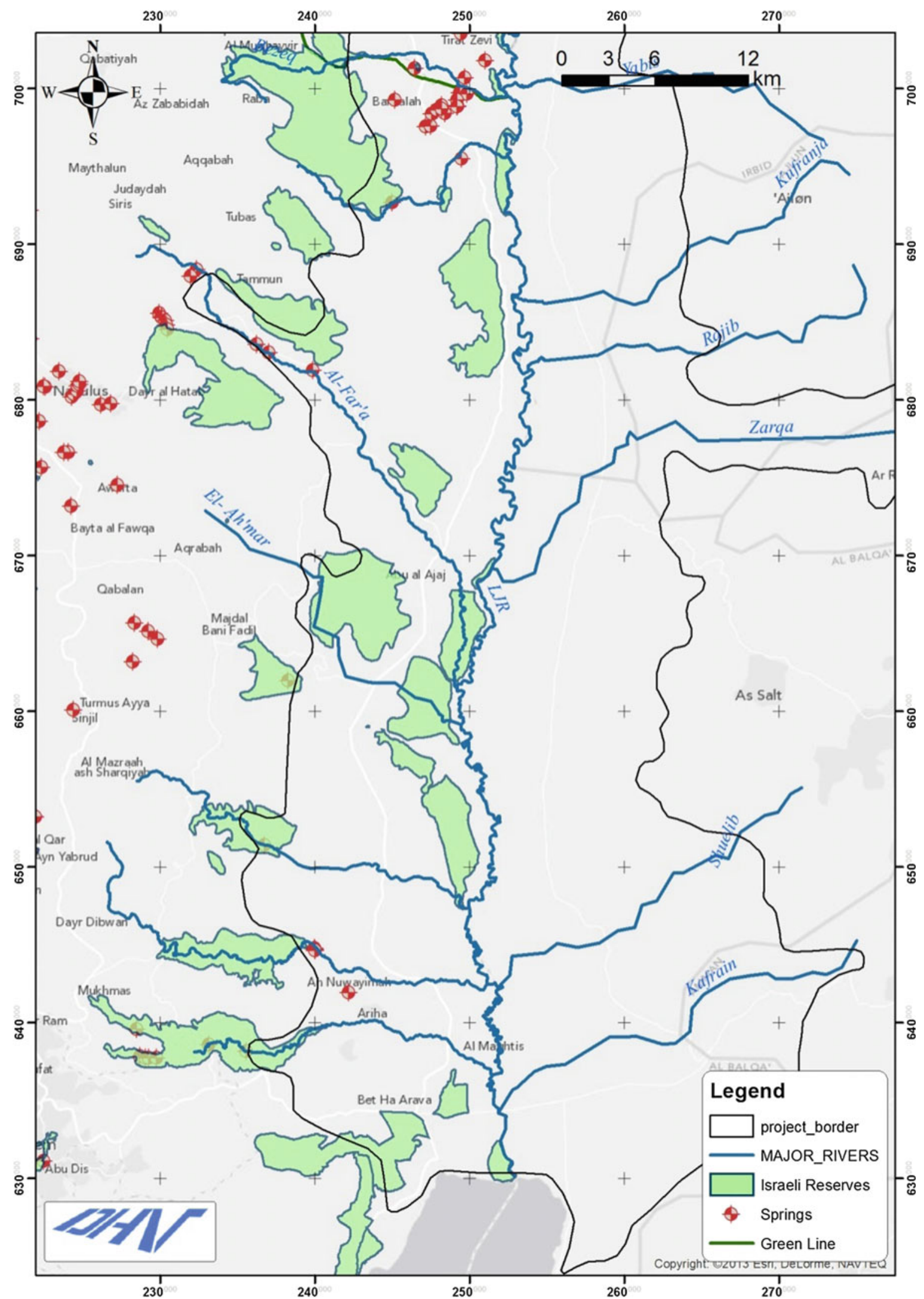

Fig. 2.10 Parks in the north part of the Jordan Valley 


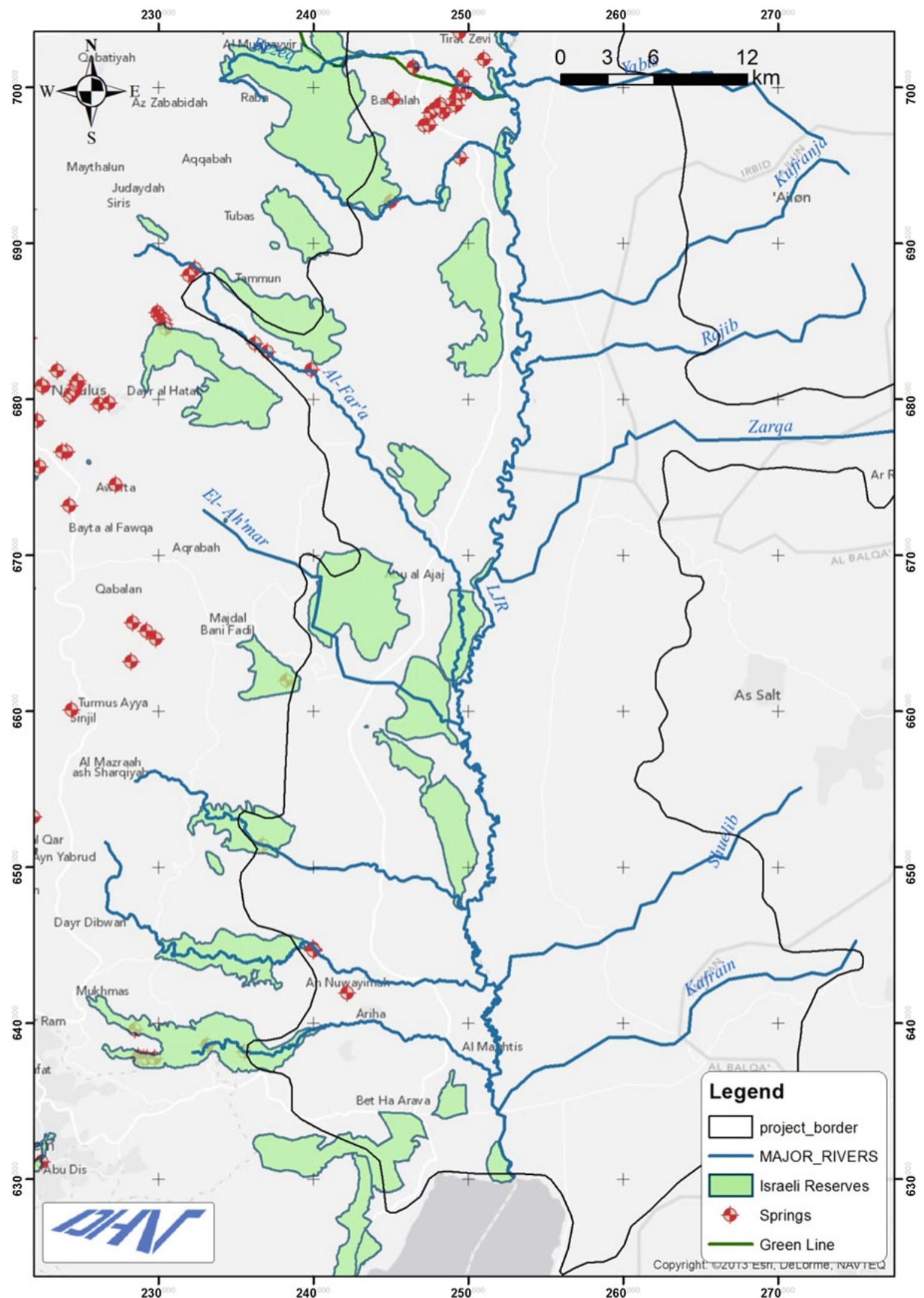

Fig. 2.11 Nature reserves and national parks in the southern part of the LJV (West Bank) 
communities in Israel, Jordan, and Palestine until recently discharged or are continuing to discharge their untreated or poorly treated sewage water directly or indirectly (through groundwater seepage) into the valley.

There are two wastewater treatment plants in Jordan which treat only a fraction of all generated wastewater in the valley. One of the plants is the Tal Al Mantah WWTP which started operations in 2005 and is located to the west of Deir Alla. This WWTP receives wastewater from the Deir Alla and South Shuna regions. Its maximum capacity is $400 \mathrm{~m} /$ day, and in 2013 it received about $320 \mathrm{~m} /$ day (365 m/day in 2012). In Jericho, a treatment plant and sewage collection network for the whole city is under construction. The majority of Jordanian and Palestinian towns and villages are presently left with no sanitation solution.

The Beit Shean regional WWTP is a primary and secondary treatment facility which has been in operation since October 2009. The Beit Shean WWTP is currently treating 3.8 million $\mathrm{m}^{3}$ of wastewater per year and its effluence is reused for agricultural purposes. Its influence originates mostly from Beit Shean (1.2 million $\mathrm{m}^{3} /$ year), twelve communities in the Valley of Spring Regional Council $\left(800,000 \mathrm{~m}^{3} /\right.$ year$)$, the Beit Shean industrial area (1.2 million $\mathrm{m}^{3} /$ year), and some tourist resorts $\left(600,000 \mathrm{~m}^{3} /\right.$ year). In the near future, the wastewater of the Gilboa Regional Council will also be treated there.

As of late 2014, a secondary level wastewater treatment plant was completed just south of the Sea of Galilee in Bitaniya, on the Israeli side, and is now releasing treated wastewater into the river. By the end of 2015, the plant will be upgraded to tertiary level and all wastewater will be reused for agriculture. A new desalination plant has also been scheduled in Bitaniya to treat saline water from the Saline Water Carrier (SWC). As such, local agriculture will receive high quality effluents, which will reduce the pressure on freshwater resources from the Jordan River and lead to a release of up to $30 \mathrm{MCM}$ into the Jordan River. There is continued discussion as to whether the brine of the desalination plant will be released into ponds near the Green Line or whether a pipeline will take the brine all the way to the Dead Sea. WEDO/EcoPeace is calling for the latter.

Wastewater collection and treatment in the Palestinian part of the study area was neglected for a long time since a higher priority is given to securing a safe water supply and protecting reliable resources for domestic use. In the study area, all the Palestinian communities lack wastewater collection networks and rely on cesspits for the disposal of wastewater, with the exception of Jericho which has a new central wastewater treatment plant, that was constructed with financing from Japan. Wadi Fara'a (Tirza stream), the largest stream in the West Bank, is partially polluted because of sewage water coming from the east part of Nablus. Most of this water is used for agriculture, infiltrated in the soil, or evaporated before it reaches the Jordan River. Large amounts of waste and litter end up in this Wadi as well. In the rainy season, the pollution flows further downstream into the Jordan Valley.

The Israeli settlements in the West Bank use mainly oxidation ponds or cesspits to dispose of their wastewater. The larger settlements are obliged by Israel to develop full scale wastewater treatment. Two related plants are foreseen for the settlements Fazael-Netiv HaGdud and Shdemot Mehola.

\section{Solid Waste}

Apart from the Israeli section of the study area, there is a lack of adequate sanitary waste disposal and treatment, both for domestic waste as well as industrial waste. Recycling and reuse of waste takes place in only very limited amounts. It is estimated that approximately 162,000 tons of municipal waste per year is generated in the Jordan Valley, including 120,000 tons in Jordan, 24,000 tons in Israel, and 18,000 tons in Palestine. Land filling is the most common waste treatment technique within the study area and, apart from Israel, this is mainly done without adequate soil and environmental protection measures. It is estimated that less than $10 \%$ of the waste, or 16,000 tons per year, is physically transported out of the valley area to be disposed of elsewhere.

Waste collection, transportation, and disposal in Jordan are handled by local municipalities. Sometimes, smaller municipalities combine forces into a Common Services Council. In the study area, the municipalities in the north cooperate within the Northern Joint Services Council. The Ministry of Municipal Affairs is responsible for providing municipalities and Common Services Councils with finance to provide these municipal services. The Ministry of Environment is responsible for policies and planning of the waste sector, and is currently (2014) in the process of developing a national waste management strategy based on principles of maximized recovery, reuse, and recycle, designed as a final solution the proximity principle (Fig. 2.12).

Solid waste collection fees today vary between about 14 and 20 JOD per year per household.

Collected waste in the Jordan Valley is brought to the Deir Alla dumpsite. This dumpsite is located $1 \mathrm{~km}$ from the Jordan River to the west of Deir Alla. The dumpsite is badly sited, as the location is close to a community and a groundwater reservoir which is used for drinking water. The dumpsite has no any facilities like lining or percolate collection. Waste water percolates directly into the groundwater and the Jordan River. 
Fig. 2.12 Deir Alla landfill

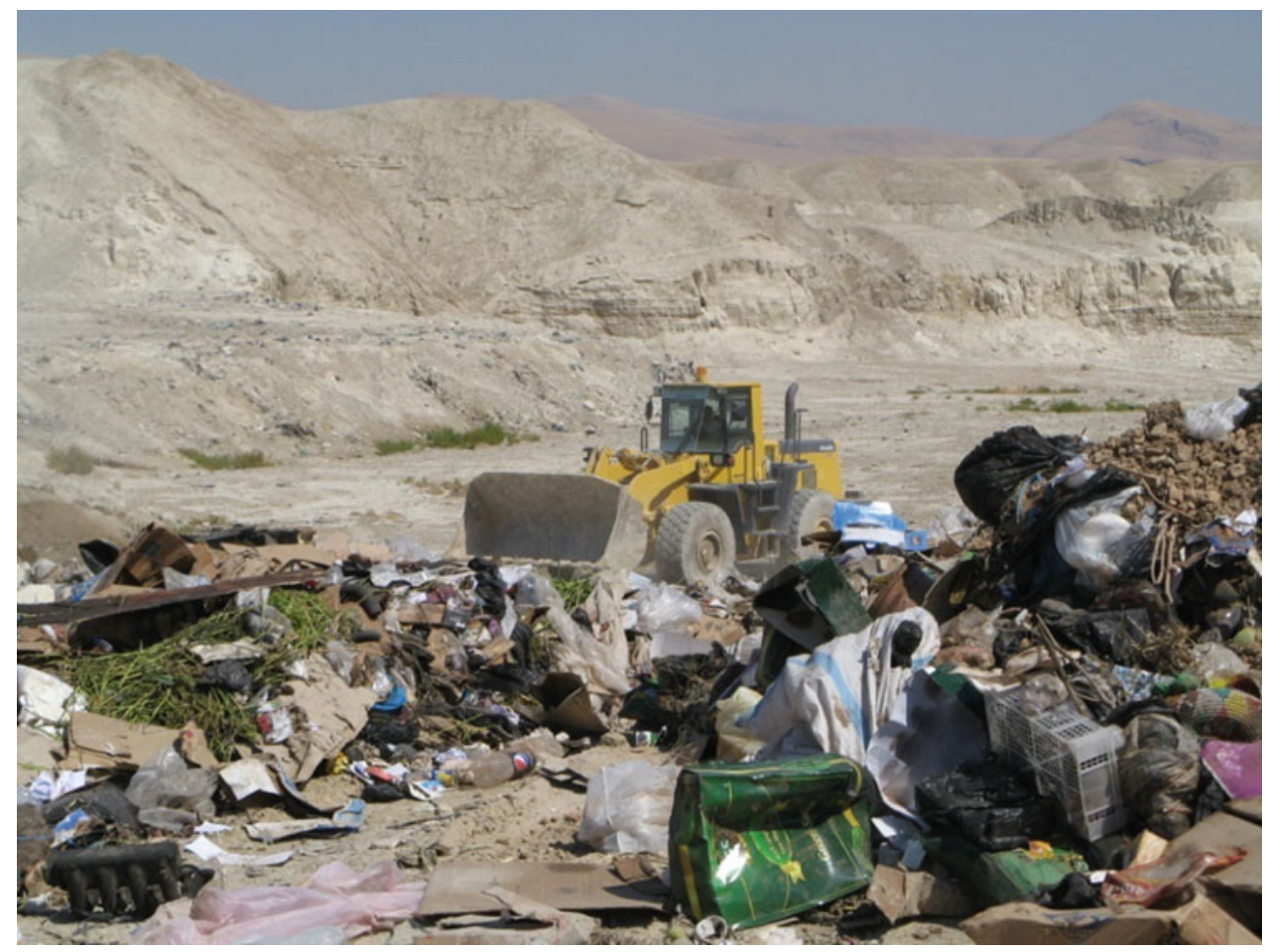

The Hagal landfill, north of Gesher, is the only authorized landfill in the Israeli part of the master plan project area. As an authorized landfill, it has all the required infrastructure and operations of a sanitary landfill, including a lining system, percolation water collection and treatment, landfill gas collection, and energy production. The landfill is owned by the private Israeli engineering firm TAHAL, and started operations in 1999. The total landfill volume is 3.5 million $\mathrm{m}^{3}$.

Palestinian waste is often dumped just outside the communities in the surrounding area. Luckily, as result of very dry conditions, the waste material dries out very quickly, so that leachate problems, smells, and pollution are limited. However, plastic waste remains and forms both a visual nuisance and a threat to animals. In the wet season, the littered waste causes a larger problem in terms of leachate, migration, and pollution. During floods, waste may end up in the Jordan River itself, even including waste that originated from the Eastern part of Nablus through Wadi Fara'a.

Agricultural waste makes up most of the waste generated in the Palestinian area. The only semi-controlled landfill in the Palestinian project area is the Tovlan landfill site, operated by the Israeli settlements. It is managed by the settlements belonging to the Bik'at Hayarden Regional Council. It receives waste from municipalities in Israel and from Israeli settlements in the West Bank. In the past it also received waste from some Palestinian communities, including Nablus city (80 tons/day), but this is no longer the case. In addition, plans have been developed to build a sanitary landfill for Jericho. Today there is a controlled dumpsite on the east side of Jericho. The dumpsite is not lined and its capacity is reaching its limits.

This all has a direct impact on public heath, groundwater quality, and eventually the water quality in the Jordan River. It is expected that less than $10 \%$ of waste, or 16,000 tons per year is physically transported out of the study area to be disposed of elsewhere.

\section{Agricultural Pollution}

Large parts of the study area are used for agriculture. Water is diverted from the Jordan River and its tributaries for irrigation, and return flows end up in the Jordan Valley groundwater or surface water. The agricultural return flows are generally polluted with phosphates, salt, nitrates, pesticides, and chemical fertilizers. Plant tissue and plastics used in agriculture contribute to the total quantity of solid waste produced in the study area, potentially causing pollution to the Jordan River and Jordan Valley. Furthermore remainders of unused pesticides and fertilizers may act as potential sources of pollution as well. Animal husbandry generates pollution sources in terms of manure (solid and fluid) and animal carcasses, which are potential threats for the environmental and public health.

Plastic waste in agriculture is generated from plastic covers of greenhouses, plastic mulch covers used for sun protection, and plastic pipes used in fields and greenhouses 
Fig. 2.13 Gesher fish farm

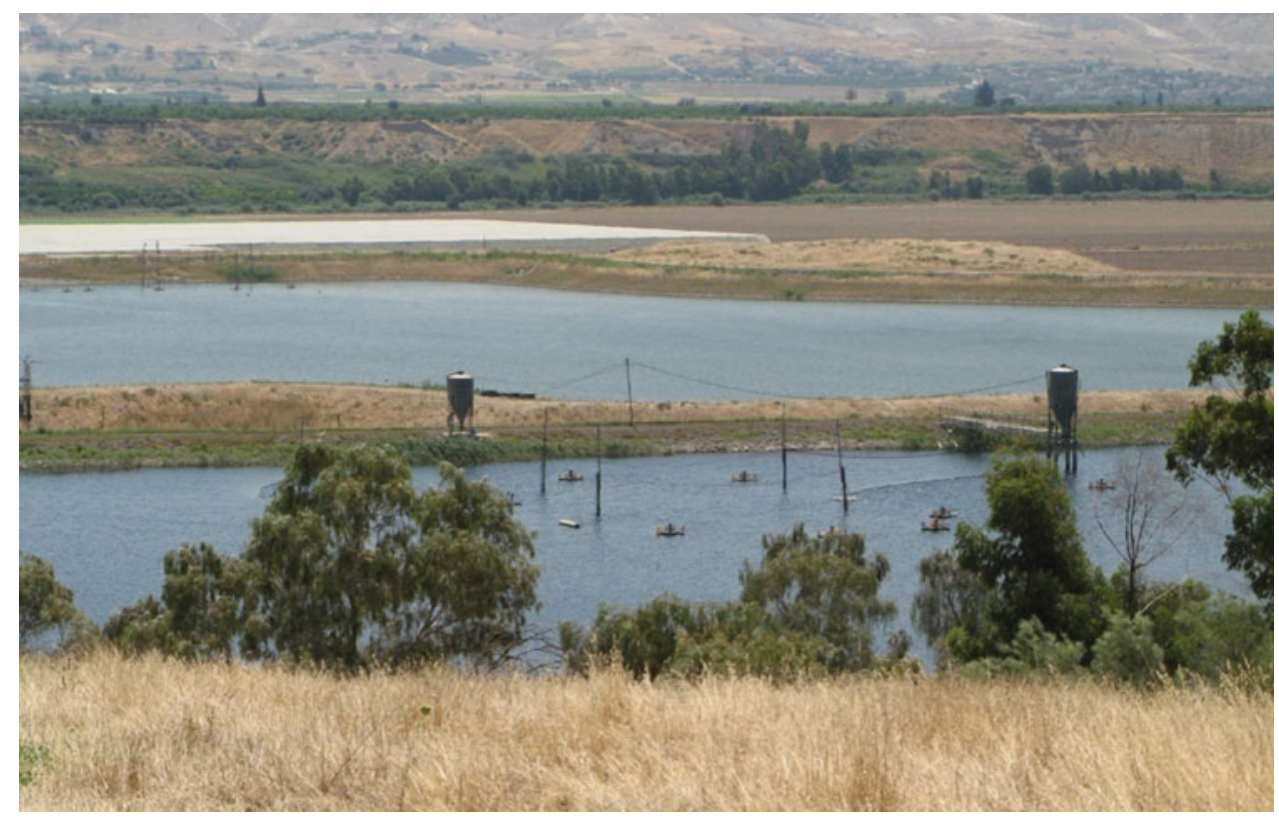

for irrigation. Most of the plastic is collected and sold to plastic recycling factories located mainly outside the Jordan Valley.

\section{Fish Ponds}

Fish farms are major water consumers in the Israeli part of our project area in the Jordan Valley. The total surface area of the fish farms in the region is approximately 2,000 ha. More than $90 \%$ of the fish ponds are concentrated around Harod Stream and in the Valley of Springs Regional Council. The main fish ponds in the Israeli part of the study area are the Gesher Fish Ponds, about 560 dunum in size; the Never Ur and Hamadia Fish Ponds, about 1100 dunum in total; and the Emek Hamaayanot Fish Ponds, about 10,000 dunum in total. The fish ponds are operated by AMWA, Gesher, Harod, and Neve Ur and Hamadia.

The Afikim fishponds will soon terminate operations and will be turned into a reservoir to store water from the new desalination plant to be built in Bitaniya for water from the Saline Water Carrier and for the effluent of Bitaniya WWTP. The brine, which remains after desalination, might be used in some of the fish farms. However, this would have a negative impact on the quality Jordan River (Fig. 2.13).

On average, a fish pond requires an inflow of water of $50,000-60,000 \mathrm{~m}^{3} / \mathrm{ha}$. This results in a total consumption of about $100 \mathrm{MCM} / \mathrm{year}$. These amounts have a large influence on the water balance in this part of the Jordan Valley. The water consumption is facilitated by a range of water reservoirs, which both serve as water storage and as fish cultivation capacity. Each reservoir is designated for a specific waste quality, making distinction between fresh water ( $<500 \mathrm{mg}$ Chlorine/l), treated waste water and saline water coming from, or mixed with local springs ( $>500 \mathrm{mg} \mathrm{Cl} / \mathrm{l})$. In this manner the fish farm can make an optimal mix for their production.

Evaporation increases the salinity of the water in the ponds. The discharged effluent water may have chloride concentrations varying between 2,000 and $4,000 \mathrm{mg} / \mathrm{l}$ depending on the concentrations of the inflow and the differences in operation. About $75 \%$ of the effluent is discharged between October and December; the rest of the effluent is discharged as late as February.

Fish farms consist of numerous small ponds often differing in age, depth, lining, etc. The water in the ponds is circulated several times between the ponds until it is discharged. The water may be recirculated for a period of 3 years before discharge. Since most of the ponds in the area were constructed without lining $(90 \%)$, water losses by percolation are estimated at $20-50 \%$ of the inflow. Most of this water finds its way to the Jordan River through groundwater. Another 40$50 \%$ is lost to evaporation and the rest is discharged back to the river as saline polluted effluent. This means that $10-40 \%$ of the inflow (so about 10-40 MCM/year) directly flows to the Jordan River as waste water.

\section{Land Mines}

The Hashemite Kingdom of Jordan ratified the Mine Ban Treaty in 1999. In accordance with its obligations under this international legal standard, Jordan has destroyed its stockpile of antipersonnel mines and has made steady progress to complete demining for its side of the entire Jordan Valley.

In the West Bank over 2,000 ha of land has been fenced by the Israeli military due to landmines-related risks. Some of the mine fields were laid by Jordan prior to 1967, along 
the 1949 Armistice border with Israel and surrounding old military bases. Other minefields were laid by Israel after 1967 around its own military bases and the current border with Jordan. Parts of agricultural and grazing land in the West Bank may still contain landmines as well. This causes risk of injury or death for civilians.

The marking and fencing of the landmine zones is poorly maintained and mine risk education is almost non-existent. Most of the casualties have been children. The Israeli military have started to remove mine fields in tourism-related areas. In Israel this includes Naharyim and Gesher, and around the Baptism site in the West Bank.

\subsubsection{Cultural Heritage}

The internationally recognized World Heritage values of the Jordan Valley are strongly related to its unique geographic features and its historic, religious, cultural, and archeological values. This section provides a short summary of the major cultural heritage sites in the Jordan Valley. A full assessment is provided in the Baseline Report (March 2014).

The Jordan Valley area attracted human habitation for thousands of years and is referred to as the most ancient inhabited area of human history. Archaeological sites date back to the pre-historic era. The remains of more than 20 successive human inhabited areas were found in Jericho, the first of which is Tel Es-sultan, located at the north west of the city, and dates back 10,000 years (8000 BC) and is known as the "oldest city in the world". Remains in archeological sites are concentrated mainly in the western sector of the city of Jericho, but there also a lot of other sites distributed in the Jordan Valley. These sites are the result of the different eras of history, from the Pre-Pottery Neolithic age, the Bronze age, the Hyksos period, the Canaanite period, the Persian, Hellenistic and Roman periods, and the Byzantine and Ottoman periods.

Around 100,000 years ago, the Red Sea extended north to the area of the Sea of Galilee. Then a combination of geological uplifts and a declining rainfall caused this inland gulf of water to retreat. 20,000 years ago a 220-km-long lake named Lisan ('tongue' in Arabic) extended from the Sea of Galilee to the Wadi 'Aruba. The increasingly arid climate caused the level of the lake to fall until, by 12,000 10,000 years ago, the Dead Sea and Sea of Galilee, as seen today were formed. Linking them is the 104-km-long Jordan River Valley with a width ranging from 5 to $20 \mathrm{~km}$. The valley has two levels: the valley floor, or Ghor in Arabic, and the river floodplain, or Zor in Arabic. It was this Zor zone with its thick belt of trees and that was referred to in the Bible as "the jungle of the Jordan" or "the pride of the Jordan" (Jeremiah 12: 5; Zachariah 11:3). The Jordan River flowed into the Dead Sea, and was fed by many wadis (small rivers in Arabic) from the west and east, created by perennial fresh water springs. These springs were part of the natural ground water system until they were exposed in deep chasms produced by the creation of the Rift Valley. These fresh water sources have enabled a rich environment of plant and animal life to flourish while attracting a burgeoning human population.

Due to its greater rainfall, there are more springs on the eastern side of the Jordan Valley than on the western side. This relative abundance of water allowed the earliest-known communities two of which are Pella and Drah, to be established over 10,000 years ago. When compared to the harsher and more arid conditions of Jordan's eastern plateau or the Negev and Sinai deserts, one can readily imagine that the Jordan Rift Valley was indeed the lush well-watered land referred to in the Bible as the "garden of God" (Genesis 13:10-11).

Early expeditions in the Jordan Valley were characterized by massive excavations on major archaeological sites (tells). This started in the late 19th century and continued through the first half of the 20th century, mainly conducted by British and German scholars. They managed to identify a few important sites that are partially related to biblical history of the region, as well as the Hellenistic-Roman and Byzantine periods. In the first half of the 20th century, archeologists made some important discoveries that go back to the prehistoric periods. Still, it is believed that many remains of various prehistoric periods are still resting untouched below the ground surface, and that new findings and additional sites may be uncovered in the years ahead.

Eco Peace is bringing attention to the cultural heritage and environmental values and challenges of the Jordan Valley to faith-based communities that reside in and visit the valley. As the river is emphasized as a symbol in Christianity, Judaism, and Islam with hundreds of thousands of pilgrims visiting each year, EcoPeace is working with faith-based communities to firmly tie the river's religious significance to the importance of its environmental preservation. To advance awareness and understanding of the problems and the potential rehabilitation of the lower part of the Jordan River, Eco Peace has developed faith-based tool kits to launch campaigns that are geared toward congregations from each of the three Abrahamic religions. The Jordan River Peace Park, the Auja Eco Center, and the Sharhabil Ben Hassneh Ecopark (SHE) play a crucial role in this work. Here, local students and faith-based groups visiting the valley are encouraged to discuss the river's current state and potential rehabilitation (Fig. 2.14).

The Jordan Valley and its surroundings can provide authentic, natural, and cultural experiences for tourism demands. Its unique natural and cultural history is not only a resource for tourism development, but it is also an important site to understand and appreciate for the preservation of its 


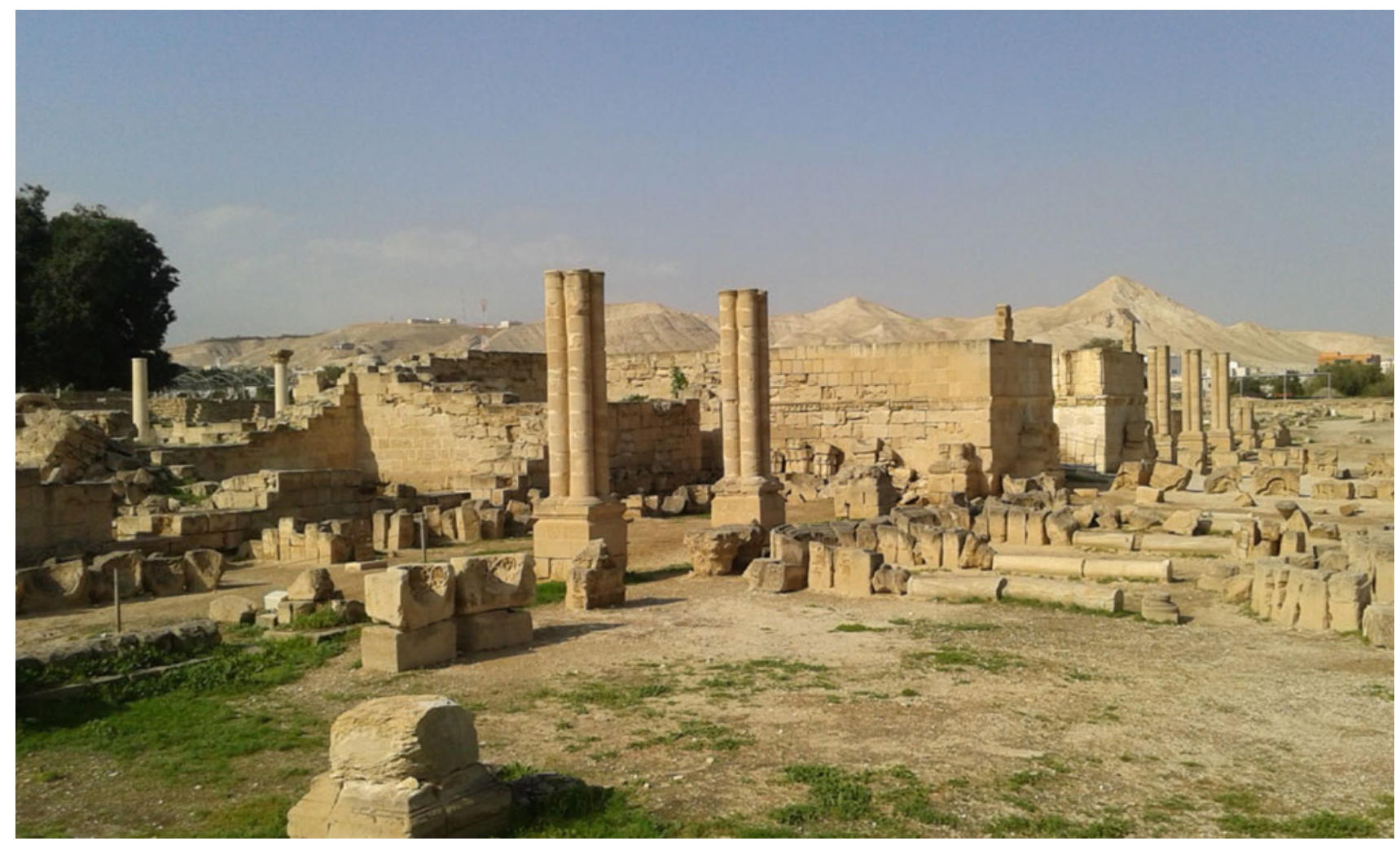

Fig. 2.14 Ancient Hisham Palace in Jericho

natural and cultural resources. Responsible tourism can play an important role to raise the level of awareness on a local, regional, and international scale about the value of Jordan Valley and its conservation and protection measures. This is why the development of toruism in the Jordan Valley should consider the valley's vulnerability to intensive exploitation of its resources. Competition between the countries within the Jordan Valley to maximize their exploitation of its resources will destroy the valley's value and will create more regional conflicts that will make the conservation of the Jordan Valley an international responsibility (Fig. 2.15).

Jericho

Jericho is considered to be the oldest continuously inhabited city in the world; it has been home to human beings for 10,000 years. During Roman rule (63 BC-423 $\mathrm{AD})$, Mark Anthony gave the city as a present to his beloved Cleopatra. After her suicide, it reverted to Augustus Caesar, who himself gave it to Herod. From this time, Jericho became a centre of Christianity and continued to be an important city throughout the Byzantine Period.

Al Maghtas-Baptism Site

The Baptism Site, "Bethany Beyond the Jordan (Al-Maghtas), protected area is located in the Southern Jordan Valley on the east side of the Jordan River around $9 \mathrm{~km}$ north of the Dead Sea and is part of the district of
South Shuneh in the Governorate of Al-Balqa. The site is located a few kilometers to the east of the oasis and ancient site of Jericho and ca. $50 \mathrm{~km}$ west of Amman, the capital of Jordan. The site covers an area of 533.7 ha where five archaeological sites dating back to the Roman and Byzantine periods were discovered. The precise limits of the archaeological remains are undetermined, although all identifiable cultural traces are included in the protected area. Several modern villages are located in the vicinity of the property. These include Al-Kafrein, Al-Ramah, Al-Jofah, Al-Rawdah, Sweimeh, New Shuneh, Al-Karamah, Al-Nahdah, Al-Jawasreh, Nimrin Al-Gharbi and Nimrin Al-Sharqi.

\section{Tabaqat FahaNPella}

Ancient Pella at Tabaqat Fahal is one of the most important archaeological sites in the Jordan Valley. Its central location in the land of biblical 'Gilead' on the most strategic east-west trade route to the Mediterranean coast was the key to its prosperity. The city is referred to almost a hundred times in various historical texts including the Old Testament which names this city 'Penuel' and records that it was here that Jacob wrestled with God who was in the form of an angel (Genesis 32: 22-30). The famous Amarna letters from ancient Egypt name Mut-Baalu as the ruler of Pella in the 14th century BC. During the Bronze and Iron Ages, Pella had the largest known Migdal-type temple in the entire 
Fig. 2.15 Walls of Ancient Jericho

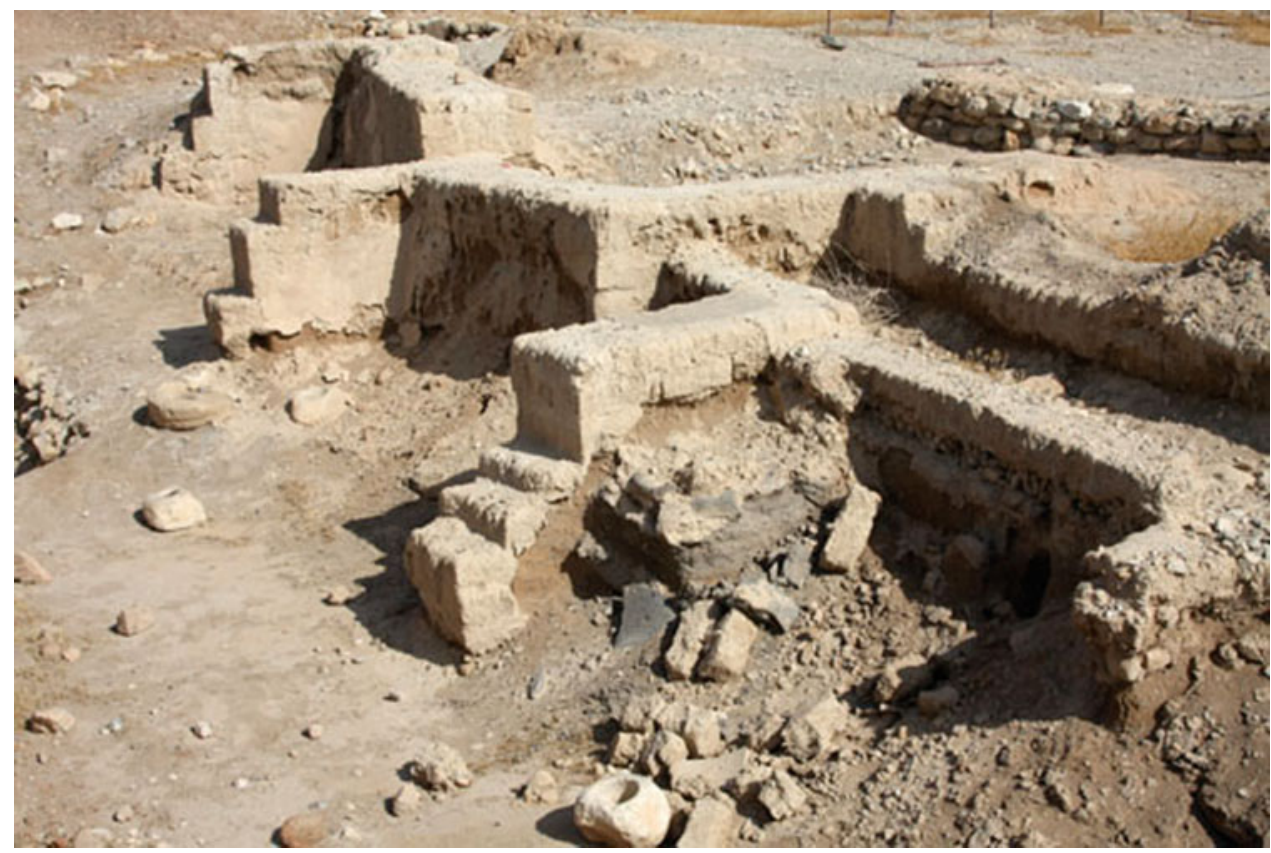

region. The base of this massive multi-storied structure measures $32 \times 24 \mathrm{~m}$ with two fortified towers dedicated to the Canaanite God Baal. In the fourth century BC, Pella was established as a Hellenistic city and was later included in the Roman Decapolis league. Some of the first Christian converts were known to have taken refuge from Roman persecution here in around $70 \mathrm{AD}$. The city thrived during the Byzantine period with three basilica churches.

It is intriguing to note that a thirteenth to fifteenth century mosque was built on the same site as the Bronze Age Migdol temple of Baal.

\section{Tell Deir Alla}

Strategically located at the mouth of the river Jabbok/Wadi Zarqa, Deir Alla is the Old Testament site of Succoth (Genesis 33: 17; Joshua 13: 27; 1 Kings 7: 46; 2 Chronicles 4: 17; Psalms 60: 6; and 108: 7) which was purported to have been fortified by Jeroboam and visited by Gideon as he pursued the eastward-retreating Midnights (1 Kings 12: 25; Judges 8: 5-17). Succoth means 'small structures' which may have derived from the ancient town's function as a central market place for the Gilead region during the Late Bronze and Iron Ages. To this day it remains a trading center for the Jordan Valley. Archaeological excavations have also revealed an important sanctuary here where many items bought in the town may have been donated as offerings (Fig. 2.16).
The Tomb of Abu 'Ubaydah (north of Deir Alla)

Abu 'Ubaydah 'Amr ibn Algeria was a relative and one of the 'Blessed Ten' companions of the Prophet Mohammed who were assured a place in heaven. During the Battle of Uhud he broke his front tooth whilst pulling a link of chain mail from the Prophet's cheek and because of this act the Prophet personally named him as an Ameen (trusted guardian) of the Nation of Islam. Abu 'Ubaydah led the Northern Army of Muslims after the Prophet's death, and also contributed to the writing of the Holy Qua'ran. He died during a plague in the central Jordan Valley where he is buried. An impressive modern mosque complex has been built over Abu 'Ubaydah's tomb which serves as the principle Islamic center in the Jordan Valley (Fig. 2.17).

The Hydroelectric power station at Bakoura/Naharyim

In 1927, Pinchas Rutenberg, a Russian immigrant and founder of the Palestine Electric Company (PEC), reached a unique agreement with HM King Abdullah I of Jordan to build the company's main hydroelectric power station. To this aim, canals and dams were built, creating a manmade island that harnessed the flow of the two rivers to produce electricity. By 1932 the hydroelectric power plant began supplying electricity on both sides of the river and continued to do so until it ceased operations as a result of the Israeli-Arab hostilities of 1948. In 1994, with the signing of the Peace Treaty by Jordan and Israel, the island was 
Fig. 2.16 Tell Deir Alla

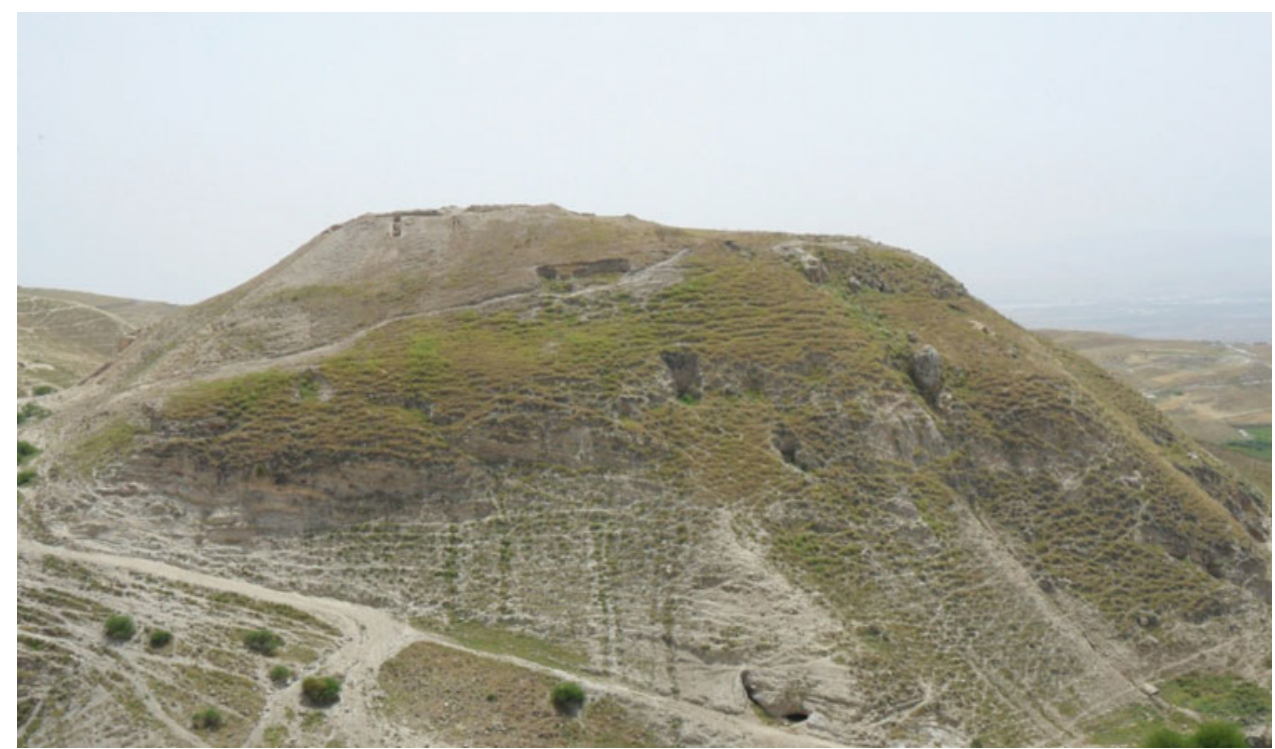

Fig. 2.17 The tomb of abu 'Ubaydah

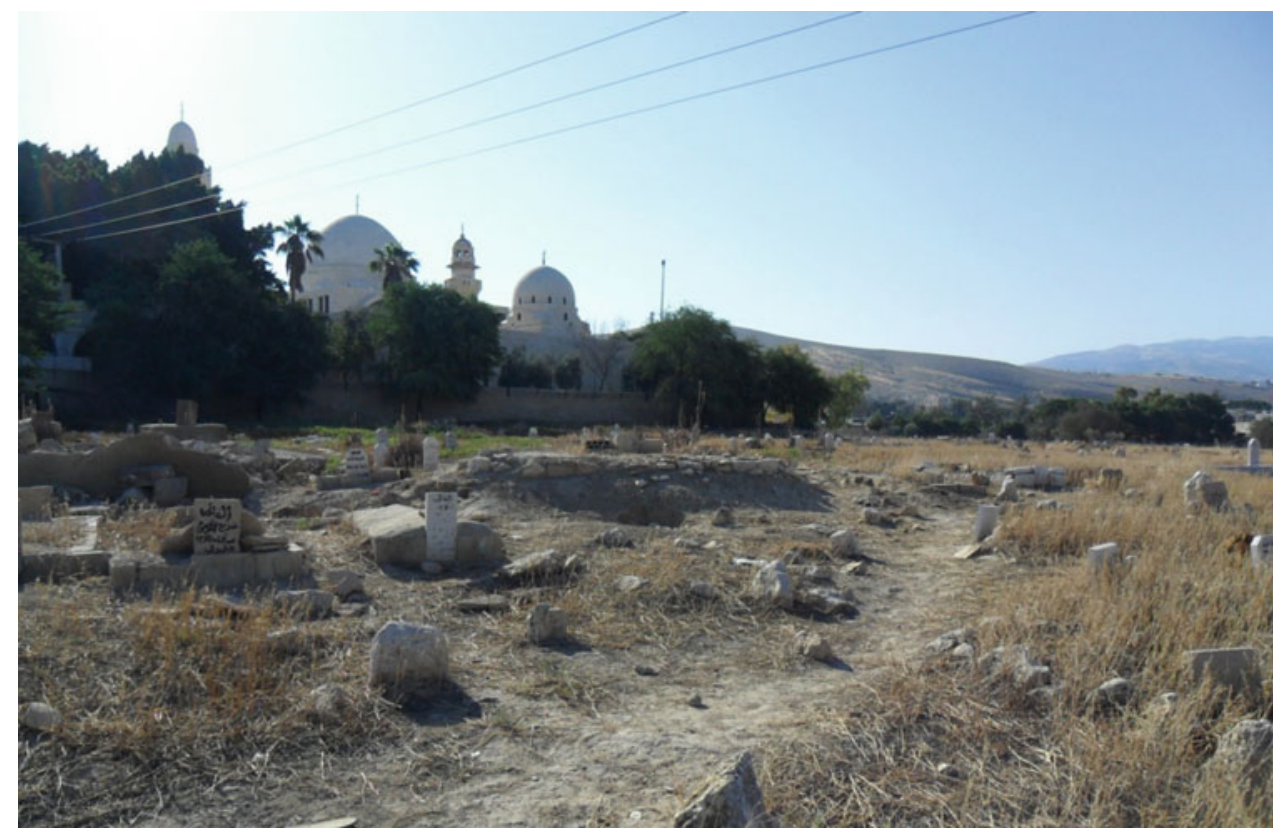

returned to Jordan but was leased with special usage and visitation status to Israeli and international tourists. Today a tour is offered from the Israeli entrance at Naharayim, where one can cross to the island, catch a glimpse of the river beneath, and see the remnants of the power station. Military personnel schedule and coordinate opening the fences on both sides, allowing tens of thousands of visitors per year to enter the island without the need for a visa. The municipalities on both sides, supported by WEDO/EcoPeace, propose to expand this area into a trans-boundary park, the Jordan River Peace Park, reaching $3 \mathrm{~km}$ down the meandering river to the Jeser Al Majama/Gesher site.

\section{Tel Rehov}

Tel Rehov is an important Bronze and Iron Age archaeological site approximately five kilometers south of Beit Shean and $3 \mathrm{~km}$ west of the Jordan River. The site represents one of the largest ancient city mounds in Israel, its surface area comprising $120,000 \mathrm{~m}^{2}$ in size, divided into an "Upper City" (40,000 $\left.\mathrm{m}^{2}\right)$ and a "Lower City" $\left(80,000 \mathrm{~m}^{2}\right)$. Archaeological excavations have been conducted at Rehov since 1997, under the directorship of Amihai Mazar. The excavations revealed successive occupational layers from the Late Bronze Age and Iron Age. In September 2007, 30 intact old beehives, made of straw and unbaked clay, dated to the 
Fig. 2.18 Belvoir fortress

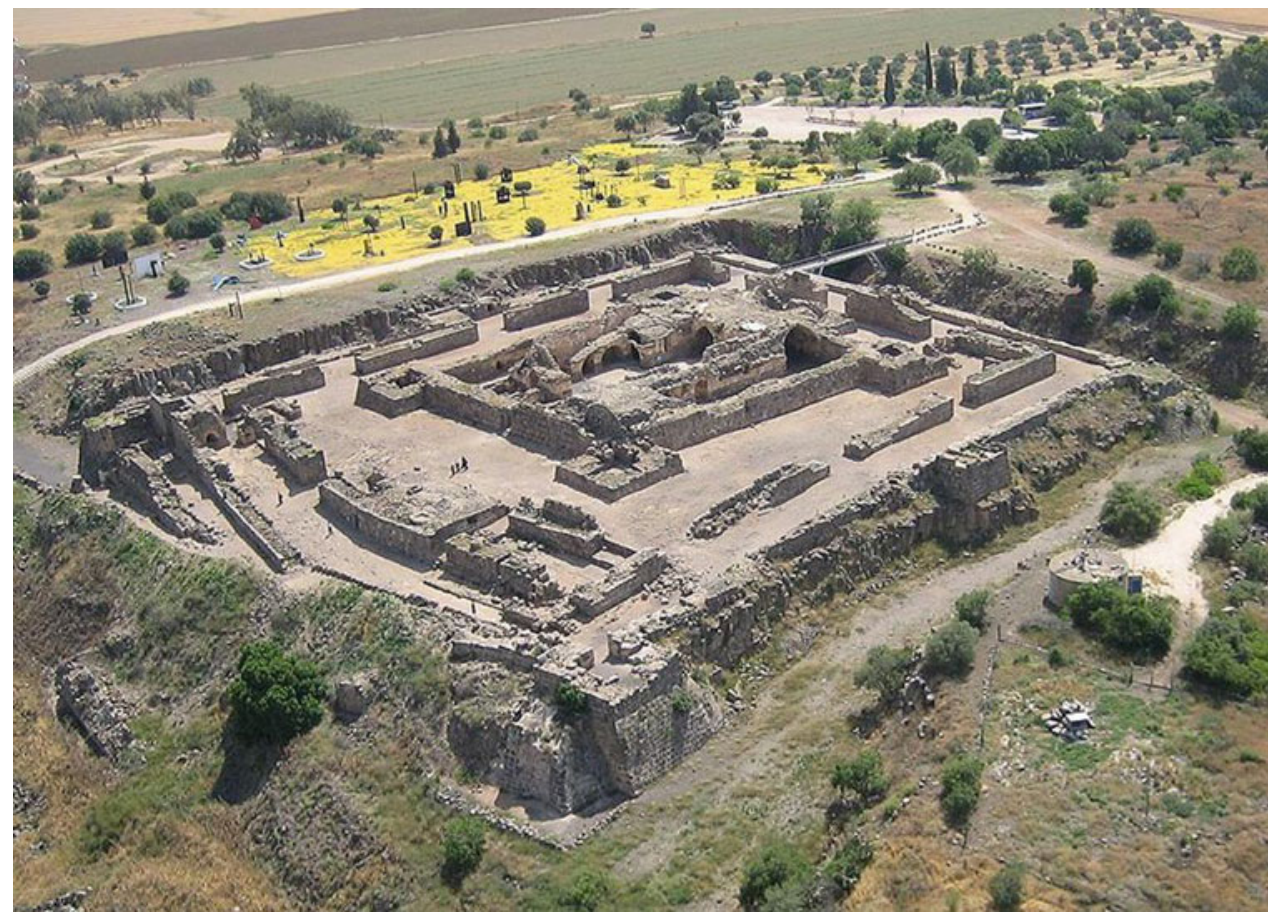

mid-10th to early 9th Century BCE were found. This is evidence of an advanced honey-producing beekeeping industry 3,000 years ago in the city which is thought to had a population of around 2,000 then. Also found alongside the hives was an altar decorated with fertility figurines (Fig. 2.18).

\section{Tel Ubeidiya}

Tel Ubeidiya, located some $3 \mathrm{~km}$ south of the Sea of Galilee, is another archaeological site of the Pleistocene, ca. 1.5 million years ago, and has preserved traces of the earliest migration of Homo erectus out of Africa. The site yielded hand axes of the Acheulean type. Tel Ubeidiya is located between the village Menahamia and Kibbutz Beit Zera, $1 \mathrm{~km}$ northwest of the kibbutz Beit Zera. Prehistoric remains as old as about 1.7 million years were found northwest of the Tel Artifacts discovered in the excavations, included human bones and remains of ancient animals. The site also features rock surfaces in which prehistoric humans lived during the Pleistocene period. As a result of geologic breakage and foldage activity, the rock surfaces are now inclined at an angle of $70^{\circ}$. It is thought that the area used to feature a pristine lake along which Homo erectus lived after his exodus from Africa.

\section{As-Sinnabra}

As-Sinnabra, or Sinn en-Nabra, is a historic site on the southern shore of the Sea of Galilee. The hill upon which al-Sinnabra was situated, Khirbet Karak of Beit Yerah, is one of the largest tels in the area, spanning an area of over 50 acres. In the Hellinistic era, Beit Yerah was a twin-city of
al-Sinnabra, located at the same tel. The city was inhabited in the Hellenistic, Roman-Byzantine, and early Islamic periods. Later, an Arabic "Qasr" was located here known as as-Sinnabra and served as a winter resort for the Umayyad from 650-704 AD. During the Crusader period, a bridge, called the "Crusader Bridge of Sennabris" was constructed here over the Jordan River, which at the time ran to the immediate north of the village.

\section{Belvoir Fortress}

Belvoir Fortress is a crusader fortress, located on a hill $20 \mathrm{~km}$ south of the Sea of Galilee. Its construction began in 1168 , and is currently located in Belvoir National Park. It is the best-preserved Crusader fortress in Israel. Standing $500 \mathrm{~m}$ above the Jordan Valley, the plateau commanded the route from Gilead into Israel and a nearby Jordan River crossing, and as such dominated the surrounding area. It has been known to have served as a major obstacle to the Muslim goal of invading the Crusader "Kingdom of Jerusalem." It withstood an attack by Muslim forces in 1180, but eventually was conquered during the campaign of 1182 in the Battle of Belvoir Castle by Saladin.

\section{Beit Alpha}

Beit Alpha is a sixth-century synagogue, located at the foot of the northern slopes of the Gilboa Mountains near Beit Shean. It is now part of Bet Alfa Synagogue National Park and managed by the Israel Nature and Parks Authority. Architectural remains from the Beth Alpha synagogue indicate that the synagogue once stood as two-story basilic building and contained a courtyard, vestibule, and prayer 
hall. The first floor of the prayer hall consisted of a central nave measuring $5.4 \mathrm{~m}$ wide, the apse, which served as the resting place for the Torah Ark, the bema, the raised platform upon which the Torah would have been read, and benches. The Torah Ark within the apse was aligned southwest, in the direction of Jerusalem.

\section{Hamadia}

Hamadia is a kibbutz just north of Beit Shean. It belongs to the Valley of Springs Regional Council, and is situated on a terrace of ancient Lake Beisan, $200 \mathrm{~m}$ below sea level. Tel Hamadia is a single layer archaeological site of about $100 \mathrm{~m}^{2}$, first reported and excavated at Hamadia by Tzori in 1958. It contains ovens, pits, and fireplaces with Yarmukian pottery. Large saw elements indicated possible earlier Neolithic occupation as well.

\section{Maoz Haim Synagogue}

The Maoz Haim Synagogue was originally constructed in the 3rd century as a simple Byzantine-era basilica, and later apsidical, building, in the Beit Shean region. Discovered in February 1974 by Mr. A. Ya'aqobi, it stands out as an unusual archeological find that contains a record of synagogue development from a time of otherwise sparse historiography. The synagogue was located amongst a large settlement in which it served as a center of worship for Jews there from its beginning up through its final destruction by fire sometime in the early 7th century. The initial layout began as a fourteen by twelve-and-a half meter square room with two rows of five columns benches lining the walls, although none remain standing.

\section{Beit Shean}

The pre-historic settlement at Beit Shean has often been strategically significant, as it sits at the junction of the Jordan River Valley and the Yezreel Valley, essentially controlling access from the interior to the coast. It is suggested that settlement began in the sixth to fifth millennia BCE. Occupation continued intermittently up to the late Early Bronze Age I from 3200-3000 BCE. After the Egyptian conquest of Beit Shean by pharaoh Thutmose III in the 15th Century BCE, the small town became the center of the Egyptian administration of the region. The Egyptian newcomers changed the organization of the town and left a great deal of material culture behind. An Iron Age I Canaanite city was constructed on the site of the Egyptian center shortly after its destruction. Around 1100 BC, Canaanite Beit Shean was conquered by the Philistines. The Hellenistic period saw the reoccupation of the site of Beit Shean under the new name Scythopolis. In 63 BCE Pompey made Judea a part of the Roman Empire. Beit Shean was re-established and rebuilt by the name of Gabinius. The town center shifted from the summit of the Mound (the "Tel") to its slopes. Scythopolis prospered and became the leading city of the Decapolis, a loose confederation of ten cities which were centers of Greco-Roman culture.

\subsubsection{Infrastructure}

\section{Main bridges over the Jordan River}

The Jordan Valley connects Israel with Jordan though the Sheikh Hussein Bridge in the north, and Palestine with Jordan through the King Hussein (Allenby) Bridge. The King Hussein Bridge is located just outside Jericho city and is the only connection between the Palestinian West Bank and Jordan. The West Bank side of the King Hussein/Allenby Bridge is considered a border entry point by the Israeli Authorities. The Jordanian authorities recognize the bridge as an international border entry point, but in contrast to other border crossings with Israel, do not grant entry visas to foreign passport holders at this crossing. Palestinians traveling abroad must use this bridge to exit the West Bank into Jordan and then use the Queen Alia International Airport in Amman to fly abroad, because they are not permitted to use Ben Gurion Airport near Tel Aviv. Travel permits from both Israeli and Jordanian authorities are required, with varied stringency depending on the political situation. Israeli citizens are not permitted to use the terminal. Tourists who wish to travel to Jordan must be in possession of a visa from Jordan in advance, with the exception of Palestinians who are allowed to travel to Jordan without a permit. Foreigners who leave Jordan via the King Hussein Bridge may return by showing the exit visa. Tourists and inhabitants of East Jerusalem may travel directly to an Israeli terminal, although Palestinians from the West Bank have to start the departure procedure at the special Palestinian border terminal in Jericho city.

\section{Road Network in Jordan}

The Dead Sea Highway (Route 65) is the major regional highway in Jordan that crosses the Jordan Valley from north to south along the western Jordanian border and Dead Sea shoreline. All other roads leading to and leaving from the Jordan Valley connect to this road. The road passes through some heavily populated urban areas where it is widened to four lanes and lined with shops and buildings on both sides of the road.

This road is heavily used for local traffic as well as regional transportation. The traffic along Route 65 is dense, consisting of slow moving trucks carrying agricultural produce, farm vehicles, and local traffic. The road is heavily intersected by minor roads used by farmers. Most intersections with major roads are signalized. The Dead Sea 
Highway along the Jordan Valley is poorly serviced for major sections, and there is a need for maintenance and improvements, particularly pavement, marking, and signage. There are plans to upgrade the road into four divided lanes or to construct a new highway parallel to the existing one.

\section{Traffic Safety}

Although no detailed information is available on traffic accidents in the Jordan Valley, the number of traffic deaths in Jordan as a whole is relatively high with 12 to 14 deaths per 100,000 inhabitants (ref. Jordan Traffic Institute, 2011). In 2010 Jordan had a total of about 1 million registered vehicles; including 770,000 4-wheeled light vehicles and 100,000 buses. Extrapolating the traffic accident percentages to the current population in the Jordan Valley would imply 25-30 traffic deaths on average in the Jordan Valley. Statistics show that $63 \%$ of these casualties are among drivers and passengers of 4-wheeled cars and light vehicles, $33 \%$ among pedestrians and $4 \%$ among buses and heavy trucks. Improving road safety conditions along Route 65, including street lighting and separate protected pedestrian lanes and cross-overs will likely reduce the annual number of deathly traffic accidents considerably.

The government is considering to either upgrade the Route 65 , or to construct a new parallel highway though the LJR Valley. The argument for constructing a new highway is currently stronger than that of upgrading the existing road, as upgrading entails demolition of existing village buildings and farms. In addition, increased traffic will increase noise, pollution, and accidents in urban areas. The large number of intersections also makes the existing highway unsuitable for international (through) traffic.

The Amman-Naur-Dead Sea (Route 40) is the main entrance in Jordan to the Jordan Valley. It is a well engineered four-lane divided expressway, but there are steep inclines that slow down heavy trucks. The last segment of this road from Al Rama intersection to Al Quds intersection with Route 65 has been upgraded to a four-lane divided highway.

The Al Ardah-Al Salt Road (Route 24) connects with Route 65 approximately $32 \mathrm{~km}$ north of South Shuneh. This road is a rural two-lane two-way road of approximately $8 \mathrm{~m}$-wide carriageway that climbs along the wadi up to $\mathrm{Al}$ Salt for approximately $23 \mathrm{~km}$. The intersection with Route 65 (Muthallath Al Arada) is a signalized " $T$ " Intersection. The road at the intersection is widened to four lanes, with shops and buildings on both sides. The road has some very sharp reverse and broken back curves and steep grades. The surface of the road needs rehabilitation to repair pavement cracks and potholes. In addition, some protection from falling rocks and drainage works are needed.

Continuing north (approximately $15 \mathrm{~km}$ ) along Route 65 from Muthallath Al Arada intersection is the intersection of the Kufranja-Ajloun Road. This is a two-lane, two-way undivided rural road that runs for about $24 \mathrm{~km}$ to Kufranja and Ajloun. This road has approximately $6 \mathrm{~m}$ of paved width. The road climbs up the hills and mountains towards Ajloun.

The Qalat ar Rabad-Ajloun Road climbs along Wadi Al Yabis passing Qalat (Castle) ar Rabad on to Ajloun (approximately $40 \mathrm{~km}$ ). The road intersects Route 65 approximately $12 \mathrm{~km}$ north of Kufranja-Ajloun Road. This two-lane road features approximately a $7 \mathrm{~m}$-wide paved carriage way. Further north (approximately $16 \mathrm{~km}$ ) along Route 65 is the intersection with Abu Saeed-Irbid Road. This two-lane, two-way road climbs about $34 \mathrm{~km}$ up to Irbid city. The Ash Shuneh (North)-Irbid (Route 16) two-lane, two-way road has been upgraded to a four-lane divided rural highway with shoulders.

\section{Infrastructure network in Israel and Palestine}

On the western side of the Jordan River, the main road from north to south is route 90 . This road runs all the way from Metula in the north of Israel to Eilat in the south. Where the road enters and leaves the West Bank, two checkpoints have been erected: the northern one near the Bezeq Stream and Sdei Trumot, and the southern one along the Dead Sea just north of Ein Gedi. Palestinians living in the West Bank are not allowed to pass these checkpoints unless permits from the Israeli Authorities are obtained.

Other major roads that cross the region are Routes 505 and 508, known in Hebrew as the Alon Road. Just north of the Dead Sea at the Beit Ha Arava junction, Route 90 crosses Route 1, leading to west through the West Bank towards Bethlehem, Jerusalem, and Tel Aviv. Highway 90 bypasses Jericho from the east. The entrance road to Jericho was recently opened, allowing both a north and south entrance. Driving north from Ein Gedi, Israel, one passes an Israeli military checkpoint while crossing into the West Bank.

A secondary level network connects Jericho to the other Governorates, mainly branching from Road 90 to Nablus (Road 505) and Ramallah, and to Jerusalem (Road 1). Four access points link Jericho city to its surroundings: two in the northern part towards Al Auja, Nablus, and the northern part of the Jordan Valley, one towards east Jordan, and one south west towards Ramallah and Jerusalem. The region of Jericho is connected to the other urban centers by public transport, mainly mini van buses. Jericho city is the main hub toward the surrounding villages and houses the main national bus stations (Nablus for the northern regions, Ramallah for all Palestine, Bethlehem for the southern regions). In addition to that, the main cities of Palestine are linked to the border station (Esteraha) by a bus service.

On the western side road 90 along the valley is a major tourism artery connecting Jerusalem and then Jericho with the SoG. Many foreign tourists take this journey along road 
90 which presents real opportunity for further development in the valley. The main tourism route in Jordan is AmmanJerash and south to Petra. Jordan would therefore also benefit if border crossings were easier for tourists capturing some of the road 90 market on the west side.

\section{Public Transport}

The main public transport in the Jordan Valley in Jordan is by minibus. In general, these buses travel frequently, but without fixed schedules contingent on the number of passengers. Minibuses generally stop anywhere at request. For many destinations in the Jordan Valley, the minibus is the only other public transport option. Some large air-conditioned bus companies operate in Jordan as well, although mainly along the main routes such as from Amman to Aqaba or Amman to Petra. There is no information that any bus routes pass through the Jordan Valley. The system of shared taxis is also applied in Jordan. Like the minibuses, they pick up passengers and generally depart to specific destinations when full.

In Israel, public buses are the main form of public transport in the Jordan Valley. Within Israel a total of 16 different companies operate buses for public transport, with Egged being the largest bus company operating routes throughout the country. Buses travel frequently from Beit Shean to Afula, Haifa, and Jerusalem. Smaller carriers, operated by companies liked Dan Bus Company offer alternative public transport services. In addition to regular taxicab services, shared taxi services, often yellow minivans, are available as well and are, run by private companies. The shared taxis allow passengers generally to get in and leave anywhere along the path of travel. During Shabbat normal buses services cease their operations.

A new train line from Haifa to Bet Shean is expected to be completed and running in 2016. The train will have two stations in Bet Shean. There were plans in the mid 1990s to link the Beit Shean Railway across the Jordan River with a Jordanian rail network but it never materialized.

For most cities in Palestine, taxis are widely available, but the Palestinian taxies have blue and green license plates and are not permitted to enter Jerusalem. Jericho is well connected to other Palestinian cities by service taxis/ minivans. These are usually minivans which operate on a fixed route for a fixed price, similar to a bus.

\section{Energy}

The Jordanian national interconnected grid transmits electricity from the power stations to the distribution substations and transformer substations in the Jordan Valley via $400-\mathrm{kV}$ and $132-\mathrm{kV}$ power lines. The grid has a clearly identifiable north-south axis. The national $400-\mathrm{kV}$ power line runs outside the Jordan Valley from Aqaba via Amman and up to the Syrian border. In the north, the power grid is connected to the Syrian grid by means of a $230-\mathrm{kV}$ and a $400-\mathrm{kV}$ power line. In the south, there is a $400-\mathrm{kV}$ connection to the Egyptian grid. The interconnected grid feeds the local distribution systems via which almost the entire population of Jordan, including in the Jordan Valley receives its electricity.

The Israel Electric Corporation (IEC) is the sole integrated electric utility in Israel and generates and transmits substantially all of the electricity used in the country, including in the Jordan Valley. Like most countries in Europe, the Middle East, and Asia, the electricity in Israel is rated at $220 \mathrm{~V}(220-240 \mathrm{~V})$ and $50 \mathrm{~Hz}$.

The framework for the electricity power supply varies in Palestine between the Jordan Valley and the rest of Palestine. The Jordan Valley has two different sources: the first is Israeli, which is additionally connected to palestine. This network serves Israel well, but provides insufficient capacity to serve all Palestinians adequately. The solution is expected Palestinian interconnection with Jordan: PNA and Jordan have agreed on connecting the Palestinian power grid to the Jordanian grid with a $33 \mathrm{kV}$ transmission line through King Abdullah Bridge, with a capacity of $20 \mathrm{MW}$. A transformer substation will be built in the south of the Jericho City and connected to the existing network. Other Palestinian communities get the electricity from JDECO (Jerusalem District Electricity Company), or from the Israeli company Qutria.

WEDO/EcoPeace is currently researching the possibility to create a water and energy nexus across the region. This entails investments in the eastern deserts of Jordan proposed to be producers of large scale solar based renewable energy that would be traded by Jordan with Israel and Palestine. Israel and Palestine would in turn use some of that electricity to desalinate the Mediterranean Sea waters to be traded with Jordan. Though the nexus concept is outside of the Jordan Valley, the implications for the valley are significant. It would make large quantities of renewable energy available and reduce pressure on the current demand for the natural waters of the valley. See also the report Water_Energy_Nexus_Web3.pdf at www.foeme.org

The Jordan Valley is a strategic location that functions as a west-east corridor from the Mediterranean Sea, Israel and Palestine to Jordan and other neighboring countries. It has also been a North-South transport corridor. The Jordan Valley opens up many opportunities for regional continuity. This includes establishing land transport, energy and communications connections between the parties in the region, as well as logistical facilities to serve both regional and international economic activities which will enable more diverse and efficient routing options for the flow of goods and people, both regionally and internationally. A major 
component of economic development of the Palestinian Jordan Valley is upgrading of west-east transportation routes.

\subsection{It's People}

\subsubsection{Population}

The Jordan Valley houses a population of about 605,000 people. The information with regard to the population numbers in the study area have been obtained through the Jordanian Department of Statistics (DOS), the Central Bureau of Statistics in Israel, and the Palestinian Central Bureau of Statistics. For the Jordan and Israeli parts of the study area there has been an organic growth of the population, except for the recent influx of refugees from Iraq and Syria in Jordan. This contrasts with the Palestinians, for which the economic opportunities in the region have been much more limited since the late 1960s. Palestinian youth has often been commuting or migrated to other regions in and outside the West Bank looking for opportunities in the labor markets.

The population growth rates for the Jordanian and Israeli sections of the study area are estimated at respectively $2.2 \%$ and $1.87 \%$. For Jordan the growth rate during the period 1994-2004 was calculated at $2.6 \%$ and decreased to $2.2 \%$ during the period 2004-2010. A slightly further decline of the birth rate in Jordan is expected, however the communities in the Jordan Valley follows the national trends with some years delay and therefore the birth rate for the period 2011-2020 is estimated at $2.2 \%$.

Separate from the registered Jordanian population, the Jordan Valley houses large number of informal foreign workers originating mainly from Egypt and Iraq, and lately including some refugees from Syria. It is estimated that a total of about 250,000 nonregistered people live in the Jordan Valley today, many of them employed as temporary workers in the agricultural sector.

In addition, the United Nations had registered 619,000 official refugees from Syria in Jordan in August 2014, with over 80,000 registered in the refugee camp Za'atri, located close to the Syrian border just outside the study area. However, the impact of these refugees on the population in the Jordan Valley is limited, due to strict travel restrictions for Syrian refugees, enforced through checkpoints on the roads towards the Jordan Valley.

For Israel the current population growth rate is about $1.87 \%$ and no further decline is expected in the study area as a large percentage of the population living in rural communities commonly have higher birth rates than in urban communities. Various studies show that Palestinians in the occupied West Bank Area C, including the Jordan Valley, have declined drastically over the last years, mainly as result of migration of Palestinians to areas A, where the economic perspectives and public services, such as water, sanitation and electricity are much better.

An estimated total of 6245 people live in about 26 Israeli Settlements within the West Bank part of the study area, divided over Cluster North, including the settlements of Mehola, Shadmot, Maskoit and Rotem; Cluster Central, including a total of 18 small settlements, and Cluster South, including the settlements of Vered Yeriho, Beit Harava, Almog, and Kalia.

Table 2.5 provides an overview of the population figures.

\subsubsection{Socio-economic Situation}

The native inhabitants of the Jordan Valley in the early 19th century are known as Al Ghawarna or Ghorani (meaning people of $\mathrm{Al}$ Ghor), and were involved in mixed farms that

Table 2.5 Estimated population in the study area (2010)

\begin{tabular}{l|l}
\hline Country & 2010 \\
\hline Jordan & \\
\hline North Shouneh & 108,943 \\
\hline Deir Alla & 67,925 \\
\hline South Shouneh & 70,294 \\
\hline Foreign population & 247,000 \\
\hline Total Jordan & 494,162 \\
\hline Israel & \\
\hline Emek Hayarden & 11,000 \\
\hline Emek Hamaayanot & 11,000 \\
\hline Beit Shean & 17,000 \\
\hline Hagilbo'a & 10,000 \\
\hline Total Israel & 49,000 \\
\hline Palestine & \\
\hline Palestinians & \\
\hline Bardala Cluster MD & 5,259 \\
\hline Al-Nassariya Cluster MD & 4,564 \\
\hline Al-Jiftlik Cluster MD & 6,499 \\
\hline Fasayil Cluster MD & 1,157 \\
\hline Al-Auja Cluster MD & 4,423 \\
\hline Jericho MD & 34,112 \\
\hline Subtotal Palestinian & 56,014 \\
\hline Settlements & \\
\hline Cluster North MD & 6,250 \\
\hline Cluster Central MD & 8,259 \\
\hline Cluster South MD & \\
\hline Subtotal Israeli Settlers & \\
\hline Total Palestine & \\
\hline Total population Jordan Valley & \\
\hline &
\end{tabular}


covered crop and livestock production systems. Semi-nomadic Bedouins also live in the Jordan Valley and use the lands as grazing ground for their sheep and goats during the winter months because of its warm climate and available fodder for their animals. However they move their flocks up into the hills during the summer to avoid the intense heat.

Today, agriculture still dominates the socio-economic landscape of the study area, although there is significant inequality between the riparian states. The Israeli part of the valley is economically the most advanced zone, with a living standard comparable to some European countries. The World Bank classified Jordan as an "upper middle income country" with significant economic inequalities: In the Jordan Valley there is a small group of wealthy agricultural entrepreneurs, but also to a large group of laborers who live close to the poverty line of JD 32.6 per person per month. The Palestinian part of the valley, excluding the Israeli settlements, have a standard of living comparable to that in Jordan, be it that the remaining population living under occupation is small and are often subject to stringent movement restriction by the Israeli military authorities (Table 2.6).

The importance of agriculture is expected to decrease in the valley for all three riparian states. In Israel the proportion of the population engaged in the agricultural sector started to decline already in the 1970s when the industrial and service sectors achieved higher growth levels compared to the agricultural sector. A higher priority to agricultural development was given to regions with less tension between different water users (e.g. Negev Region). For Jordan and Palestine this shift from agriculture to service sector started during the 1990s and continues until today. It is expected that once a final peace settlement is in place, the Palestinians will see a further boost of their socio-economic level.

Table 2.7 provides an overview of some socio-economic parameters in the study area. These figures have been

Table 2.6 Socio-economic parameters

\begin{tabular}{|c|c|c|c|c|c|c|}
\hline \multirow{2}{*}{$\begin{array}{l}\text { Socio-economic statistics (2011) } \\
\text { Parameter }\end{array}$} & \multicolumn{2}{|l|}{ Jordan } & \multicolumn{2}{|l|}{ Israel } & \multicolumn{2}{|l|}{ Palestine } \\
\hline & Amount & Unit & Amount & Unit & Amount & Unit \\
\hline Average household size & 6 & pers & 3.3 & pers & 6 & pers \\
\hline Average monthly household expenditures & 701 & JD & 14460 & NIS & 1058.4 & JD \\
\hline Average monthly per capita expenditures & 117 & JD & 4382 & NIS & 188.1 & JD \\
\hline Average monthly income per household & 704 & JD & 14629 & NIS & 1100 & JD \\
\hline Illiteracy rate for persons aged $>15$ years & & & & & $4.1 \%$ & \\
\hline Males & 5 & $\%$ & 1.5 & $\%$ & & \\
\hline Females & 12.6 & $\%$ & 4.1 & $\%$ & & \\
\hline Gender ratio (= males/females in $\%)$ & 106.4 & $\%$ & 102.7 & $\%$ & 103.2 & $\%$ \\
\hline \multicolumn{7}{|l|}{ Labor force participation $>15$ years } \\
\hline Males & 63.4 & $\%$ & 68.6 & $\%$ & 69.1 & $\%$ \\
\hline Females & 17.8 & $\%$ & 61.3 & $\%$ & 17.4 & $\%$ \\
\hline Poverty rates & 12.5 & $\%$ & 22.5 & $\%$ & 23.7 & $\%$ \\
\hline \multicolumn{7}{|l|}{ Unemployment $>15$ years } \\
\hline Males & 11 & $\%$ & 5.6 & $\%$ & 17.3 & $\%$ \\
\hline Females & 21.2 & $\%$ & 20.2 & $\%$ & 25.3 & $\%$ \\
\hline \multicolumn{7}{|l|}{ Employment per sector $(\%)$} \\
\hline Agriculture, fishing, forestry & 20 & $\%$ & 1.6 & $\%$ & 33.3 & $\%$ \\
\hline Mining, quarrying and manufacturing & 9.5 & $\%$ & 11.5 & $\%$ & 7.6 & $\%$ \\
\hline Construction & 15 & $\%$ & 5 & $\%$ & 6.2 & $\%$ \\
\hline Commerce, restaurants, hotels & 20 & $\%$ & 19.5 & $\%$ & 13.3 & $\%$ \\
\hline Transportation & 6.5 & $\%$ & 3.8 & $\%$ & 5.1 & $\%$ \\
\hline Services, others & 29 & $\%$ & 58.6 & $\%$ & 34.5 & $\%$ \\
\hline \multicolumn{7}{|l|}{ Basic education (\%) } \\
\hline Males & 51.3 & $\%$ & 100 & $\%$ & & \\
\hline Females & 48.7 & $\%$ & 97.7 & $\%$ & & \\
\hline Population growth & 2.2 & $\%$ & 1.87 & $\%$ & \multicolumn{2}{|c|}{ Negative/migration } \\
\hline
\end{tabular}


Table 2.7 Main features of the three agricultural zones of the Jordan River Valley

\begin{tabular}{l|l|l|l}
\hline Characteristics & Zone 1 & Zone 2 & Zone 3 \\
\hline Elevation below sea level $(\mathrm{m})$ & $205-235$ & $235-315$ & $315-395$ \\
\hline Name & Northern JV District & Middle JV District & Southern JV District \\
\hline Administrative centre East Bank & North Shouneh & Deir Alaa & South Shouneh \\
\hline Administrative centre West Bank & Beit Shean & Tubas & Jericho \\
\hline Total degree of aridity & Semi arid & Semi arid-Arid & Arid-severely arid \\
\hline Percent area of soil class-A East Bank ${ }^{\mathrm{a}}$ & 43 & 29 & 18 \\
\hline Percent area of soil class-B East Bank & 41 & 27 & 17 \\
\hline Percent area of soil class-C East Bank & 13 & 12 & 7 \\
\hline Percent area of soil class-D East Bank & 3 & 32 & 58 \\
\hline Soure Jor & &
\end{tabular}

Source Jordan Valley Authority

${ }^{a}$ Class-A soil is deep and level and has good permeability, low salinity, and no clay (Marl). This type of soil is suitable for all types of crop. Class-B soil is similar to Class A but is shallower, less permeable, and slightly more saline. Class-C and -D soils are shallow and have high salinity and low permeability, as a result of the impediment offered by its clay layers

obtained from literature, from the Jordanian Department of Statistics (DOS), the Central Bureau of Statistics in Israel, and the Palestinian Central Bureau of Statistics, supported by data from indexmundi.com. This data reflect the status in the wider region around the Jordan Valley: this study did not include specific field data surveys in the Jordan Valley itself, and below data should therefore be considered indicatively.

Within the study area, the size of households in Jordan and Palestine are similar, about 6 persons per household, which is comparable to the wider Middle East region, while Israel has about 3.3 persons per household, which more resembles the situation in Europe (Fig. 2.19).

The differences in expenditures show slightly different patterns. Household and per capita expenditures in Jordan are resp. $701 \mathrm{JD}$ and $117 \mathrm{JD}$ (€ 728 and $€ 121$ ). In Palestine these are about $50 \%$ higher: 1058 JD and 188 JD $(€ 1098$ and $€ 195)$. In Israel, the household and per capita expenditures are about 5 times higher: 14460 NIS and 4382 NIS (€ 3.051 and $€$ 924). However, the Consumer Price Index for Jordan is about 65,55 against 92,24 for Israel and Palestine, meaning that Jordanians can buy about $40 \%$ more consumptions goods for their money than the Israeli's and Palestinians.

Unemployment rates (percentages of the labor force without a job) are relatively high for the region, with an exception of the male unemployment rate in Israel, which was $5.6 \%$ in 2011.

The male population Palestine has the highest unemployment rate with $17.3 \%$, followed by Jordan with $11 \%$. In respect to female populations, unemployment is again highest in Palestine (25.3\%), followed by Jordan $(21.2 \%)$ and Israel $(20.2 \%)$.

Fig. 2.19 Jericho city center

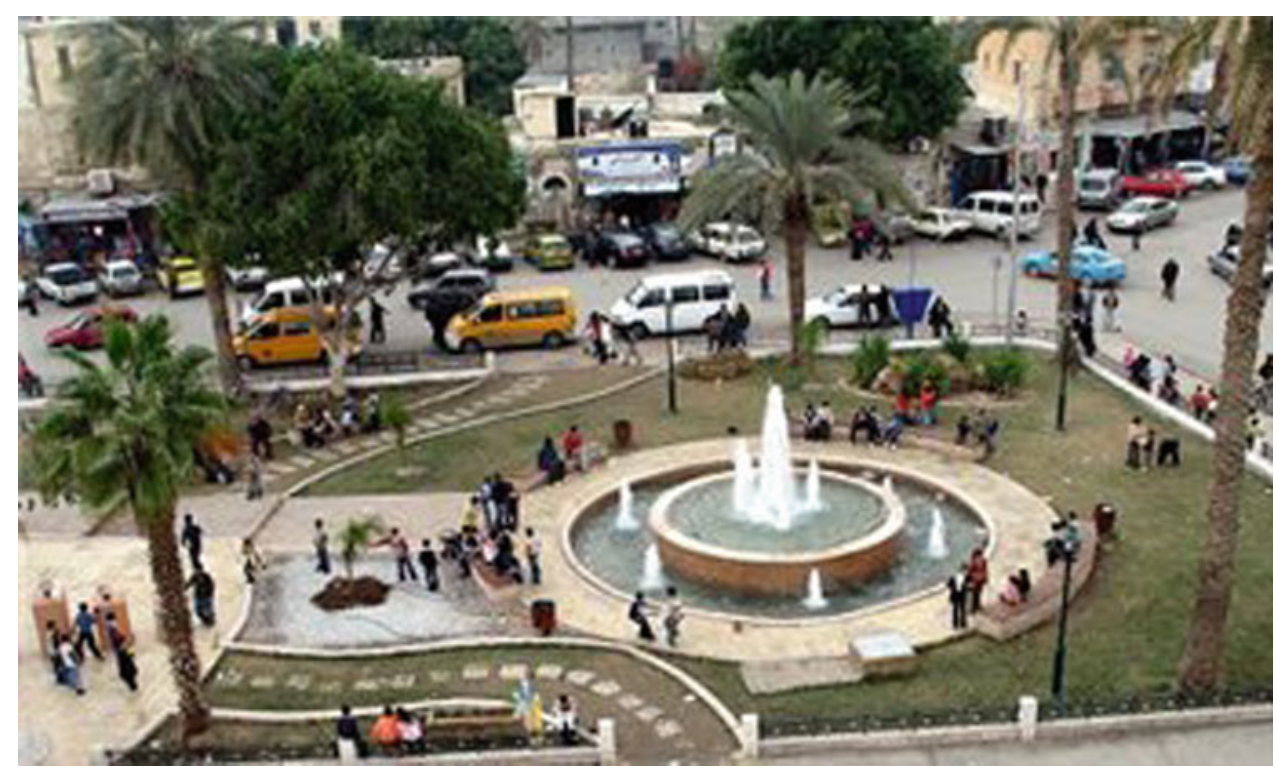


In all three countries there are considerable income disparities between the upper and lower strata of the societies. In the three riparian states a substantial proportion of the households are living below the poverty line: Jordan $12.5 \%$, Palestine $23.7 \%$ and Israel $22.5 \%$. It should be noted that the three countries apply different poverty definitions, and that in absolute income terms the poverty in Palestine is much more severe than in Israel. Nevertheless, the Gini Coefficient of Jordan and Israel confirms that large income disparities exist between the top $20 \%$ and the bottom $20 \%$ of the income earners, and the expectation is that a similar pattern can be observed in Palestine.

Employment rates per economic sector show that Palestine has a relative high portion of people working in the agricultural sector (33.3\%), while in Jordan this is estimated to be around $20 \%$, and only $1.6 \%$ of the Israeli working force is employed in the agricultural sector. Although detailed information on agricultural employment rates in the Jordan Valley are not available, it may be expected that agriculture is more important here than at national levels.

A different pattern can be seen in the construction sector, with $15 \%$ for Jordan and $6.2 \%$ for Palestine, against $5 \%$ in Israel. Sectors such as mining, manufacturing, commerce, restaurants, and hotels and transportation employ percentages which are more or less similar for the three countries. Finally the Service sector, including research and government, is best developed in Israel, employing $58.6 \%$ of the work force, against $39.8 \%$ in Jordan and $34.5 \%$ in Palestine. These differences may explain the income differences in the three countries, since the agriculture and construction sectors generate generally lower wages than the service sector.

The agricultural activities of the settlements in the Palestinian study area generate about 500 Million NIS of revenues. The total agricultural area in the West Bank part of the study area that is under control of Israel is approximately 60,000 dunum, including 4.470 dunum in Cluster North; 46.360 dunum in Cluster Central and 10.128 dunum in cluster south. Main crops are dates, vegetables, fruit trees and field crops. About one third of the Israeli settlement population is involved in agricultural activities, and another one third is engaged in agro-business related activities. The final one third of the working population is involved in industrial activities and services. In addition, an estimated 6,000 Palestinian workers are employed on a temporary basis in agricultural settlements.

The industrial activities of the settlements in the Palestinian study area include exports of dried fruits, dates, herbs and nuts; infrastructure contracting; packaging of grapes, figs, peppers, tomatoes and herbs, nylon bags production; metal works, rubber, plastics and sealing production; arts and crafts, marketing and investment in pesticides, fertilizers and packaging materials for farmers, and manufacturing cosmetic products from Dead Sea minerals.

The gender ratio in the Jordan Valley (number of males compared to number of females) is highest in Jordan $(106.4 \%)$, and similar in Israel and Palestine (102.7\% and $103.2 \%)$. Illiteracy rates in all three countries are relatively low: below $5 \%$, be it that females in Jordan are an exception with an average illiteracy ratio of $12.6 \%$. Labor force participation for the male population is also similar in all three countries: $63.4 \%$ in Jordan, $68.6 \%$ in Israel and $69.1 \%$ in Palestine. Differences are larger for the female population: $17.8 \%$ and $17.4 \%$ of women participate in the labor market in Jordan and Palestine, while $61.3 \%$ of the adult female work force participates in the labor market in Israel.

The gender issue in Jordan is influenced both by national socio-economic conditions as well as by tribal traditions. In some rural areas local Shari 'a courts have some jurisdiction over matters related to marriage, divorce and inheritance. The Jordanian National Commission for Women (JNCW) has established a network called Sham'a ("candle"), which aims to combat violence against women by coordinating the efforts of both governmental and non-governmental organizations. In 2009, the JNCW established a Women's Complaints Office to receive complaints of discrimination and violence against women in private and public life and to raise awareness of these issues and provide legal aid, among other services. This work is carried out in collaboration with governmental and non-governmental organizations. There are also several NGOs that provide services to women, and a national register on violence against women has been established. In 2007, the Ministry of Social Development created the "Family Reconciliation Centre" for victims of domestic violence.

In 2012, Israel ranked eleventh out of 59 developed nations for participation of women in the workplace. In the same survey, Israel was ranked 24th for the proportion of women serving in executive positions. Israeli law prohibits discrimination based on gender in employment and wages; nonetheless, there are still complaints of significant wage disparities between men and women in Israel, as well as significant social disparities particularly in orthodox communities. On the other hand, Israel was the third country in the world to be led by a female prime minister, Golda Meir, and in 2010, women's parliamentary representation in Israel was $18 \%$, compared to about $6 \%$ in Palestine and Jordan, and to $40 \%$ in Scandinavian countries.

In Palestine, the position of women is positive relative to most other Arab countries, be it that external conditions such as limited economic perspectives and traveling restriction 


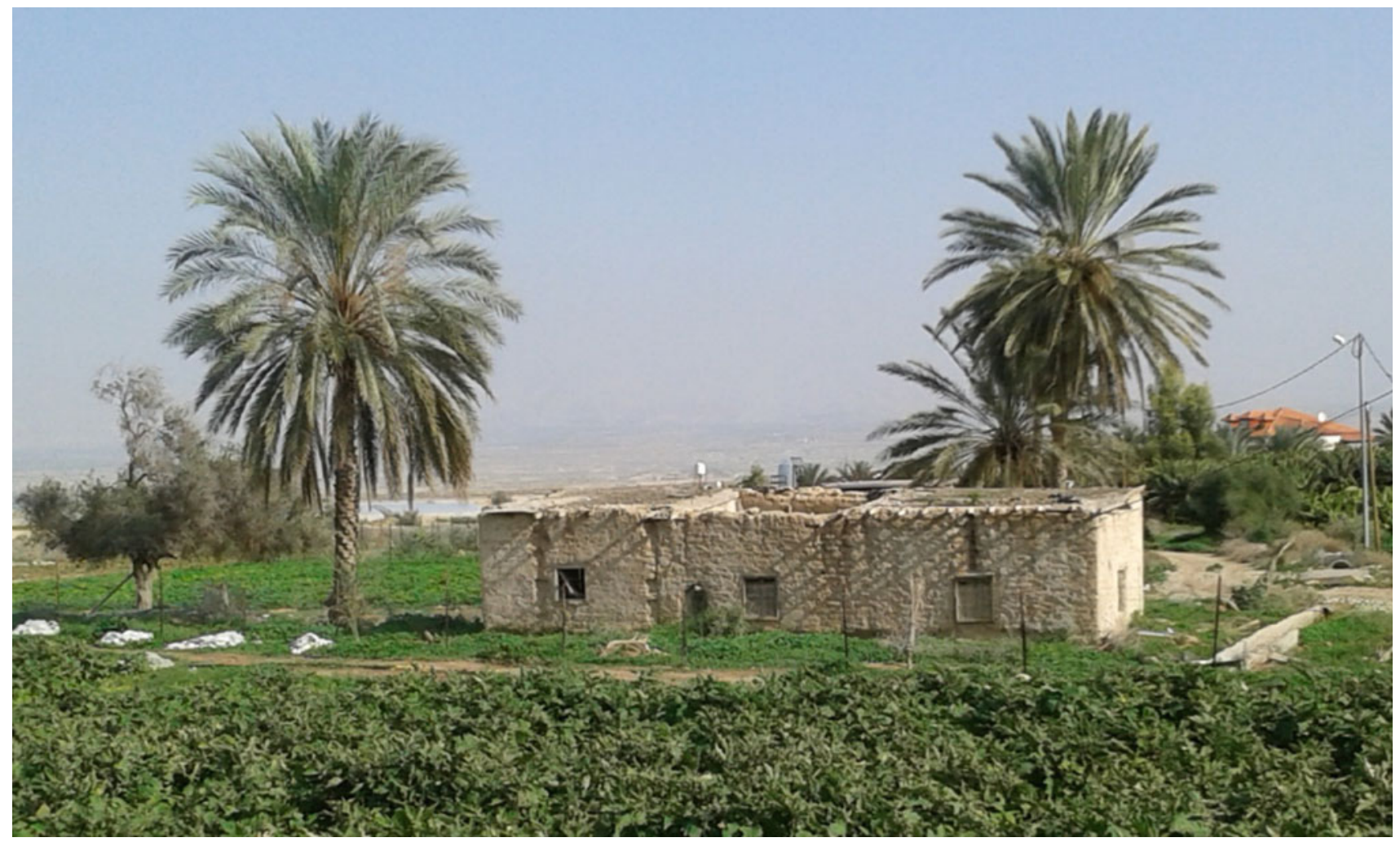

Fig. 2.20 Old farm house in the southern part of the Jordan Valley

imposed by the Israeli authorities are serious constraints for improving the position of women in the Palestinian society. In addition, Palestinian women still face some discrimination within Palestinian society itself. Despite high levels of education and activity within civil society, women remain underrepresented in public life, in part due to the societal norms that place pressure on women to conform to traditional gender roles. It has been difficult for Palestinian women during the previous decades to have their voices heard within a society that struggles with the occupation, putting justice for women on the backburner of the national agenda. However, the 2010 UNFPA report mentions that there is gradual improvement in gender roles and relations leading towards greater equality in Palestine (Fig. 2.20).

\subsubsection{Agriculture}

The Jordan Valley is divided into three distinct agricultural zones, because of different agro-climatic and ecological conditions. The northern zones on the West and East Banks receive more rainfall; have lower temperature and better soils. These conditions enabled the farming communities to cultivate field crops and tree crops under rain fed conditions. The middle and southern zones receive marginal rainfall; have poorer soils and higher temperatures and therefore higher evaporations. These zones are unsuitable for rain fed agriculture and Bedouin nomadic communities used to rear their goats and sheep flocks there. The altitude, climate, soil types, and water resources are different and unique for each of the agricultural zones.

The communities that farmed in the Jordan Valley had a reputation for the export of agricultural product to regional urban centers. The Arab-Palestinian communities, who are locally known as Al Ghawarna, were initially engaged in subsistence activities like herding, gathering and later cultivating cereals. Later they involved in the cultivation of wheat, barley, maize and vegetables, eventually irrigating these crops from water they obtained from rivers, streams, springs and wells inside the Jordan Valley and its side-wadis. In ancient documents the Al Ghawarna communities were praised for their irrigation practices and their capacities to export agricultural produce to urban centers in the region (Khouri 1981). Bedouins traditionally used the valley during winter months to forage their sheep and goats and then moved them to the fresher High Lands during the summer months.

In the 1950s, the riparian states developed a strong interest in irrigation development to expand the agricultural output of the Jordan Valley. The Government of Jordan started the construction of the East Ghor Canal in the late 1950s, which later became known as the King Abdullah Canal. This main 
canal flows on the East Banks and takes its water from the Yarmouk River and the streams flowing from the side-wadis of the Lower part of the Jordan River. The King Abdullah Canal supplies irrigation water to a series of irrigation schemes on the East Bank and to drinking water processing plants of urban centers in the High Lands of Jordan. The Government of Israel made major investments in irrigation development and the Carrier Canal enabled even irrigation development outside the Jordan Valley.

The development of a hydraulic revolution during the 1960s and 1970s has caused what El musa (1994) called a "Super Green Revolution" in the Israeli and Jordanian zones of the Jordan Valley. The expansion of the irrigated area and the successful application of Green Revolution technologies caused a boom to the production of high value crops like fruits and vegetables, which proved to be commercially highly profitable when exported to regional and European markets.

Due to the occupation of the West Bank, the Palestinians have missed out on large-scale irrigation development initiatives and continued to rely on small-scale irrigation initiatives around communally owned springs and privately owned wells. Israel controls the water resources in the West Bank and prevents Palestinians from drilling below certain depths. They create serious impacts onwater availiability by utilizing West Bank water resurces for settlemetns.

The riparian states applied very different policy and organizational concepts for the development and management of irrigated agriculture. On the East Bank the Government of Jordan established the Jordan Valley Authority (JVA) with the mandate to develop and manage the public owned irrigation systems and to carry out a land reform inside the command areas of the irrigation schemes. The JVA established a family farm model of 3.5 ha for the production of irrigated fruits and vegetables. The semi-public JVA organization allocated about 6,800 farm units inside the Jordan Valley study area to families of the indigenous Al Ghawarna and Bedouin farming communities and to investors from outside the valley, who were considered capable of developing and managing these resources intensive farms. A network of public and private sector irrigation and agricultural support service providers was established to assist these farming families to develop and manage on-farm irrigation systems, and to produce high value fruits and vegetables crops using the Green Revolution packages.

Irrigated agriculture in the Beit Shean agricultural-water zone developed through close collaboration between the public water agency, the cooperative farming enterprises (Kibbutzim) and the agricultural and irrigation support service providers of the public and private sector. Cooperative and family farms are the two main organization forms that are involved in primary agricultural production in the Beit Shean zone. Leaders of the Kibbutz movement were the driving force behind irrigation development in the Beit Shean zone because their farms controlled the land and water resources, and they had the vision, the technical and financial capacities and the required connections with the public water agency (Tables 2.8 and 2.9).

The Kibbutzim made substantial investments in research to develop the appropriate crops and cultivation techniques adapted for the specific physical and climatic conditions of the valley, and to cope with the increasingly stringent environmental and social standards of the export markets. With the agricultural sector investing in technical and commercial capacities to manage irrigation schemes and to practice irrigated farming, the public water agency could focus on the development and management of the main irrigation infrastructures and bulk water supply to organized agricultural water users.

Individual farmers were the driving force for the development of irrigated agriculture in the Palestinian zones. They

Table 2.8 Cultivated and irrigated land (ha) in the Jordan valley per zone in 2009/2010

\begin{tabular}{l|l|l|l}
\hline Zones & Administrative units & Cultivated land (ha) & Irrigated land (ha) \\
\hline Northern East Bank $* 2$ & Northern Shouneh District & 11,574 & 11,332 \\
\hline Northern West Bank $* 3$ & Beit Shean District & 17,820 & 10,430 \\
\hline Middle East Bank $* 2$ & Dair Al Alla District & 9,718 & 9,718 \\
\hline Middle West Bank $* 1$ & Tubas-Nablus Governorates (p) & 5,682 & 2,722 \\
\hline Southern East Bank $* 2^{\text {a }}$ & Southern Shouneh and (Ghor Safi) districts & 6,412 & 6,412 \\
\hline Southern West Bank*1 & Jericho and Al Aghwar Governorate & $(4,611)$ & $(4,611)$ \\
\hline Total & & 3,627 & 3,428 \\
\hline
\end{tabular}

Sources 1. PCBS Agricultural census 2010-Table 10 of Tubas/Nablus and Jericho and Al-Aghwar Governorates

2. DOS Agricultural census 2011-Al-Aghwar region

3. ARC: 2002: Table 3-3 and 3-4

${ }^{\mathrm{a}}$ The agricultural enterprises in the Ghor Safi District are located outside the study area but inside the service area of the King Abdullah Canal.

Therefore data on irrigated agriculture is included into this baseline report 
Table 2.9 Agricultural land use in the agricultural-water zones of the JORDAN VALLEY study area in 2011

\begin{tabular}{|c|c|c|c|c|c|c|c|}
\hline $\begin{array}{l}\text { Agricultural land } \\
\text { use }\end{array}$ & $\begin{array}{l}\text { Shouneh North } \\
* 1\end{array}$ & $\begin{array}{l}\text { Beit Shean } \\
* 3\end{array}$ & $\begin{array}{l}\text { Deir Alla } \\
* 1\end{array}$ & $\begin{array}{l}\text { Tubas/Nablus } \\
* 2\end{array}$ & $\begin{array}{l}\text { Jericho-Al } \\
\text { Aghwar *2 }\end{array}$ & $\begin{array}{l}\text { Shouneh } \\
\text { South*1 }\end{array}$ & $\begin{array}{l}\text { Ghor Safi } \\
* 1\end{array}$ \\
\hline *Fodder crops & 182.8 & 4,700 & 91.1 & 485.5 & 43 & 55.6 & \\
\hline *Field crops & 967.3 & 2,790 & 224.5 & 1,894 & 254.1 & 563.7 & 46.6 \\
\hline *Vegetables & & 8,160 & & $1,782.9$ & 2,630 & & \\
\hline -Open field & $2,763.3$ & & $3,463.4$ & & & $3,301.5$ & $4,537.8$ \\
\hline -Green houses & 918.7 & (20) & $2,124.6$ & & & 682.8 & 281 \\
\hline *Fruit crops & $6,698.2$ & 2,150 & $1,592.3$ & 397.7 & 700.7 & $2,135.4$ & 479.1 \\
\hline *Fish ponds & & 1,050 & & & & & \\
\hline *Fallow & $1,447.7$ & & $2,611.6$ & & & 351.1 & 133.6 \\
\hline$*$ Others $^{\mathrm{a}}$ & 105 & & 147.7 & & & 152.8 & 6.5 \\
\hline Total & 13,068 & 18,850 & $10,255.2$ & $4,560.1$ & $3,627.8$ & $7,242.9$ & $5,484.7$ \\
\hline
\end{tabular}

Sources *1 DOS 2011 Agricultural Census 2010-Table 5.1.1

*2 PCBS Agricultural Census 2010-Table 10 Tubas, Nablus and Jericho and Al Aghwar Governorates

*3 ARC 2002-Table 3-4

${ }^{\text {a }}$ The category others covers for example nurseries

manage the communal springs for their family or community groups and their private irrigation systems in case they controlled a well. The agricultural support service providers of the public and private sector are their knowledge partners. However the commercial farmers increasingly depended on the Israeli private service providers and the peasants on NGOs and their own experiments for agricultural development initiatives. The majority of farming households lacked irrigation facilities and on their smallholdings can only practice rain fed-agriculture and extensive livestock production.

Irrigated agriculture in the Jordan Valley focuses on the production of irrigated high value fruit crops and vegetables for the export markets. The growers have to meet the stringent standards of the export agencies, with a stress upon completely bug-free crops, controlled usage of chemicals and strict requirements for packing-houses and refrigeration. In the Israeli section of the study area the growers collaborated with national knowledge partners to develop appropriate cultivation techniques for the crops and livestock production systems. There is growing collaboration between the Israeli agribusinesses and the Palestinian commercial farmers for the production, processing and marketing of agricultural export products (Levy 2011). In the Jordan section of the valley the commercial farmers increasingly relied on the experts of the international agro-industries to deal with irrigated crop production technologies and the quality standards of export markets.

The livestock production systems play an important role in the mixed farming systems in the valley especially in the Israeli and Palestinian sections. The Kibbutzim and Moshavim in the Israeli zone of the study area were recorded to rear 9.500 cattle for dairy and beef production in 2002. The majority of the Palestinian farmers are involved in livestock production systems either in the mixed farming systems or their semi-nomadic livestock farming systems. In Jordan section of the valley livestock production is also considered economically relevance given the production of fodder crops (clover trefoil) and dairy products but no statistical data is collected concerning livestock production systems.

In the baseline report a distinction has been introduced between farming systems using high external inputs and low external inputs farming styles. The High External Inputs Agriculture or HEIA farming style applies the Green Revolution technologies, like chemical fertilizers, chemical control of weeds and pests, and genetically modified seeds. These inputs are produced externally to the farms by agro-chemical industries. LEISA farming style covers a series of practices that serve to reinforce ecological principles that are in line with local ecosystems. ${ }^{1}$ The Low External Inputs Sustainable Agriculture (LEISA) farming styles apply inputs that preferably are prepared internally of

\footnotetext{
${ }^{1}$ Low External Input Sustainable Agriculture (LEISA) is receiving increased attention of scientists and policy makers, both as a sustainable alternative to Green Revolution-technologies that make intensive use of internally produced inputs, and as a strategy of sustainable agriculture in resource-poor environments where no or very few external inputs are used. In areas with a high production potential, LEISA is considered to simultaneously improve ecological sustainability, food quality and farmers' socioeconomic conditions by minimal application of chemical inputs to reduce pollution of soil and water resources, chemical residuals in food, and financial incentives to increase labor production and ignore non-commercial functions of the agricultural sector. LEISA cover different set of agricultural practices that have different names (organic, ecological, bio-dynamic, and conservation agriculture (http:// www.odi.org.uk/sites/odi.org.uk/files/odi-assets/publications-opinionfiles/3143.pdf).
} 
their farms or partners' farms like manure and seeds and planting materials. The farmers use biological rather than chemical pest control techniques and mechanical weed control rather than herbicides. In Palestine LEISA production methods by family farms is dominant.

For this socio-economic baseline a classification matrix is applied that uses a farming style and a farm organization dimension. For farming styles the distinction between HEIA and LEISA technology is applies and for the farm organization the distinction is made between entrepreneurial, cooperative and family farms.

In Jordan, industrial farming is being developed by entrepreneurs and large groups of family farms specifically in the Middle Section of the LJV. Other farmers face the problem that farm units are fragmented and limited turn over to afford and and apply extensive technologies.

In Palestine, industrial farming is mainly done by the illegal Israeli settlement and by Palestinian entrepreneurs. The entrepreneurial, cooperative and family farms are distinguished on the ownership structure, the economic purpose of the farm and the labor recruitment strategy applied. The entrepreneurial farm is private property of the shareholders and its purpose is profit-making usually only in on-farm activities. $^{2}$ Therefore these farms are engaged in commodity production on the basis of commercial principles. The Palestinian cooperative farm is communal property of its members and its purpose is income generation for its members through on-farm and non-farm activities. The Israeli cooperative farm systems in the West Bank are all part of the illegal settlements and shall be removed by 2020 under the assumptions of this Master Plan. The family farm is private property usually of the family members in which social, economic, cultural and financial functions are combined. The purpose of the family farms is secured subsistence/income for the family members and therefore they engage in both subsistence and commodity production ${ }^{3}$ through on-farm and non-farm activities. Professional farm managers are in charge of the entrepreneurial and cooperative farms and they recruit laborers for the farm operations respectively through labor markets, and from the cooperative's members. They have to or try to pay market conform wages. However, the family farms recruit their labor from its members, who do not receive wages but subsistence security on the basis of solidarity within the family network.

\footnotetext{
${ }^{2}$ Profitability is considered an achievement or success criteria for the managed enterprise.

${ }^{3}$ Subsistence production deals with the production of use values, which are consumed by the producers themselves, while commodity production deals with the production of exchange values or products that are exchanged through market forces.
}

The HEIA and LEISA farming styles have beside distinct capital intensity level also different socio-technicalcommercial networks that serve them. The farms applying HEIA farming style have made high investments in intensive irrigated crops or livestock production systems. The HEIA farms get their technical and commercial support from upstream and downstream mainly private service providers often with production and marketing contracts for integrated service packages with agro-business companies or supermarket chains. The farmers applying the LEISA farming style use internally produced inputs and therefore are weakly connected with the external input suppliers: the agri-businesses and bio-technology companies. The peasants miss connections with the product markets, however the commercial family farms are connected to processors and market for environmentally and animal friendly produced food. In many countries public sector has established regulations and organizations, to supervise the trade and application of chemical inputs, which focus on the HEIA farming style. Usually LEISA farmers voluntarily abandon the use of chemical inputs and have consultation platforms with consumers/ environmental organizations and knowledge partners where the stakeholders decide jointly on guidelines and standards and supervision and labeling procedures of LEISA farming products (Tables 2.10, 2.11 and Fig. 2.21).

\section{Export of Agricultural products}

The Jordan Valley is the major agricultural production region for Jordan. On a national scale Jordan's agricultural export accounts for about 550 Million JOD (2014), mainly to the United Kingdom, The Netherlands, Canada, Germany, France, and to a lesser extend to Saudi Arabia and the Gulf States. The export increased by $12 \%$ compared to 2013 , and includes 888,000 tons of fruits and vegetables. About $85 \%$ of the export relates to vegetables, particularly tomatoes. In addition, Jordan exported 613,000 heads of cattle in 2014, mainly to the Gulf Region.

Israel is a major exporter of agricultural products as well as agricultural technologies. The Jordan Valley plays a minor role in the agricultural production, since the bulk is produced in the central and western regions of the country. Israel's agricultural exports account for about 2.2 Billion USD, or $4.2 \%$ of the total export. Vegetables account for about $24 \%$ of the total agricultural production. In

Table 2.10 Livestock in the Western Jordan Valley

\begin{tabular}{l|l|l|l}
\hline Animals & Beit Shean & Tubas & Jericho \\
\hline Dairy cattle & 3,600 & 640 & 1,030 \\
\hline Other cattle & 5,900 & 535 & 1,072 \\
\hline Goat and sheep & 1,000 & 14,000 & 67,000 \\
\hline Chicken & $1,000,000$ & 240,000 & 940,000 \\
\hline Other (horse and donkey) & & 20 & 320 \\
\hline
\end{tabular}


Table 2.11 Classification matrix of farm organizations and farming styles in the Jordan Valley

\begin{tabular}{l|l|l}
\hline $\begin{array}{l}\text { Farming style } \\
\text { farm } \\
\text { organization }\end{array}$ & High external input agriculture (HEIA) & Low external input sustainable agriculture (LEISA) \\
\hline $\begin{array}{l}\text { Entrepreneurial } \\
\text { farm }\end{array}$ & $\begin{array}{l}\text { Capital intensive farms controlling moderate to large } \\
\text { holdings where specialized crop and livestock production } \\
\text { systems are practiced using hiring specialized farm } \\
\text { managers and wage laborers }\end{array}$ & No information available yet \\
\hline $\begin{array}{l}\text { Cooperative } \\
\text { farm }\end{array}$ & $\begin{array}{l}\text { Capital intensive farms controlling large holdings } \\
\text { specialized in intensive crop and livestock production } \\
\text { systems using the management and labor capacities of the } \\
\text { cooperative's members }\end{array}$ & No information available yet \\
\hline Family farm & $\begin{array}{l}\text { Widespread in family farms practicing specialized irrigated } \\
\text { crop productions for which they depend on external } \\
\text { upstream and downstream flow of commodities. These } \\
\text { farmers had to take loans and engaged in production and } \\
\text { marketing contracts to minimize risks are commonly called } \\
\text { farmer'. }\end{array}$ & $\begin{array}{l}\text { Widespread in family farms practicing mixed and } \\
\text { subsistence farming and who want to control the internal } \\
\text { resource base and to avoid risks of commercial loans. The } \\
\text { farmers that focus on subsistence food production are } \\
\text { commonly called 'peasants'. }\end{array}$ \\
\hline
\end{tabular}

Fig. 2.21 Greenhouses in the Jordan Valley

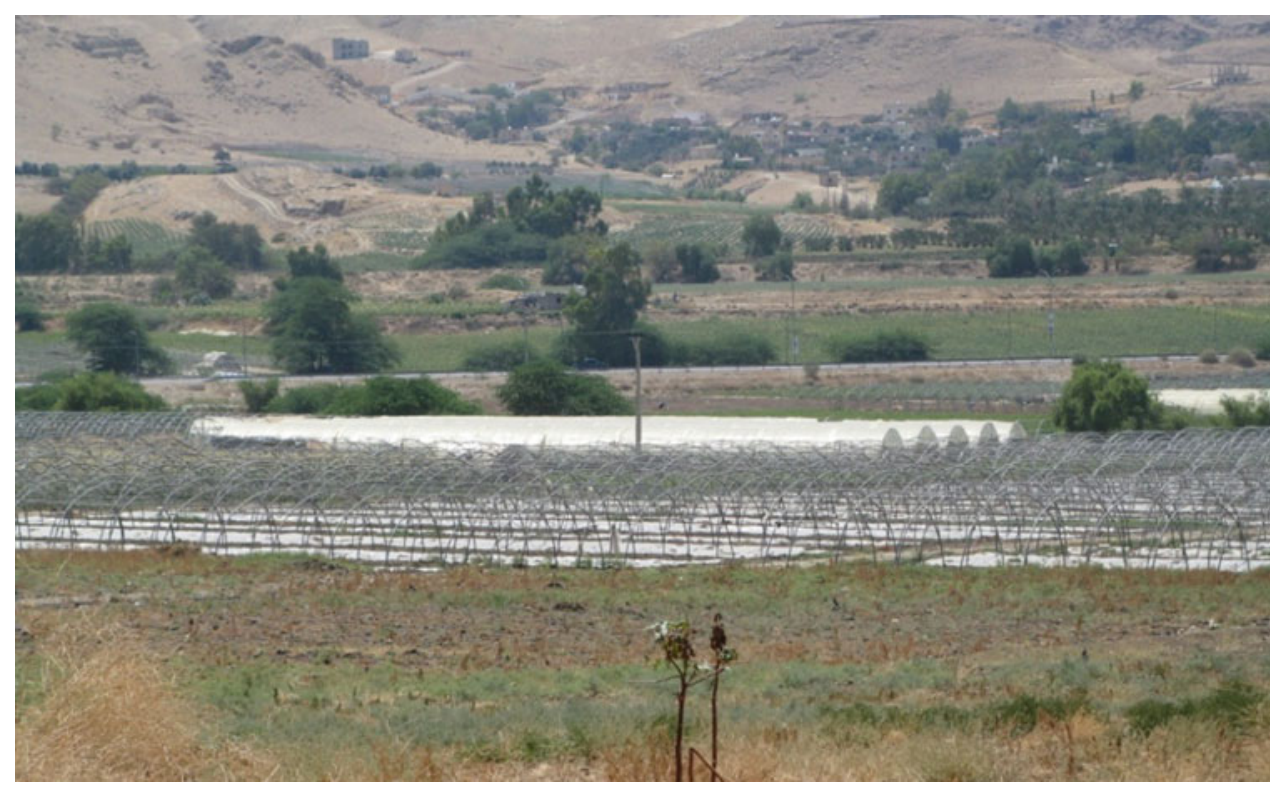

addition, Israel produces about 690,000 tons of fruits, including 190,000 tons of citrus fruits for export, as well as wheat, barley, corn and cotton. Supporting services, including post harvesting, scientific research and agro-industry are highly developed in Israel. In addition, Israel produces $95 \%$ of its own food requirements, supplementing this with imports of grain, oilseeds, meat, coffee, cocoa and sugar.

The total annual Palestinian exports account for about 900 Million USD in 2013. The agricultural sector contributes today to about $4.5 \%$ of Palestine's GDP, compared to $13 \%$ in 1993, with the Jordan Valley playing a very modest role. This decline largely relates to increasing transport restrictions, agricultural land confiscations and limited control over most of the agricultural lands situated in the areas C. Most of the agricultural production is for domestic consumption and local markets, and only limited amounts are exported. About 5.3 Million USD of fruits and 5.9 Million USD of meat products were exported in 2013. More than half goes to Jordan, followed by Europe, Algeria and the United States (Fig. 2.22).

\subsubsection{Tourism}

The Jordan Valley has considerable tourism potential and offers numerous historical, scenic and religious attractions. Tourism contributes between 7 and $14 \%$ to the economy of the three countries. Tourism in the Jordan Valley is strongly linked to the unique geographic features and its historic, 


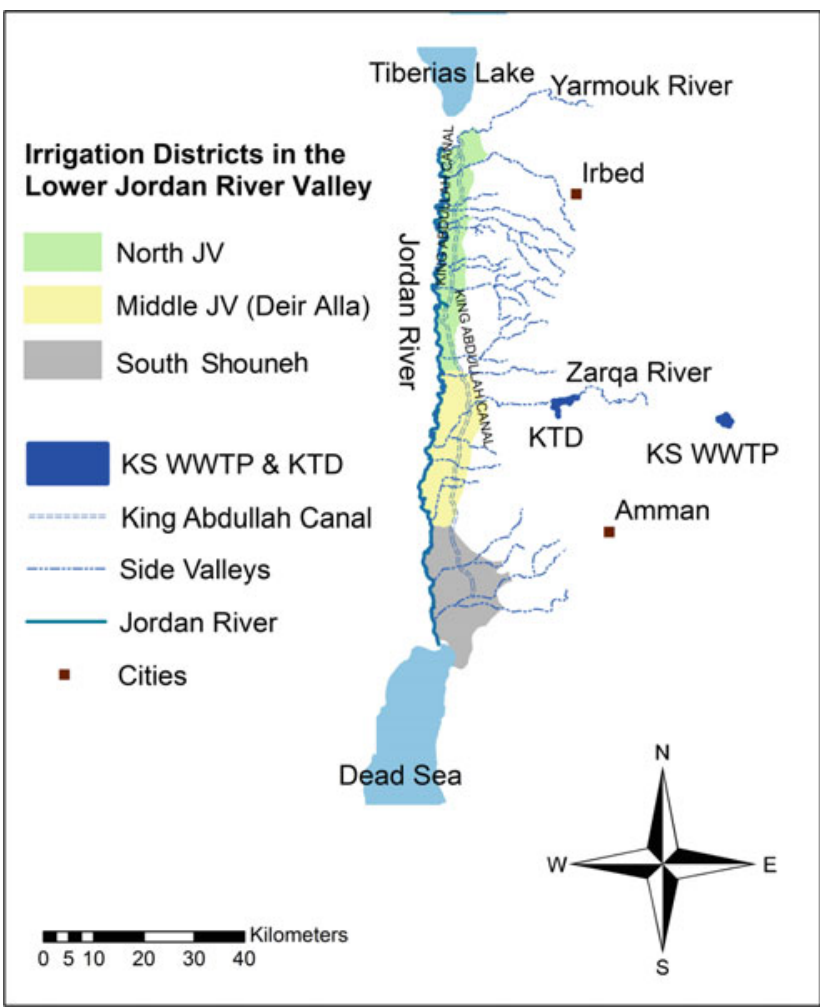

Fig. 2.22 Agricultural zones in the Jordan Valley (Jordan)

religious, cultural and archeological features in the valley. Tourist destinations include health/spa tourism, nature areas, and cultural heritage (including religious) sites. Many international tourists combine a day trip to the Jordan Valley as part of their overall vacation itinerary. In addition, nationals of the three countries see the Jordan Valley as a popular trip destination during weekends or holidays.

However, tourism facilities are still relatively undeveloped in the Jordan Valley. The potentials in terms of recreation, thematic site visits and touristic tours are huge. The Jordan Valley is the home of a unique combination of tourist attractions. The archaeological and biblical sites have been described earlier in this report. The Jordan River is one of the sacred places, both historically and symbolically, for Moslems, Jews and Christians throughout the world. In addition, the flora and fauna inside the valley are very diverse as a consequence of the area's particular geological and climatic conditions. Potentials to be further developed could include hiking or biking along the Jordan River and Dead Sea Trails, camping, rock climbing and boating in dam waters along the LJR or in the Jordan River itself. Other potentials could be religious tours such as a Pilgrims Path of the Companion of the Prophets (Islamic tour), the Hajj Trail (regional tour), a journey in the Footsteps of Moses, John, and Jesus in the Land of Moab, and many others. In addition, there could be potentials for deepening the linkages between established tourism accommodations and rural communities, such as organizing excursions and traditional meals in Arab and Bedouin communities, guided tours to nature reserves and bird watching, and horse and camel riding in the desert.

Further the Jordan River feeds the Dead Sea, which has no outlet and has the geographical reputation as "the lowest point on earth," lying almost $430 \mathrm{~m}$ below sea level. This results in high evaporation and in extremely high contents of salt and other minerals. Swimming in the Dead Sea water is beside a special experience also considered to have curative effects for skin and respiratory diseases. Finally, half a billion of migratory birds fly twice yearly through the Jordan Valley moving from their breeding grounds in North and West Europe and their wintering grounds in South and East Africa. This diversity of tourist attractions gives the Jordan Valley the potentials to become one of the main tourist destinations in the Middle East Region.

However, to develop these potentials the riparian states will have to create a supportive policy environment through constructive collaboration. The tourism sector is very sensitive to the regional political tensions and the number of tourists decline sharply when disputes escalate. Although tourists become more adventure-oriented, they avoid destinations where they consider that their safety is at risk. The socio-political developments in Middle East with its growing encounters between political and religious fractions and alliances had negative effects on the Jordan Valley's reputation as a diverse and safe tourist destination.

Table 2.12 provides an indication of the main tourism indicators in the Jordan Valley. These figures are based on information from the Jordanian Ministry of Tourism and Antiquities (2010), the Israeli Ministry of Tourism and Antiquities (2012) and the Palestinian Ministry of Tourism and Antiquities (2011), supported with data from the national central bureaus of statistics and some assumptions.

In Israel, $29 \%$ of foreign tourists, about $58 \%$ of them being people with a Christian background, define their trip as a pilgrimage, which most likely include a trip to the Baptism site at Yardenit along the Jordan River. There is a total of approximately 588,700 visits to the Yardenit site in the Jordan Valley, mostly on a day trip basis from Tiberias or Jerusalem.

The Baptism site in Jordan is visited by about 80,000 foreign tourists per year, while Mount Nebo, along the boundary of the Jordan Valley is visited by 394,993 foreign visitors and 1566 Jordanian nationals per year. The Dead Sea in Jordan is visited by 16,873 foreign visitors and 7,072 local visitors annually. Based on these figures it has been assumed that a total of about 491,000 foreign tourist visit the Jordanian study area on an annual basis.

Jericho, which is the main urban center in the Palestinian part of the study area with about 34,000 inhabitants, 
Table 2.12 Jordan Valley tourism indicators (2010)

\begin{tabular}{|c|c|c|c|c|c|c|}
\hline \multirow{2}{*}{ Indicator } & \multicolumn{2}{|l|}{ Jordan (2010) } & \multicolumn{2}{|l|}{ Israel (2012) } & \multicolumn{2}{|c|}{ Palestine (2011) } \\
\hline & Nation & $\mathrm{JV} *$ & Nation & $\mathrm{JV} *$ & $\begin{array}{l}\text { Nation/West } \\
\text { Bank }\end{array}$ & Jericho and $\mathrm{JV}^{*}$ \\
\hline $\begin{array}{l}\text { Foreign visitors per } \\
\text { year }\end{array}$ & $3,644,267$ & 491,000 & $3,500,000$ & 588,700 & $2,200,000$ & 750,000 \\
\hline $\begin{array}{l}\text { Local visitors per } \\
\text { year }\end{array}$ & 451,444 & 8,638 & 500,000 & 50,000 & $2,700,000$ & 250,000 \\
\hline $\begin{array}{l}\text { Number of hotels } \\
\text { available }\end{array}$ & 487 & 28 & 340 & 53 & 93 & 12 \\
\hline $\begin{array}{l}\text { Number of beds } \\
\text { available }\end{array}$ & 46,141 & 2,496 & 95,800 & 1,235 & 2,167 & 800 \\
\hline $\begin{array}{l}\text { Number of hotel } \\
\text { guests }\end{array}$ & & & & & 264,000 & 34,000 \\
\hline $\begin{array}{l}\text { Bed nights- } \\
\text { foreigners }\end{array}$ & $4,557,024$ & 24,651 & $10,000,000$ & 80,000 & 220,000 & 30,000 \\
\hline $\begin{array}{l}\text { Bed nights- } \\
\text { nationals }\end{array}$ & $?$ & $?$ & $12,000,000$ & 40,000 & & \\
\hline $\begin{array}{l}\text { Revenues from } \\
\text { tourism }\end{array}$ & $1.01 \mathrm{~B} \mathrm{JD}$ & $11.1 \mathrm{M} \mathrm{JD}$ & 9 B USD & 12 M USD & $250 \mathrm{M}$ USD & 5-10 M USD \\
\hline $\begin{array}{l}\text { Employees in } \\
\text { tourism sector }\end{array}$ & 41.900 & 2266 & 105,000 & 100 & 10,000 & 200 \\
\hline Main tourism season & $\begin{array}{l}\text { July, August, } \\
\text { Sept }\end{array}$ & $\begin{array}{l}\text { Easter, July, } \\
\text { August, Sept }\end{array}$ & $\begin{array}{l}\text { July, August, } \\
\text { Sept }\end{array}$ & $\begin{array}{l}\text { Easter, July, } \\
\text { August, Sept }\end{array}$ & $\begin{array}{l}\text { July, August, } \\
\text { Sept }\end{array}$ & $\begin{array}{l}\text { Easter, July, } \\
\text { August, Sept }\end{array}$ \\
\hline
\end{tabular}

*JV In the Jordan Valley, excluding Dead Sea

Italic Best estimate

welcomes around 1.1 Million daily visits and 34,000 hotel guests per year. Assuming that the tourist sector in Jericho counts for about $14 \%$ of the Gross Domestic Product, as for the rest of Palestine in the West Bank, and taking into account a per capita GDP of 1,036 USD, this leads to an estimated revenues for the tourist sector in the Palestinian study area of around 5-10 M USD per year.

The two main hotel resorts in Jericho are the 4 stars Jericho Resort with 104 rooms and 254 beds, and the 5 stars Intercontinental Jericho Hotel with 181 rooms and 362 beds. The large amount of inbound tourism in Palestine (over $60 \%$ of inbound daily visits and over $90 \%$ of inbound overnights) is faith based Christian tourism. The Palestinian citizens of Israel visit Palestine in a considerable daily visits as well as overnights are recorded. They made the top most daily visitors and made the third most overnights. Tourist coming from USA, Germany, France, Korea and some other like Britain and Norway create a growing demand for tourism in Palestine. The tourists often combine their trip to Jericho with visits to archaeological sites, historic features as well as the cultural and natural landscape in the Jordan Valley.

As indicated in Table 2.12, the Jordan Valley between the Sea of Galilee and the Dead Sea is visited annually by about 1.33 million foreign visitors, including 491,000 foreign visitors in the Jordanian part of the study area; 588,000 foreign visitors in the Israeli part of the study area, and approximately 250,000 foreign visitors in the West Bank part of the study area. In addition, it is estimated that a total of 70,000 local nationals visit the study area for recreational purposes annually.

Most visitors come to the area on a one-day basis. Only about $1 \%$ of foreign visitors stay overnight in the study area, leading to approximately 134,000 Bed Nights per year in the study area. Most of the international tourists have night accommodation in other parts of the region, mostly in Amman, Jerusalem and Tel Aviv.

The revenues from tourism in the study region cannot be separated sharply from the national tourist revenues. Direct revenues in the region include hotel and restaurant costs, local travel costs, purchase of goods and souvenirs and admission fees to various sites and attractions. Indirect revenues relate international flights, day trips to wider parts of the region, and the theoretical percentage of tourists that decide to come to the one of the three countries for reasons directly related to touristic sites in the Jordan Valley.

It is estimated that approximately $1 \%$ of the total tourism revenues within Jordan is directly earned in the study area, or about 11 million Jordanian Dinars out of approximately a total tourism related national revenue of 1 billion JD. The tourism sector in Israel is the largest of the region, with 9 billion USD of revenues per year (2013). The portion earned 
directly in the study area is only a fraction of this. It is estimated that 12 million USD or $0.1 \%$ is directly earned from tourism in the study area.

For the Palestinian part of the study area the situation is more complicated, since the Palestinians have no access to the major portions of the West Bank, and many visitors to for instance the Baptism Site in the West Bank are served by tourist operators from elsewhere in Israel. It is the Consultant's estimate that the direct Palestinian earnings from tourism in the study area is about 5 million USD, against a total Palestinian income from the tourist sector in the West Bank of about 250 million USD [ref. Ministry of Tourism and Antiquities.

\subsubsection{Industry}

With the exception of the Israeli zone, the industrial sector is inadequately developed in the Jordan Valley. In Jordan agriculture related services include industries supplying greenhouses, on-farm water management equipment and agricultural inputs. An initiative was taken to develop a fruits processing plant; however it failed in the opinion of many farmers.

In Palestine the agro-industrial linkages are also weak. The HEIA farms have connections with the agro-industries in Israel that provide irrigation equipment and external inputs. The forward linkages are weak, because the products are directly sold to the consumers or the suppliers in the urban environment that have processing capacities.

The agricultural sector in Israel has established strong backward and forward linkages through the Kibbutzim's organization structures. The economic scales of the kibbutz farms enabled mechanization of the farm operations and investing in processing capacities for its main products through clusters of Kibbutzim. Kibbutzim alone or jointly could invest in technical and managerial capacities needed for backward industrial services, like the production and installation of drip irrigation systems, or in forward industrial services like the processing and marketing of milk or fruit products. The cooperative structure enabled the Kibbutzim organization to invest in agro-industrial initiatives that had synergies with their farm activities through the valorization of its products and for making more efficient use of the labor resources of its members during the off-season of the on-farm activities (Fig. 2.23).

The Jordanian section of the Jordan Valley houses a number of mainly small industrial operations, including:

- The Wadi Rayyan Free Zone, between Pella and Karamah, including a gold and jewel factory.

- The AMPC Tomato Paste Factory.

- The Pella Trading Gypsum Board plant;

- The Indian Jordanian Chemical Company;

- Insustrong Polystyrene Factory south of El Arda;

- A small polystyrene factory between Sleikhat and Karn;

- The Jordan Plastics Factory at Facku Rama; and the Jordan Fertilizer Company north of Arda; and

- The Travertine Company Ltd. (TRAVCO) located in the Middle Jordan Valley at Fanoush-Ghor Damia.

Agricultural developments in the Jordan Valley had strong links with the service sector but contributed marginal to industrial development. Sophisticated water management equipment is imported from Israel, India, and European countries to gain comparative advantage with water saving and treatment of wastewater. Jordan has an advanced position in the production of phosphate and potash fertilizers but
Fig. 2.23 Stone cutting workshop and car workshop near Moath Bin Jabal

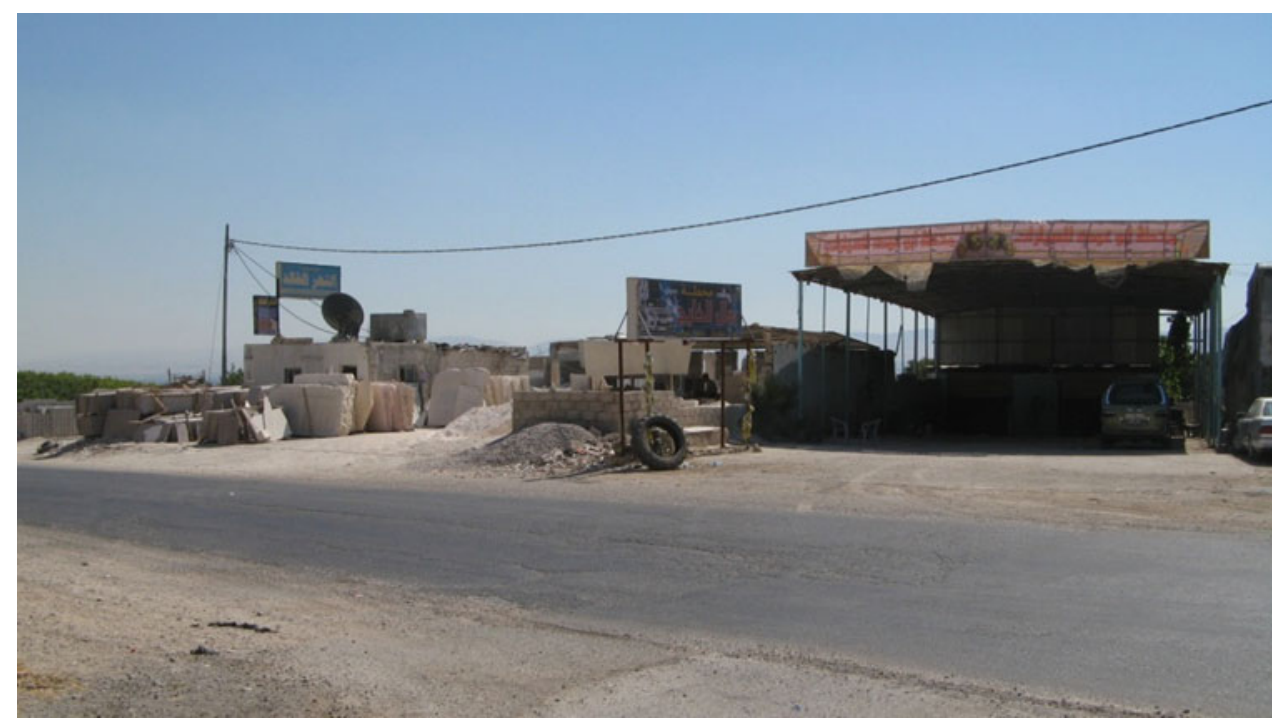


the plants are in Aqaba because of the transport advantages. USA and European agri-business companies dominate the markets for agricultural seeds and chemical inputs. Many of these international companies have their headquarters in Amman with one sales and service office in the valley.

Agriculture processing industries have a poor base in the Jordan Valley. Fruits and vegetables production is focused on fresh products directly sold to the Jordanian consumers or exported. During the 1980s the Jordanian Government invested in the establishment of a processing plant for fruits and vegetables with support of the European Union. The processing plant was established in Dair Al Alla, and the Department of Industries and a local organization of commercial farmers jointly managed it for the production of tomato paste. The farmers liked the plant since it enables them to process their low-grade tomatoes and delay the sale of their products when prices dropped too much. Farmer leaders have the opinion that management of the plant deteriorated after the Jordanian Government ousted the farmer representatives from the management and sold the plant to a foreign private investor, who was interested in its assets. The remaining agro-industries are small-scale family enterprises for the processing of minor agricultural products like grains, olives and dates.

The backward linked industries in the East bank consist predominantly of small industries for the construction sector and package industry. There are several quarries that produce materials for the construction of buildings and infrastructures in the north-eastern governorates of Jordan. Some quarries export marble. There are also several metal processing plants in the central and southern part of the East Bank that produce metal frameworks for greenhouses and install these for commercial farmers. Small plants are spread over the East Bank that produce wooden and plastic crates and boxes for the commercial farmers, for packing their produce in accordance with the demands of the export markets.

Other industrial sites in the study area include small stone quarries, cement production, pumps, tubes, pipes, textiles, leather, furniture, paper, printing, chemicals, metals, mechanical and electrical equipment, and transport.

In Israel, Beit Shean is a regional center of fish-farming and fruit trees cultivation. Many residents of the Beit Shean district are members and employees of Kibbutzim that initially focused on farming activities but have diversified during the past decade in backward and forward linked industries to their farming activities. The industrial non-farm activities of these cooperatives cover production and installation of water management equipment (e.g. rain water collection and drip irrigation), fish processing and marketing capacities, processing and marketing of fruits and dairy products.
In November 2013, Israel and Jordan agreed on construction of a multimillion-dollar joint industrial zone on the border between Israel and Jordan near Beit Shean. This is considered to be the first large-scale economic co-operation project since the peace treaty was signed in 1994. It is foreseen that the Israeli section of the park will include offices, warehouses, export and trade-related activities, while the Jordanian section will include various large scale industrial production complexes.

The park will consist of two parallel industrial and employment zones connected by a bridge spanning the Jordan River. From both sides, only authorized personnel and visitors will be allowed to enter while Israeli law will apply to the Israeli side and Jordanian law to the Jordanian side. A new governmental body called the Jordan Gateway Authority will be created to oversee activity on the Israeli side of the park. Movement of employees from both nationalities within the Park will not be restricted.

However, there are serious environmental concerns related to this project because of its chosen location on pristine land on the banks of the River Jordan. WEDO/EcoPeace proposes to reconsider the site location and move it to land adjacent to the existing crossing point at Sheikh Hussein Bridge.

In Palestine, the key existing industrial activities are located in Jericho: aluminum windows and doors, bricks, clothes, iron products, meat processing, metal windows and doors, plastic packing materials, tiles, Tannery, and wooden furniture. Furthermore there are well advanced plans for the realization of the Jericho Agro-Industrial Park (JAIP), including common solar power supply, waste supply and wastewater treatment facilities. The area will have a size of 11.5 ha and will be operated as a Public-private enterprise. Palestinian companies, mainly small- and medium-sized business, are offered financial concessions, including tax cuts, to lease plots of land in the park to process agricultural products that can be sold in the West Bank and abroad. All investors will have access to risk insurance from the Multilateral Investment Guarantee Agency, set up by the World Bank to protect them against negative impacts of conflict situation with the Israelis. The project is coordinated by the Palestinian Industrial Estates and Free Zones Authority (Piefza), based in Ramallah, backed by a grant of about $\$ 47.7 \mathrm{~m}$ from the Japan International Co-operation Agency (JICA), which is paying for the solar power system, the installation of a sewerage and water system in the park, plus support from Japanese engineers. PRICO has been appointed as park developer, and so far around 20 businesses-from Palestine and Jordan, and one Arab-Israeli company-have expressed interest in setting up business on the Park. The park's objective is to eventually generate as much as $\$ 41.6 \mathrm{~m}$ turnover per year and create more than 3,700 jobs. 


\subsubsection{Human Water Demands and Supply}

The human water demands in the study area have been divided into two categories: domestic/industrial and agricultural water demands. The calculated domestic/urban demands include all household, industrial, institutional, commercial and tourism water demands. An assessment has been made of the current domestic/industrial water demands based on the available population data in the year 2010, and per capita water requirements. For the sake of uniformity these per capita water requirements have been set throughout the valley at $90 \mathrm{~m}^{3}$ per capita per year.

Agricultural water demands in the valley have been assessed on the basis of agricultural land use, current cropping patterns and crop water requirements. Particularly for Jordan, which is by far the largest agricultural water consumer in the study area, a distinction has been made between vegetables in the open field; vegetables in green houses, fruit trees and field crops. The agricultural water demands have been defined on the basis of currently utilized agricultural lands, and do not include potential agricultural lands that have not been developed so far.

Water demands for livestock, fish farming and industrial activities have been made on the basis an assessment of their current size and extension in the study area, in combination with data from earlier work done by the Austrian Research Centre in their water resources management study for the Jordan. Valley.

The total water demands are not fully met by actual water supply figures. In general the valley experiences a gap between the required water demands and the actual water supply, as elaborated below as well. Table 2.13 provides a summary of the total human water demands in the Jordan Valley in 2010.

Water demands are fulfilled directly by water from the Sea of Galilee, and should therefore be added to annual water resources available in the Jordan Valley.

\section{Domestic Water Demand}

The domestic water demand has been calculated using the assessment of the current valley population and the regional domestic water use per capita presented in Table 2.13. The per capita domestic water demands are very variable between the three riparian states and between the urban and rural populations (Fig. 2.24).

For the assessment of the current domestic water no differentiation has been made between the lower per-capita water consumption in rural villages and the higher consumption in urban agglomerations, and all in annual per-capita water demand is assessed at $60 \mathrm{~m}^{3}$ per person per day in Jordan and Palestine, and $90 \mathrm{~m}^{3}$ per person per day in Israel for the year 2010.
Table 2.13 Assessment of the human water demand in the Jordan Valley in 2010

\begin{tabular}{|c|c|c|c|}
\hline \multicolumn{3}{|c|}{$\begin{array}{l}\text { Total domestic water demands } \\
\text { Jordan }\end{array}$} & 2010 \\
\hline & \multicolumn{2}{|c|}{ Northern Jordan Valley District } & $6,536,580$ \\
\hline & \multicolumn{2}{|c|}{ Deir Alla } & $4,075,500$ \\
\hline & \multicolumn{2}{|c|}{ South Shouneh } & $4,217,640$ \\
\hline & \multicolumn{2}{|c|}{ Informal population (according to JVA) } & $7,410,000$ \\
\hline & \multicolumn{2}{|c|}{ To Amman } & $60,000,000$ \\
\hline & \multicolumn{2}{|l|}{ Total } & $82,239,720$ \\
\hline \multicolumn{3}{|c|}{$\begin{array}{l}\text { Total agricultural water demands } \\
\text { Jordan }\end{array}$} & 2010 \\
\hline & \multicolumn{2}{|r|}{ Zone 1 (115,300 dunum) } & $103,596,865$ \\
\hline & \multicolumn{2}{|r|}{ Zone 2 (74,959 dunum) } & $107,169,170$ \\
\hline & \multicolumn{2}{|r|}{ Zone 3 (120,835 dunum) } & $65,492,271$ \\
\hline & \multicolumn{2}{|r|}{ Total } & $276,258,306$ \\
\hline \multicolumn{3}{|c|}{$\begin{array}{l}\text { Total domestic water demands } \\
\text { Israel }\end{array}$} & 2010 \\
\hline & & Emek Hayarden & 990,000 \\
\hline & & Emek Hamaayanot & 990,000 \\
\hline & & Beit Shean & $1,530,000$ \\
\hline & & Hagilbo'a & 900,000 \\
\hline & & Total & $4,410,000$ \\
\hline \multicolumn{3}{|c|}{$\begin{array}{l}\text { Total agricultural water demands } \\
\text { Israel }\end{array}$} & 2010 \\
\hline & & Jordan Valley WA & $21,237,000$ \\
\hline & & Afikey Main WA & $52,015,000$ \\
\hline & & Harod WA & $22,000,000$ \\
\hline & & Fish ponds & $100,000,000$ \\
\hline & & Total & $195,252,000$ \\
\hline \multicolumn{3}{|c|}{$\begin{array}{l}\text { Total domestic water demands (CM/year) } \\
\text { Palestine }\end{array}$} & 2010 \\
\hline & inians & & \\
\hline & & Bardala Cluster MD & 315,540 \\
\hline & & Al-Nassariya Cluster MD & 273,840 \\
\hline & & Al-Jiftlik Cluster MD & 389,940 \\
\hline & & Fasayil Cluster MD & 69,420 \\
\hline & & Al-Auja Cluster MD & 265,380 \\
\hline & & Jericho MD & $2,046,720$ \\
\hline & & Subtotal Palestinian & $3,360,840$ \\
\hline & nents & & \\
\hline & & Cluster North MD & 128,250 \\
\hline & & Cluster Central MD & 356,400 \\
\hline & & Cluster South MD & 77,400 \\
\hline & & Subtotal Israeli Settlers & 562,050 \\
\hline & & Total & $3,922,890$ \\
\hline
\end{tabular}

(continued) 
Table 2.13 (continued)

\begin{tabular}{l|l|l}
\hline $\begin{array}{l}\text { Total agricultural } \\
\text { Palestine }\end{array}$ & 2010 \\
\hline Palestinians & Bardala Cluster & \\
\hline PAD 1 & Al-Nassariya Cluster & $10,558,755$ \\
\hline PAD 2 & Al-Jiftlik Cluster & $5,240,855$ \\
\hline PAD 3 & Fasayil Cluster & $5,400,437$ \\
\hline PAD 4 & Al-Auja Cluster & $1,173,919$ \\
\hline PAD 5 & Jericho & $3,991,597$ \\
\hline PAD 6 & & $11,082,381$ \\
\hline Settlements & Cluster North AD & \\
\hline IAD 1 & Cluster Central AD & $3,100,095$ \\
\hline IAD 2 & Cluster South AD & $36,621,768$ \\
\hline IAD 3 & Total & $8,000,662$ \\
\hline & & $85,170,469$ \\
\hline $\begin{array}{l}\text { Grand total water demands Jordan Valley } \\
\text { (CM/year) }\end{array}$ & $647,253,385$ \\
\hline
\end{tabular}

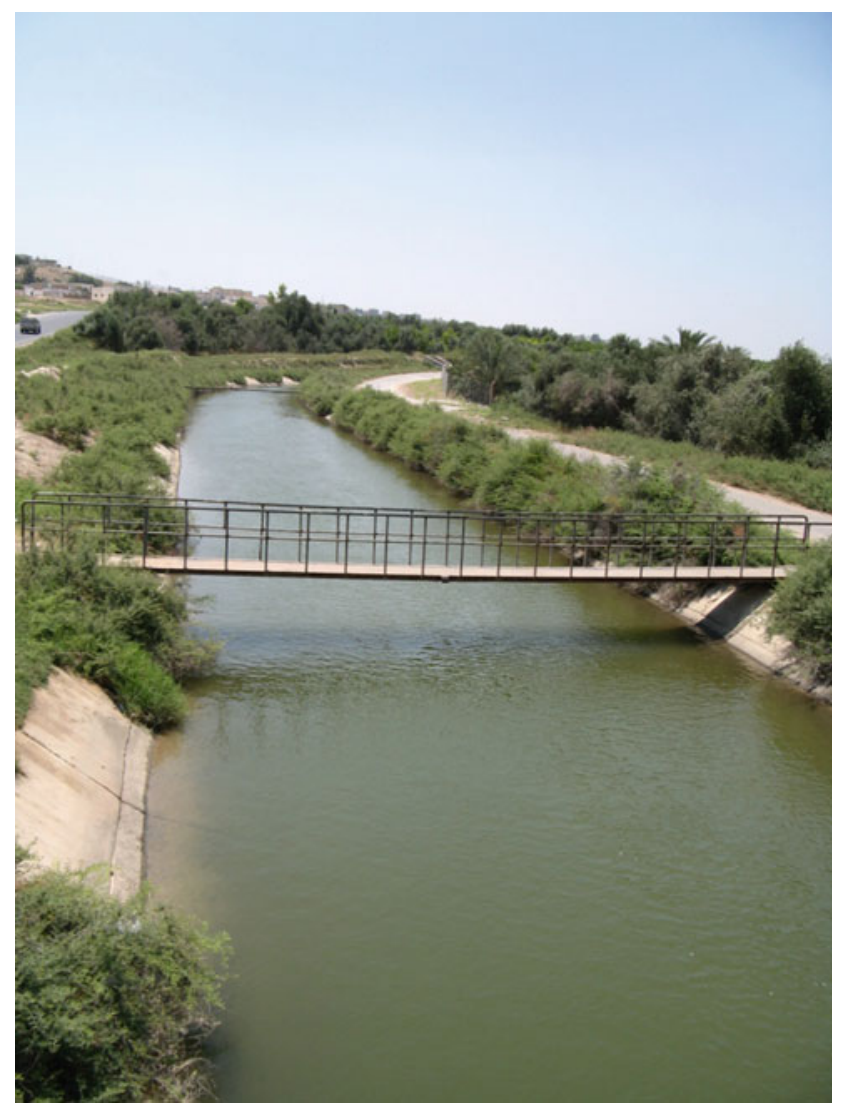

Fig. 2.24 King Abdullah Canal

\section{Industrial Water Demand}

There are few industrial activities in the valley. Only one location has been established in Beit Shean municipality and two locations have been planned inside the valley. One location is planned on the East Bank near the Sheik Hussein Crossing and another near Jericho. No information about type of industries and their water demands can be made yet because the private sector considers investments too risky in the current hostile political and economic environments. The water demand from industry is low and the ARC and its partners estimated the industrial water usage as less than $1 \mathrm{MCM} / \mathrm{year}$ in the valley, with most of it being used in the Beit Shean region (ARC 2003).

\section{Agricultural Water Demand}

For agricultural water demand a distinction is made between the water requirements of the crops, animal husbandry, fishery production systems that form integral components of the farming systems in the valley. Crop production systems dominate the farming systems in the Jordan Valley. However, the combination of crop and livestock production systems is prominent in the farming systems both in the Israeli and Palestinian section of the West Bank. Processing facilities inside the farming systems are only relevant in the Israeli section of the study area and their water demands are considered under industrial water demands.

The calculation of irrigation water demands for crop production depends on many factors such as climatic conditions and soil types, crop-specific requirements, the efficiency of irrigation systems and the operation system applied by the irrigation managers. As the Jordan Valley have different transitional climates with different precipitation and evaporation rates for the northern and southern zones of the valley. Accordingly, the crops grown in the different zones have also differentiated water requirement parameters. However the irrigation systems are managed on demand-basis during the winter season when supplementary irrigation is practices and on supply-basis during the summer season when the available water resources dictate how these should be most efficiently. This sub-section only introduces the human water demand issues since the results of the water resources management scenario and modeling exercise will be presented in a separate report.

Statistical data for irrigated crops production have been provided for the study area by the organizations managing or supervising the management of water resources. The project partners provided data about the monthly crop water demands in the different agricultural zones. See Table 2.15. 


\section{Fish Ponds Water Demands}

Fishponds are pivotal to understanding the local consumption and water balance in the LJR. On average, a fishpond requires 3-6 MCM/year per $\mathrm{km}^{2}$. Since most of the ponds in the area were constructed without lining, water losses by percolation are estimated at $20-50 \%$ of the water put in the ponds, most, if not all finds its way to the LJR. Another 40$50 \%$ is lost to evaporation and the rest is discharged back to the river as saline polluted effluent.

Israel operates the majority of the fish ponds in the study area. The surface area of fishponds in the region totals to about 20,000 dunums, which means a combined consumption of approximately $120 \mathrm{MCM} / \mathrm{year}$. Most of the fishponds$16.8 \mathrm{~km}^{2}$, are concentrated around Harod Stream and in Emeq Hamaayanot. Fish cultivation is periodical with most of the effluent being discharged in October-December. In Emeq Hamaayanot there is also some discharge in January-February. These fish ponds are supplied with water from a series of reservoirs. The reservoirs serve a dual purpose of operational storage and fish cultivation. Each reservoir is designated for a specific water quality. For example, the AMWA maintains a total storage capacity of $32 \mathrm{MCM}$ as follows: $5 \mathrm{MCM}$ for fresh water (under $500 \mathrm{mg} / \mathrm{L}$ Chlorine), $2 \mathrm{MCM}$ for treated wastewater (WW) - namely from the newly built WWTP of Beit Shean, which produces 0.7 MCM/year; $25 \mathrm{MCM}$ for saline water that come from local springs. The main fish ponds in the Israeli part of the study area are:

- Gesher Fish Ponds, about 560 dunum, consuming about $2 \mathrm{MCM} / \mathrm{year}$ of water taken from the Jordan River

- Never Ur and Hamadia Fish Ponds, about 1100 dunum in total, consuming about 16.9 MCM/year from the Jordan River. These ponds are rather old, with high percolation rates towards the groundwater.

- Emek Hamaayanot Fish Ponds, about 10,000 dunum in total, consuming $50 \mathrm{MCM} / y e a r$. These ponds also serve as reservoirs for saline water irrigation

\section{Demand Versus Supply}

Whereas the water demands are based on estimated requirements on the basis of the current population, economic activities and existing agricultural areas, the water supply figures represent an assessment of the actual 2010 water supply throughout the valley. The difference between the two represents water shortages for the various (current) water users in the valley.

The combined domestic and industrial water demands have been set at assessed at $60 \mathrm{~m}^{3}$ per person per day in Jordan and Palestine, and $90 \mathrm{~m}^{3}$ per person per day in Israel for the year 2010. This is based on the actual water demands in the valley in Jordan, Israel and Palestine. It has been assumed that actual water demands in Jordan would be of a similar level, assuming that water availability would be adequate. The agricultural water demands have been calculated on the basis of current agricultural land use and crop water requirements on a monthly basis.

The actual water supply figures are based on the information obtained from the major water supply authorities and associations in the valley, notably the Jordan Valley Authority (JVA) and Water Authority of Jordan (WAJ); the Israeli Jordan Valley Water Association, the Afikey Maim Water Association; the Harod Water Association, Mekorot, and the Palestinian Water Authority.

Specifically the water use of Israeli settlements in the Palestinian study area represents sensitive information that generates a lot of discussions. The UNOCHA for instance claims that the settlements consumption of water in the West Bank is about four times higher than the Palestinians water consumption. In the below table the Consultant estimated various water uses in the study area, based on total population numbers, agriculture field areas and crop water requirements within the study area. An overview of the total water demands versus supply in the valley is provided in the above table.

The total water supply in Jordan from the Jordan Valley has been estimated to be approximately $269 \mathrm{MCM} / \mathrm{year}$ (2010). It should be noted that the water supply includes conveyance of $60 \mathrm{MCM}$ of water per year from the King Abdullah Canal to Amman through the Deir Alla Diversion, leading to an actual water supply within the valley of $209 \mathrm{MCM} /$ year, compared to $299 \mathrm{MCM}$ of total water demands within the valley. This implies that approximately $70 \%$ of the total water demands are actually supplied.

Based on the information obtained, the water demands within the study area in Israel, the water demands in Israel are fully met in terms of actual water supply. This means that the current population, economic activities and existing agricultural areas in this area are fully supplied with the water they need. Again, this is based on the current water users in the valley, and does not include potential water demands related to new economic, agricultural or urban development ambitions that there may be.

Domestic water supply to the Palestinians in the study area is derived from the groundwater aquifer systems, a series of springs that emanate from the aquifers, and minor amounts of surface runoff in addition to purchased water from Mekorot and from cisterns. The estimated unaccountant for water, defined as water that is either lost through leakages of is not paid for, is estimated to be about $25 \%$. Irrigated agriculture takes mainly place in Wadi Fara'a in and in Jericho region.

Most of the water resources in the Palestinian part of the study area are utilized for water supply purposes. Runoff into the Jordan River is limited to some storm water runoff from 
Wadi Fara'a, which is estimated to be about 6.4 MCM/year, mainly as a peak flow sometime during the months of January or February.

The total water supply in the Palestinian part of the Jordan Valley study has been estimated to be approximately $82 \mathrm{MCM} /$ year (2010). This includes $34 \mathrm{MCM} / \mathrm{year}$ for the Palestinians and $48 \mathrm{MCM}$ for the Israeli settlements in the Palestinian study area. The water demands of the Israeli settlements are supposed to be supplied fully. The Palestinian water demands have been estimated to be $42 \mathrm{MCM}$. This implies that approximately $80 \%$ of the total Palestinian water demands are actually supplied. This is based on the current population numbers and utilized agricultural lands. This does not include potential agricultural lands that are structurally not utilized due to the limited water resources.

\subsubsection{WEAP Model for the Jordan Valley}

WEAP is based on the principle of closing the water balance in a basin, in order to understand the balance between the total water resources on the one hand, and the total water consumption on the other hand, leading to a model for the monthly and annual flows in the Lower part of the Jordan River, as well as the salinity levels in the river. The hydrological year taken in this study starts at October 1st until September 30th of the next year, with monthly model steps in between. The model strives to describe the current situation (current accounts) of one average year, which is this WEAP model runs from October 1st 2009 until September 30th 2010. Runoff is defined here as surface water flow that reached the LJR, which is the direct result of a rain event. Salinity is the only indicator of water quality.

Direct contribution of groundwater to the LJR from Israel (north of Bezeq Stream) was calculated according to Holtzman, who quantified groundwater in two segments of the LJR, between the Yarmouk and Harod Stream. The model simulates groundwater contribution, by adding groundwater inflow in two reaches: below the Yarmouk and below Issachar. The annual contribution of groundwater into the LJR was estimated to be $18 \mathrm{MCM}$, with an average salinity of $1150 \mathrm{mg} / \mathrm{L}$. In the West Bank (south to Bezeq stream) direct information on the connection between the groundwater system in the Jordan Valley and the Lower part of the Jordan River has been described in some studies. In the current WEAP model it has been assumed that groundwater inflow is constant throughout the year and is based on flow measures performed at Qasr El Yahood (5-6 MCM/month).

In the East Bank, the shallow groundwater system consists of lacustrine sediments and Clastic fluvial components. The aquifer has been developed largely since the 1960s, and many shallow wells have been drilled, largely for irrigation purposes. Consequently, groundwater levels have dropped and salinity levels increased substantially. Where historically groundwater flow in the Eastern Jordanian valley area had a westwards direction, today more water is abstracted that recharged naturally. In this model it has therefore been assumed that there is no annual contribution of groundwater into the LJR from the Jordanian side.

The current accounts run of the WEAP model for the hydrological year 2010 confirms that within the limits of the currently available water resources, the Jordan Valley is subject to structural water shortages. This is particularly the case for the agricultural water users in Jordan and Palestine and to a lesser extend for Israel.

\section{Jordan}

As outlined in Table 2.14, the total Jordanian water demands in the study area have been assessed at $298 \mathrm{MCM}$ /year, of which $268 \mathrm{MCM}$ is supplied through the various sources described above. Particularly the agricultural sector suffers from shortages, whereas these shortages become more severe along the southernmost stretches of the King Abdullah Canal. These shortages are closely linked to the overall water balance in Jordan, and the increasing demands from other parts of the country, particularly the urban area of Amman. Currently, Amman receives already $60 \mathrm{MCM}$ of water per year from the sources of the Jordan Valley. This situation puts a clear cap on future agricultural and economic aspirations in the Jordan Valley. It will be required to find solutions that require less water, or reducing unaccounted for water percentages against higher benefits per unit of production.

\section{Israel}

The Israeli water demands, as well as supplies, have been assessed in the study area at $220 \mathrm{MCM} /$ year. Similarly, there seems not much room for further expansion of water depending economic or agricultural activities. It should be noted that fish ponds use a large portion of the available water resources, about $120 \mathrm{MCM} /$ year. Finding methods to reducing this share, and meanwhile reducing their environmental impacts on the Lower part of the Jordan River, seems to be one of the major challenges for the coming years. Recent developments such as releasing more water from the Sea of Galilee into the LJR as result of the growing Israeli reliance on desalinated coastal water may provide an outlook to the direction where solution could be found to relieve the water stress in the Jordan Valley in the future.

\section{Palestine}

The Palestinians have limited control over their lands and water resources in the West Bank, except for Area A around the city of Jericho. The water demands of the Palestinians that currently live in the study area have been assessed at $42 \mathrm{MCM} /$ year of which $34 \mathrm{MCM}$ is actually supplied. In addition about $48 \mathrm{MCM}$ of water is supplied from the 


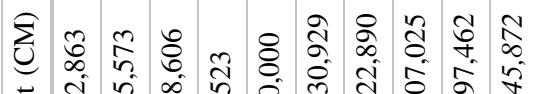

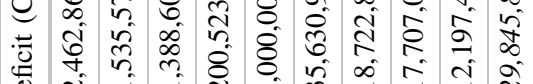

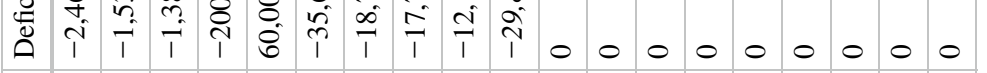

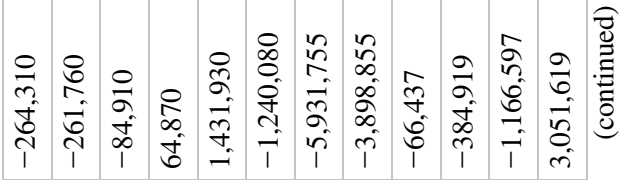

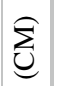

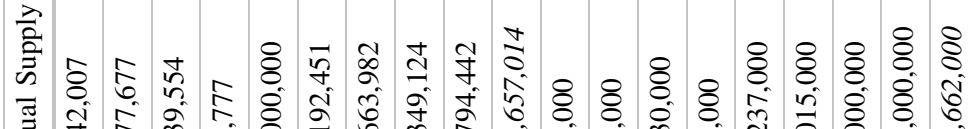

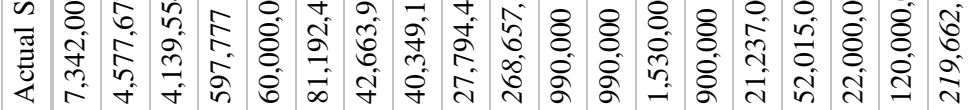

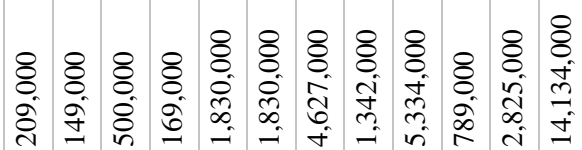

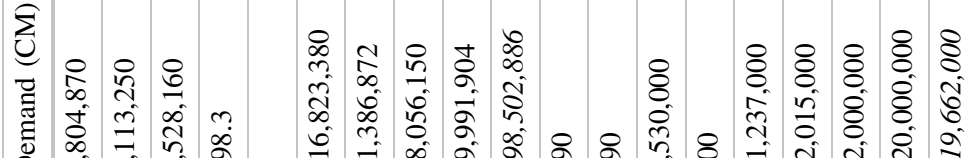

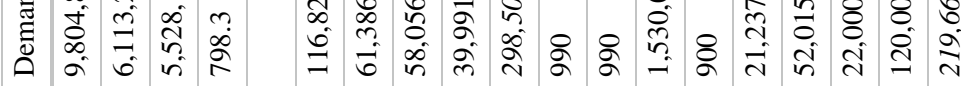

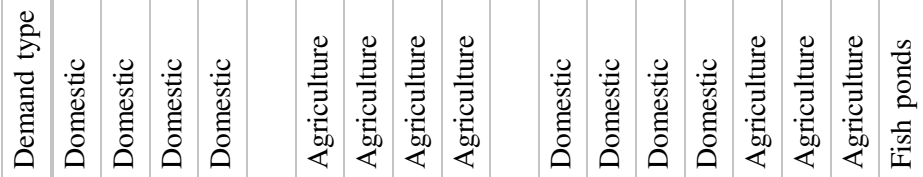

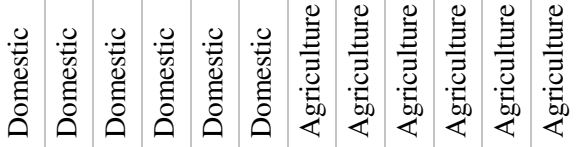

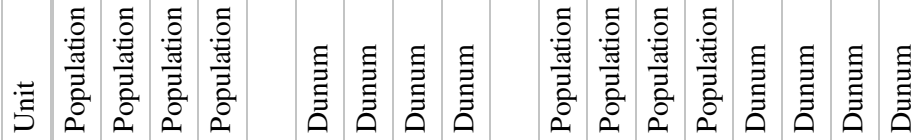

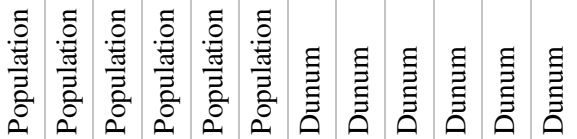

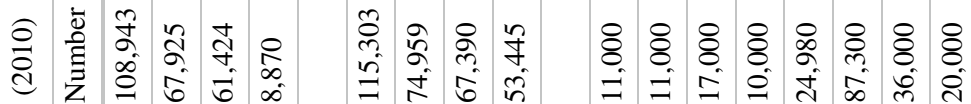

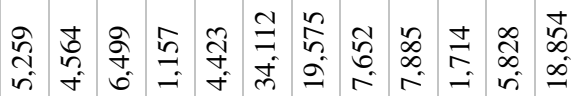

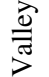

苞

焉

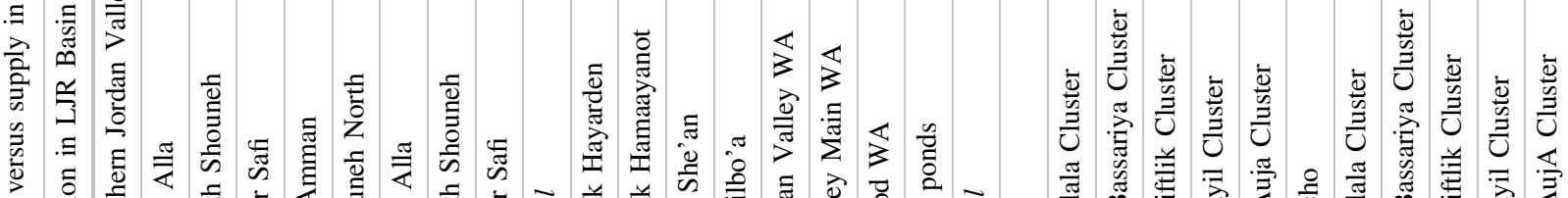

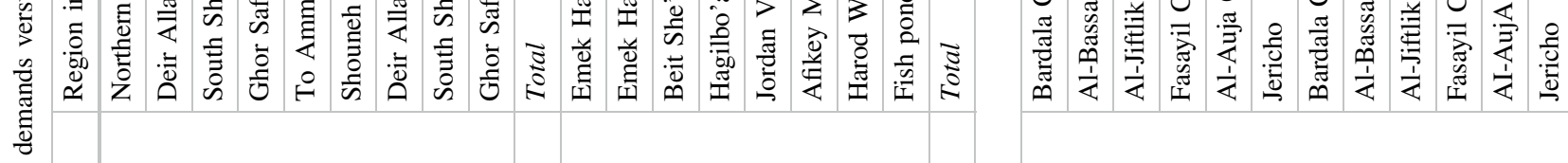

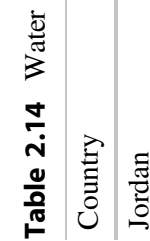

$\sqrt{3}$

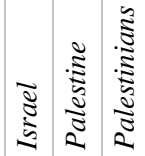




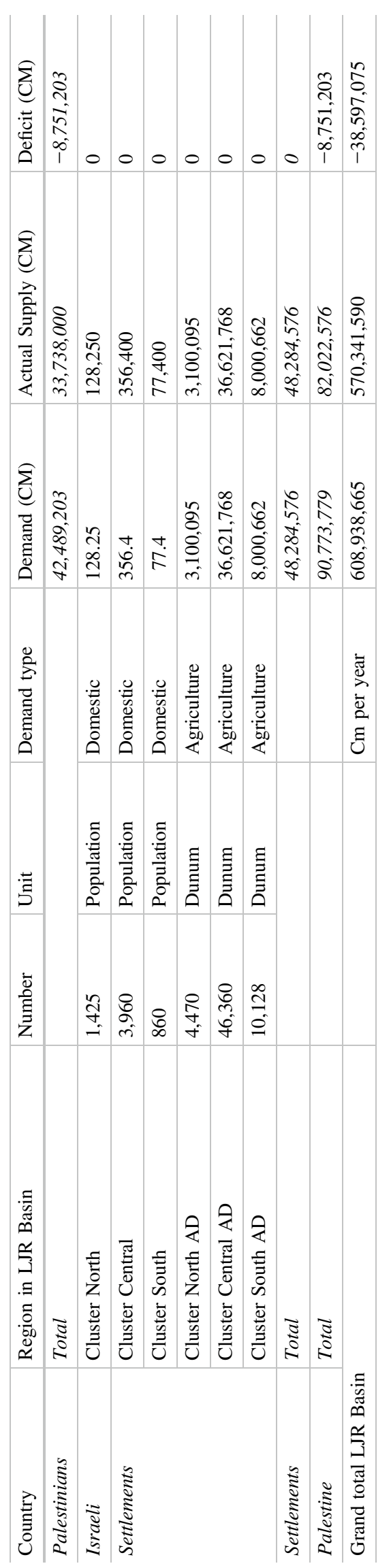


locally available water resources to the Israeli settlements. These figures show clearly the development limitation for the relative small number of about 56 thousand Palestinians that still live in the area, set aside any larger economic or agricultural ambitions that the Palestinians may have. Solutions for the Palestinian water stress lay largely in the political arena and the current Peace Negotiations with Israel, and should include securing the comprehensive Palestinian control and management of their water resources, including the ground and surface water originating inside Palestine, in addition to respecting the riparian rights of the Palestinians as equal partners in the Jordan Valley.

\section{Lower part of the Jordan River}

The current account run of the WEAP model clearly shows the impacts of these water demands on the Lower part of the Jordan River itself. Below tables show the calculated monthly and annual water flows along different spots in the river, and their related salt concentrations for the hydrological year of 2010: The annual flow in the northern section of the LJR is only $22 \mathrm{MCM}$ at the point where the Saline Water Carrier enters the river, and consequently the salinity levels are high with $2,409 \mathrm{mg} / \mathrm{L}$ salt. Near the Bezeq Stream the flow slightly increases to about $80.5 \mathrm{MCM} /$ year with $1,448 \mathrm{mg} / \mathrm{L}$ of salt. When it finally meets the Dead Sea the flow has reached a maximum with about 102.5 MCM/year. Clearly, these values don't meet any of the criteria for lifting the river to a healthy ecological status, and concise interventions will be needed, starting with preventing salt and pollution inflow into the river and mitigating their polluting sources, and next finding sustainable and sensible solutions for a steady increase of the river's base flow.

\subsection{It's Governance}

\subsubsection{Stakeholders in the Jordan Valley}

Stakeholders can be identified furthermore on various criteria: power, support, influence and importance. There is a correlation between the stakeholders' interest in the consultation issue and their support or lack of support for the project initiative. The stakeholders' interest in the consultation issue can change during the consultation process and a stakeholder can become more or less supportive towards the initiative. Balancing between economic and environmental interests of various stakeholders is a sensitive process. Therefore, the identification and selection of the stakeholders is a critical step that influences the constituencies of the Master Plan as it was developed.

Irrigated agriculture is a core economic activity in the Jordan Valley and therefore stakeholders are distinguished for the agricultural, the water and the environmental sectors.
Concerning Integrated Water Resources Management the stakeholders representing the agricultural and environmental interests take very divergent opinions and it is hoped that through interactions they start to take more convergent positions. Exclusion or inclusion of stakeholders for the consultations can have far-reaching consequences on the discussions and the compromises reached through the negotiations, but also for the constituency of the plans. For the identification of the stakeholders a distinction will be made between public, private and voluntary organizations, keeping in mind that these are the three societal pillars of effective water governance systems. Special attention has been given to the stakeholders that have a positive influence on the consultations through the formulation of compromises based on common needs of stakeholders with perceived antagonist's interests.

\section{Jordan}

For the water sector in Jordan, the Ministry of Water and Irrigation, the Jordan Valley Authority and the Jordan Water Authority are recommended to represent the public sector. Representatives of the Water Users Associations, the Southern Shouneh Chambers of Commerce represent respectively the agricultural and industrial water users in the consultations. Of the NGOs in Jordan EcoPeace Middle East has developed various water related initiative in the Valley and therefore is representative the voluntary sector. Four WUA representatives in the Forum's Steering Committee have represented all WUAs in the consultation process during preparation of this Jordan Valley NGO Master Plan.

For the agricultural stakeholders in Jordan, the Ministry of Agriculture, NCARE and ACC represent the public sector. The Jordan Farmers Unions, the Irbid and Southern Shouneh Chambers of Commerce and the Fruits and Vegetables Association represented the private sector organizations. Of the environmental NGOs, the Jordan Environmental Society is working on tensions between economic and environmental issues in relation to irrigated agriculture. In the agricultural sector of the Jordan Valley representatives of the three major tribal clans have to be involved to obtain a critical mass among farmers. Unfortunately there is not yet a farmer's organization for the promotion of LEISA production techniques that could represent the interests of this sub-group of farmers, which the HEIA farmers might not allow the Jordan Farmers Union to do.

The Southern Shouneh Chamber of Commerce and the Dead Sea Tourist Board represent the private sector organizations. Of the environmental NGOs, the Royal Society for the Conservation of Nature and the Jordan Environmental Society have been both involved in the discussions about sustainable development and natural resources management initiatives. 


\section{Israel}

For the water sector in Israel, the Ministry of Energy and Water Resources, the Israeli Water Authority on a local scale, and the Jordan Valley Water Association, the Afikey Maim Water Association and the Harod Water Association, as well as the Kinneret Drainage Authority and Lower Jordan River Drainage Authority (Israel) represent the public sector in the study area. The environmental sector at governmental level is represented by the Ministry of Environmental Protection, the Israel Nature and Parks Authority INPA. The tourism sector is represented by the Ministry of Tourism (Tables 2.15, 2.16, 2.17, 2.18, 2.19, 2.20, 2.21 and 2.22).
The Israeli local communities are represented by the Jordan Valley Regional Council and the Valley of Springs Regional Council, who provide various municipal services in the region, as well as Beit Shean Municipality as one of the major cities in the study area.

\section{Palestine}

The main public sector stakeholders involved Integrated Water Resources Management in the Palestinian zones are the National Water Regulator, the Palestinian Water Authority, the Ministry of Agriculture and the Environmental Quality Authority. On December 14th 2009, the Cabinet of Ministers of the Palestinian National Authority

Table 2.15 Stakeholders representing the Jordanian Water Sector

\begin{tabular}{|c|c|c|}
\hline Sectors & $\begin{array}{l}\text { Formal organizations that have been identified } \\
\text { as representatives of stakeholders groups }\end{array}$ & Groupings involved in the Jordan Valley NGO master plan initiatives \\
\hline $\begin{array}{l}\text { Public } \\
\text { sector }\end{array}$ & $\begin{array}{l}\text {-Ministry of Water and Irrigation } \\
\text {-Jordan Valley Authority } \\
\text {-Jordan Water Authority }\end{array}$ & \multirow[t]{2}{*}{$\begin{array}{l}\text { (MoWI and WUAs participate in the Jordan Valley Water Forum that the } \\
\text { World Bank Institute facilitates) }\end{array}$} \\
\hline $\begin{array}{l}\text { Private } \\
\text { sector }\end{array}$ & $\begin{array}{l}\text {-Water users Associations } \\
\text {-Irbid Chamber of Industry }\end{array}$ & \\
\hline $\begin{array}{l}\text { Voluntary } \\
\text { sector }\end{array}$ & -EcoPeace Middle East Jordan Valley network & $\begin{array}{l}\text { Women organization that represents the women as stakeholder in water and } \\
\text { environmental services in the residential areas of the Jordan Valley }\end{array}$ \\
\hline
\end{tabular}

Table 2.16 Stakeholders representing the Jordanian Agriculture Sector

\begin{tabular}{|c|c|c|}
\hline Sector & $\begin{array}{l}\text { Formal organizations that have been identified } \\
\text { as representatives of stakeholders groups }\end{array}$ & Groupings involved in the Jordan Valley NGO master plan initiatives \\
\hline $\begin{array}{l}\text { Public } \\
\text { sector }\end{array}$ & $\begin{array}{l}\text {-Ministry of Agriculture } \\
\text {-National Centre for Agricultural Research and } \\
\text { Extension } \\
\text {-Agricultural Credit Corporation }\end{array}$ & \\
\hline $\begin{array}{l}\text { Private } \\
\text { sector }\end{array}$ & $\begin{array}{l}\text {-Jordan Farmers Union } \\
\text {-Irbid and Southern Shouneh Chambers of } \\
\text { Commerce } \\
\text {-Fruits- and Vegetables-Exporters Association }\end{array}$ & $\begin{array}{l}\text { Representatives of El Wakid, El Ghezawi and El Adwan clans representing } \\
\text { the Al Ghawarna family farmers }\end{array}$ \\
\hline $\begin{array}{l}\text { Voluntary } \\
\text { sector }\end{array}$ & $\begin{array}{l}\text {-Jordan Environmental Society Jordan Valley } \\
\text { Branch Office }\end{array}$ & $\begin{array}{l}\text { Grouping of LEISA family farms that has as objective to promote } \\
\text { environment-friendly agriculture production technologies in the JORDAN } \\
\text { VALLEY }\end{array}$ \\
\hline
\end{tabular}

Table 2.17 Stakeholders representing the Jordanian Recreation and Environmental Sectors

\begin{tabular}{l|l}
\hline Sector & Formal organizations that have been identified as representatives of stakeholders groups \\
\hline Public sector & $\begin{array}{l}\text {-Ministry of Tourism } \\
\text {-Ministry of Environment }\end{array}$ \\
\hline Private sector & $\begin{array}{l}\text {-Southern Shouneh Chamber of Commerce } \\
\text {-Dead Sea Tourism Board }\end{array}$ \\
\hline Voluntary sector & $\begin{array}{l}\text {-EcoPeace Middle East Amman Office } \\
\text {-Jordan Hashemite Fund for Human Development (JOHUD) } \\
\text {-Royal Society for the Conservation of Nature } \\
\text {-Jordan Environmental Society Jordan Valley branch }\end{array}$
\end{tabular}


Table 2.18 Stakeholders representing Israel

\begin{tabular}{|c|c|c|}
\hline Sectors & $\begin{array}{l}\text { Formal organizations that have been identified as } \\
\text { representatives of stakeholders groups }\end{array}$ & $\begin{array}{l}\text { Groupings involved in the Jordan Valley NGO master plan } \\
\text { initiatives }\end{array}$ \\
\hline $\begin{array}{l}\text { Public } \\
\text { sector }\end{array}$ & $\begin{array}{l}\text { Ministry of Energy and Water Resources } \\
\text { Israeli Water Authority } \\
\text { Kinneret Drainage Authority } \\
\text { Lower Jordan River Drainage Authority } \\
\text { Ministry of Environmental Protection } \\
\text { Israel Nature and Parks Authority } \\
\text { Ministry of Tourism } \\
\text { Ministry of Agriculture } \\
\text { Israel Land Authority } \\
\text { Ministry of Defense } \\
\text { Airports Authority -Land Border Control } \\
\text { Ministry of Transportation } \\
\text { National Economic Council-Prime Minister's Bureau. } \\
\text { Ministry of Finance } \\
\text { Ministry of Regional Cooperation } \\
\text { Ministry of Galilee and Negev Development }\end{array}$ & \multirow[t]{3}{*}{$\begin{array}{l}\text { Representatives of authorities and users groups with respect } \\
\text { to land, water, environment }\end{array}$} \\
\hline $\begin{array}{l}\text { Local } \\
\text { communities }\end{array}$ & $\begin{array}{l}\text { Valley of Springs Regional Council } \\
\text { Jordan Valley Regional Council } \\
\text { Beit Shean Municipality }\end{array}$ & \\
\hline $\begin{array}{l}\text { Private } \\
\text { sector }\end{array}$ & $\begin{array}{l}\text { Water users Associations } \\
\text { Chamber of Industry }\end{array}$ & \\
\hline $\begin{array}{l}\text { Voluntary } \\
\text { sector }\end{array}$ & $\begin{array}{l}\text { EcoPeace Middle East Tel Aviv office } \\
\text { Society of Protection of Nature of Israel } \\
\text { Zalul } \\
\text { Jewish National Fund }\end{array}$ & \\
\hline
\end{tabular}

Table 2.19 Stakeholders representing the Palestinian Water Sector

\begin{tabular}{l|l|l}
\hline Sector & $\begin{array}{l}\text { Formal organizations that have been identified } \\
\text { as representatives of stakeholders groups }\end{array}$ & Groupings involved in the Jordan Valley NGO master plan initiatives \\
\hline $\begin{array}{l}\text { Public } \\
\text { sector }\end{array}$ & $\begin{array}{l}\text {-Water Sector Regulatory Council } \\
\text {-Palestinian Water Authority } \\
\text {-Jericho Municipality }\end{array}$ & \\
\hline $\begin{array}{l}\text { Private } \\
\text { sector }\end{array}$ & $\begin{array}{l}\text {-Water users Associations } \\
\text {-Jericho Chamber of Industry }\end{array}$ & \\
\hline $\begin{array}{l}\text { Voluntary } \\
\text { sector }\end{array}$ & $\begin{array}{l}\text {-EcoPeace Middle East-Bethlehem office } \\
\text {-PHG } \\
\text { - House of Water }\end{array}$ & $\begin{array}{l}\text { Women organization that represents the women as stakeholder in water and } \\
\text { environmental services in the residential areas of the Jordan Valley }\end{array}$ \\
\hline
\end{tabular}

Table 2.20 Stakeholders representing the Palestinian Agriculture Sector

\begin{tabular}{l|l|l}
\hline Sector & $\begin{array}{l}\text { Formal organizations that have been identified } \\
\text { as representatives of stakeholders groups }\end{array}$ & Groupings involved in the Jordan Valley NGO master plan initiatives \\
\hline $\begin{array}{l}\text { Public } \\
\text { sector }\end{array}$ & $\begin{array}{l}\text {-Ministry of Agriculture } \\
\text {-National Agricultural Research Centre } \\
\text { (NARC) } \\
\text {-Agricultural Extension Centers, }\end{array}$ & \\
\hline $\begin{array}{l}\text { Private } \\
\text { sector }\end{array}$ & $\begin{array}{l}\text {-General Union of Palestinian Peasants and } \\
\text { Cooperatives } \\
\text {-Palestinian Farmers Union } \\
\text {-Chamber of Commerce and Industry }\end{array}$ & $\begin{array}{l}\text { Representatives of leading clans in the farming communities need to be } \\
\text { represented in the peasants and farmers unions or in the Chamber of } \\
\text { Commerce and Industries }\end{array}$ \\
\hline $\begin{array}{l}\text { Voluntary } \\
\text { sector }\end{array}$ & $\begin{array}{l}\text {-Rural Women Development Society } \\
\text {-Palestinian Agricultural Relief Committees } \\
\text { (PARC) }\end{array}$ & $\begin{array}{l}\text { Grouping of LEISA farms that has as objective to promote LEISA farming } \\
\text { styles in the Palestinian zone of the Jordan Valley }\end{array}$ \\
& $\begin{array}{l}\text {-Palestine Environmental NGO Network } \\
\text { (PENGON) }\end{array}$ & \\
\hline
\end{tabular}


Table 2.21 Stakeholders representing the Palestinian Water Sector

\begin{tabular}{l|l|l}
\hline Sector & $\begin{array}{l}\text { Formal organizations that have been identified } \\
\text { as representatives of stakeholders groups }\end{array}$ & Groupings involved in the Jordan Valley NGO master plan initiatives \\
\hline $\begin{array}{l}\text { Public } \\
\text { sector }\end{array}$ & $\begin{array}{l}\text {-Water Sector Regulatory Council } \\
\text {-Palestinian Water Authority } \\
\text {-Jericho Municipality }\end{array}$ & \\
\hline $\begin{array}{l}\text { Private } \\
\text { sector }\end{array}$ & $\begin{array}{l}\text {-Water users Associations } \\
\text {-Jericho Chamber of Industry }\end{array}$ & $\begin{array}{l}\text { Women organization that represents the women as stakeholder in water and } \\
\text { environmental services in the residential areas of the Jordan Valley }\end{array}$ \\
\hline $\begin{array}{l}\text { Voluntary } \\
\text { sector }\end{array}$ & $\begin{array}{l}\text {-EcoPeace Middle East-Bethlehem office } \\
- \text { PHG }\end{array}$ & \\
\hline
\end{tabular}

Table 2.22 Stakeholders representing the Palestinian Agriculture Sector

\begin{tabular}{l|l|l}
\hline Sector & $\begin{array}{l}\text { Formal organizations that have been identified } \\
\text { as representatives of stakeholders groups }\end{array}$ & Groupings involved in the Jordan Valley NGO master plan initiatives \\
\hline $\begin{array}{l}\text { Public } \\
\text { sector }\end{array}$ & $\begin{array}{l}\text {-Ministry of Agriculture } \\
\text {-National Agricultural Research Centre } \\
\text { (NARC) } \\
\text {-Agricultural Extension Centers, }\end{array}$ & \\
\hline $\begin{array}{l}\text { Private } \\
\text { sector }\end{array}$ & $\begin{array}{l}\text {-General Union of Palestinian Peasants and } \\
\text { Cooperatives } \\
\text {-Palestinian Farmers Union } \\
\text {-Chamber of Commerce and Industry }\end{array}$ & $\begin{array}{l}\text { Representatives of leading clans in the farming communities need to be } \\
\text { represented in the peasants and farmers unions or in the Chamber of } \\
\text { Commerce and Industries }\end{array}$ \\
\hline $\begin{array}{l}\text { Voluntary } \\
\text { sector }\end{array}$ & $\begin{array}{l}\text {-Rural Women Development Society } \\
\text {-Palestinian Agricultural Relief Committees } \\
\text { (PARC) }\end{array}$ & $\begin{array}{l}\text { Grouping of LEISA farms that has as objective to promote LEISA farming } \\
\text { styles in the Palestinian zone of the Jordan Valley }\end{array}$ \\
\hline -Palestine Environmental NGO Network \\
(PENGON)
\end{tabular}

endorsed the "Action Plan for Reform" towards the definition and implementation of a comprehensive program of institutional and legislative reform in the Palestinian water sector. In June 2014 a new water law was passed. An important issue of this water law is the establishment of a Water Sector Regulatory Council (WSRC).

The main objective of the WSRC is to monitor all matters related to the operation of water service providers, with the aim of ensuring water and wastewater service quality and efficiency to consumers in Palestine at affordable prices. The council monitors operational performance related activities of water service providers including production, transportation, distribution, consumption, wastewater collection, treatment and disposal, and reuse of treated wastewater for irrigation.

The PWA shares responsibility for irrigation development with the Directorate of Soil and Water Management in the Ministry of Agriculture (MoA) and the Environmental Protection Section of the Environmental Quality Authority. These public organizations are expected to provide irrigation support services to individual farmers and community-based groups who own and manage the local irrigation system. The community-based groups are encouraged to organize themselves into water users associations to enhance technical and managerial capacities and to clarify land and water rights and management responsibilities for efficient user's provision of irrigation services.

The Directorates of Agricultural Services and Soil and Water Management of the Ministry of Agriculture are the main public service providers for irrigated agriculture. The Directorate of Agricultural Services is responsible for agricultural research and agricultural extension Services. The National Agricultural Research Centre (NARC) coordinates the research stations, which are linked to 17 Agricultural Extension Centers that coordinate the frontline staffs of the public agricultural support services.

There is not yet an umbrella organization of Water Users Organizations that can represent the interests of the water user organizations at supra-local and national level. The General Union of Palestinian Peasants and Cooperatives and the Palestinian Farmers Union represent the user organizations in the policy dialogue platforms and take an advocacy function for users groups involved in local irrigation and drainage development initiatives. For the representation of potential investors in the upgrading or establishment of agro-industries, the involvement of the Jericho Chamber of Commerce and Industry needs to be considered. 
The Palestinian Agricultural Relief Committees (PARC) was established in the early 1980s as a response to the lack of agricultural extension service during the Israeli occupation. The NGOs adopted a dynamic development process where the focus of the committees shifted from voluntarism (1983-87) to development and expansion (1988-92), and via institutionalization (1993-99) it ended in a network organization structure (2000-present). At the current networking stage the organization of beneficiaries are considered as a mean to make extension services more demanddriven and to build democratic and outward-oriented organizations in farming communities.

Rural Women's Development Society (RWDS) is a women's non-governmental organization that works in rural areas in Palestine aiming at empowering rural women. RWDS was initially a women committee within PARC, and in 2001 it was officially registered as an independent NGO. The RWDS has focused on rural livelihood issues and established 65 women's clubs that represent more than 4300 members and beneficiaries and the number is still increasing. RWDS believes in gender equality in all life aspects and it works at ensuring women's involvement in rural development and capacity building initiatives.

\subsubsection{Governance of the Jordan Valley}

This section provides an overview of the governance structure and major governmental organizations and their responsibilities in the Jordan Valley.

\section{Jordan}

Ministry of Planning and International Cooperation (MOP)

MOP's role is to channel funds from international donors. MOP is also carrying out programs that contribute to small scale enterprise development.

Jordan Valley Authority (JVA) under the Ministry of Water and Irrigation (MWI)

Water

\section{Water Authority of Jordan (WAJ)}

The tasks of JVA and the WAJ are not precisely delineated. Both are dealing with water resources development. JVA focuses on water to be used in the Jordan Valley, especially for irrigation, WAJ focuses on water for domestic and industrial use. Consequently, JVA's activities are not all confined to its mandate area, depending on the sources of water.

\section{Ministry of Environment (MOE)}

The Ministry of Environment (MOE) was created in 2003 and is still in the process of institutional development and internal capacity building, and of preparation of its legislation. MOE is responsible for environmental protection as a whole, including nature conservation. RSCN is assisting MOE in environmental legislation (for example regulation on protected area designation) based on more profound experiences in this field. The Ministry of Environment delegated the RSCN to manage the natural reserve under the supervision of the Ministry through a memorandum of understanding (MoU). Through this $\mathrm{MoU}$ both work on preparing management plans for natural reserves. Also, based on this MoU both have cooperated together on issues related to biodiversity and conservation under international conventions. In addition to that the MOE is responsible of declaring new natural reserves.

Ministry of Tourism and Antiquities (MOTA)

The Ministry of Tourism and Antiquities (MOTA) is responsible for management of the tourist sector and the antiquities in the Jordan Valley.

\section{Ministry of Agriculture (MOA)}

The Ministry of Agriculture (MOA) supports the agricultural sector and governs the natural forests in Jordan, based on the Provisional Law of Agriculture No. 44 (2002), which describes the responsibility for achieving the objective of "sustainable use of the natural agricultural resources without harming the environment", and for "combating desertification and conserve biodiversity". The Agricultural Law focuses on plant production, protection, animal production, health, and includes a number of articles concerning forests/forest lands and rangelands and fishery. Desertification control and biodiversity conservation are also vested in the law. Biodiversity is given explicit attention in articles on protection of wild birds and wild animals in the Law of Agriculture. Important activities are Forestry, Rangelands and Agricultural production support, promotion of integrated pest management and biological farming, Plant Protection, Extension services. Furthermore it houses the National Centre for Agricultural Research and Technology Transfer (NCARTT).

\section{Ministry of Municipal Affairs (MOMA)}

The Ministry of Municipal Affairs (MOMA) may play a role through municipalities as a focal point for local level and alternative livelihood development.

\section{Ministry of Transport (MOT)}

The Ministry of Transport (MOT) has the overall statutory authority for transport planning in Jordan.

\section{Department of Land and Surveys (DLS), Ministry of Interior}

The Department of Land and Surveys (DLS) is responsible for land management and registration. 


\section{Natural Resources Authority (NRA)}

The Natural Resources Authority (NRA) is responsible for mineral exploration. In its latest map (2005) of potential mining areas, sites are depicted both inside and outside protected areas.

\section{Jordan Army Forces (JAF)}

The Jordan Army Forces (JAF) is important, since is manages the security zones along the western and northern borders in the Jordan Valley. JAF has reportedly expressed its willingness to allow access to the areas for ecological surveys and other project activities.

\section{Geographic Centre}

The Geographic Centre is the traditional source for topographic maps and some thematic maps.

\section{Department of Statistics (DOS)}

The Department of Statistics is responsible for managing and dissemination of statistical information about Jordan for a wide variety of sectors.

\section{Israel}

Ministry of Energy and Water Resources

The MEWR is in charge of securing a supply of energy considering reliability, availability, efficiency and quality needed for a highly developed, modern national economy, at an optimal economic, social and environmental cost. The Ministry of Energy and Water Resources is also responsible for the energy economies and national resources of the State of Israel: electricity, fuel, cooking gas, natural gas, energy conservation, water, sewer mains, oil exploration, ores, scientific research of soil and the sea and more. The Ministry supervises the public and private entities involved in these fields and acts to ensure an adequate solution to the changing energy and infrastructure needs of the national economy, today and in the future, while regulating the market and protecting the consumer and the environment.

\section{Israeli Water Authority}

Israeli Water Authority (IWA) is the government's executive branch in charge of Israel's water economy, it is responsible for the administration, operation and development of the Israeli water economy, including the preservation and restoration of natural water resources, the development new water resources and the oversight of water consumers and producers, to allow high quality water and sewage services of optimal reliability, while increasing the sustainable welfare of Israeli citizens.

\section{Mekorot}

Mekorot, Israel's national water company, operates under the supervision of the Minister of Energy and Water Resources, and is responsible for supplying the Israeli population with water. Mekorot's water supply system unites most regional water plants, the National Water Carrier System and the Yarkon Negev Facility. One of its tasks is to integrate waters from the Kinneret, the shore and mountain aquifers, drilling waters, seawater and desalinated waters in its overall water supply strategy.

Ministry of Agriculture and Rural Development (MOAG)

Ministry of Agriculture and Rural Development (MOAG) is responsible for agriculture, land preservation and veterinary services. MARD is also planning the development of rural areas in terms of public and private service institutions, development of physical rural infrastructures, conservation and prevention of environmental nuisances, rural soil preservation and drainage.

\section{Ministry of Environmental Protection (MEP)}

The Ministry of Environmental Protection is responsible for protection of the environment and ecosystems, as well as sustainable development. MEP operates nationally, regionally and locally. Among other things, the ministry is responsible for formulating and implementing a national environmental protection policy, enforcing environmental legislation in local authorities and serving as an advisory body to municipalities. With regard to river rehabilitation the Ministry supports and promotes removal of polluting components and sources; assurance of permanent sources of water at the required quality to the river; conservation of open spaces and ecosystems in the vicinity of the river, establishment of tourist and recreation centers based on nature and cultural assets in the environs of the river, promotion of public awareness of the condition of the streams and their importance to the landscape and open space.

Israeli Meteorological Service (IMS)

The Israel Meteorological Service (IMS) provides a variety of meteorological, climatic and supplementary services. Services include forecasting, monitoring, analyzing interpreting the weather and climate the region while maintaining national and international cooperation and conforming to national and international standards.

\section{Israel Nature and Parks Authority (INPA)}

Israel Nature and Parks Authority (INPA) protects nature and heritage sites, and educates the public accordingly. Its assets, nature reserves and national parks are public properties. Services include protecting nature, making sites accessible to the public, conserving and reconstructing heritage, planning and development.

\section{Lower Jordan River Drainage Authority}

The Lower Jordan River Drainage Authority was established in October 2009 in order to promote and coordinate conservation activities, rehabilitation and development in the river area. The activities of the river authority are coordi- 
nated by the drainage authority. Members of the river authority includes the ministry for regional development, the Ministry of environmental protection, the Ministry of agriculture and rural development, the Ministry of interior, the Ministry of tourism, the Ministry of Defense, the Ministry of foreign affairs, the Israel Water authority, the South Jordan drainage authority, the Jewish National Fund, the Springs Valley Regional Council, the Israel Nature and Parks Authority, representative of various Israeli green NGOs, the Israel land administration, the Israel antiquities authority and the Regional Water provider-Afikey maim.

The LowerJordan River Drainage Authority is responsible for drainage and water management in the Jordan Valley from Naharyim to the Bezeq Stream. Its plans are aligned with other national and regional plans, such as the below Kinneret Drainage Authority, responsible for the area from the Deganiya Dam (where the Lower Jordan exits the Sea of Galilee) to Naharyim.

\section{Kinneret Drainage Authority}

The Kinneret Drainage Authority is responsible for the section of the Jordan Valley from the Kinneret/Sea of Galilee to Naharyim. It is responsible for drainage and water management and is presently implementing river rehabilitation efforts in its section of the river.

\section{Ministry of Tourism}

The Ministry of Tourism is responsible for the tourism industry in Israel, which is the employer of 60,000 people throughout the country.

\section{Ministry of Economy and Trade}

The Ministry of Economy and Trade in governing local and foreign investments by offering a wide range of incentives and benefits to investors in industry, tourism and real estate. It is in charge of the promotion of economic growth in Israel.

\section{Ministry of Regional Co-operation}

The Ministry of Regional Cooperation deals with facilitating cross border cooperation projects with Jordan and the Palestinian Authority in terms of economic co-operation and infrastructure development.

Ministry for Development of the Negev and the Galilee

The Ministry for Development of the Negev and the Galilee is responsible for advancing and promotion of the Negev and the Galilee regions and place them at the top of the government's list of priorities. It deals with infrastructure, industry and employment, settlement and housing as well as education and culture.

Ministry of Finance

The Finance Ministry overlooks all national budgetary decisions.

\section{Ministry of Interior}

The Interior Ministry overseeing Israel's urban planning agencies and municipal affairs.

\section{Ministry of Defense}

The Ministry of Defense holds control over Israel's military, and is the supreme agency in charge of governing the Jordan Valley from the Bezeq Stream to the Dead Sea in accordance with the Oslo Agreements.

\section{The Antiquities Authority}

Israel antiquities authority is in charge of the country's antiquities and antiquity sites, their excavation, preservation, conservation, study and publication thereof, as well as the country's antiquity treasures.

\section{Beit Shean Municipality}

Largest Israeli city in the Jordan Valley.

\section{Jordan Valley Regional Council}

Extends from the north of the Sea of Galilee down the eastern side and then along both banks of the Jordan River until the confluence with the Yarmouk River at Naharyim.

\section{The Valley of Springs Regional Council}

The Valley of Springs Regional Council is the regulator of municipal services for the villages within its territory from Gesher to the Green Line (Fig. 2.25)

The Palestinian Authority governs the areas A and B in the West Bank study area through the following governmental organizations: Office of the Prime Minister; Ministry of Finance; Ministry of National Economy; Ministry of Agriculture; Environmental Quality Authority; Ministry of Local Governorates and Municipalities; Ministry of Health; Palestinian Water Authority.

But despite being a riparian to the Jordan River, the Palestinian Authority (PA) has de facto no direct control over the Lower part of the Jordan River itself and little over the surrounding riparian zone. As a result of the Interim (Oslo I and II) Agreements, and the agreement on the handover of responsibilities between the Palestine Liberation Organization and the government of Israel, the Jordan Valley was divided to 3 different categories of land, security and civil administration (A, B and $\mathrm{C}$ ).

This division has resulted in a serious problem for the enforcement of laws and Palestinian development potential in the Jordan Valley, whereby any establishment that is to be created (whether residential or commercial) must receive its licensing and building permits from the Israeli Ministry of Defense's Civil Administration. This does not function in accordance with the PA's development plans, and causes tremendous delays and costs to development plans. Furthermore, access to the river by Palestinians is limited, and thus, there is little domestic Palestinian tourism or other use 


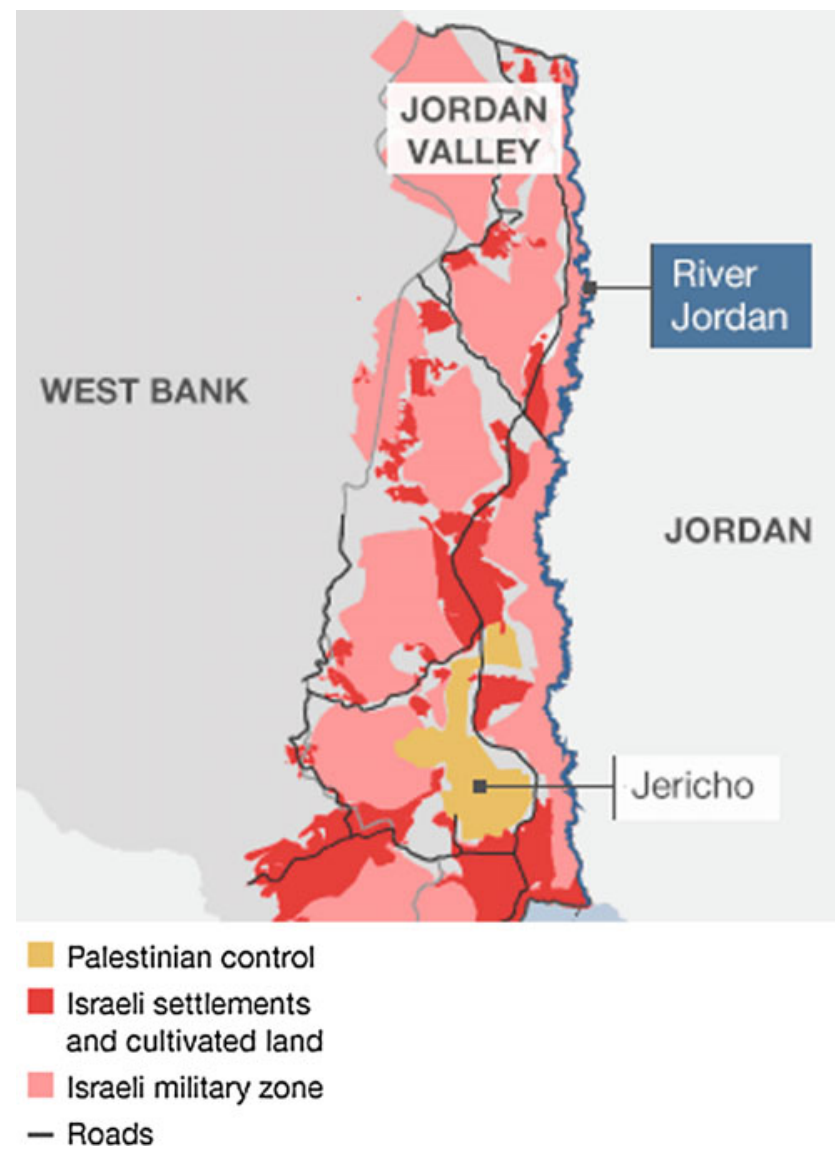

Fig. 2.25 Palestinian versus Israeli control in the Jordan Valley

of the river. In 2003, the Water Law has been issued by the Palestinian Authority.

Palestinian Water Authority (PWA)

In 2003, the Water Law has been issued by the Palestinian Authority. The Palestinian Water Law stipulates establishment of the Palestinian Water Authority and assigns to it the responsibility for the management/regulation of water, drainage and sewage affairs. Also, the law stipulates that a draft Water, Drainage and Sewage Plan to be prepared by the Planning Department of the Palestinian Water Authority. Although the law transfers the licensing jurisdiction to the PWA and requires the detailed water registry, the ownership of the water resources is not transferred to the Palestinian Authority. The Palestinian Water Authority (PWA) has prepared a draft of National Water Strategy in 2012 which defines how the water resources in the occupied Palestinian territory will be managed in an integrated manner outlining the massive investment program of projects and activities needed for water sector development in the occupied Palestinian territory from 2012 till 2015.

Palestinian Environmental Quality Authority

The Palestinian Environmental Quality Authority is responsible for implementation of the environmental law of 1999. It has the objectives to protect the environment against all forms and types of pollution, to protect Public health and welfare, to insert environmental protection in social and economic Palestinian development plans, to encourage sustainable development of vital resources in a manner that preserves the rights of future generations, to protect bio-diversity and environmentally sensitive areas, as well as improvement of environmentally harmed areas, and to encourage collection and publication of environment related information to raise public awareness of environmental problems.

Ministry of Tourism and Antiquities (MOTA)

MOTA is responsible for governing the tourist sector and the antiquities in Palestine. The basic law of 1968 is currently being updated to adapt to current challenges and needs. The new law will identify the variety of accommodations and agents, restaurants and other facilities. It will also indicate a general structure for the public private joint leading council that will carry responsibilities in marketing and development. A new hotel classification system is underway and expected to have all hotel in Palestine classified between 1 and 5 stars by end of 2013. An ad hoc joint committee was established for this purpose. Other initiatives are also underway on the level of tourism signage, tourism education, and rehabilitation of archeological sites and other antiquities. Enforcement of the aforementioned laws in the Jordan Valley is of the utmost importance.

\subsubsection{Current International Agreements and Co-operation Issues}

The international legal agreements applicable to the Jordan Valley include the following:

\section{The Helsinki Rules}

The Helsinki Rules, on the Uses of the Waters of International Rivers, adopted by the International Law Association in 1966 and the 1997 UN Convention on the Law of the Non-Navigational Uses of International Watercourses are two of the most referenced and developed of international legal agreements on the uses of transboundary watercourses. These legal agreements could also provide a framework in 
which freshwater is shared between Israel and Palestine in an equitable manner, and which takes into consideration environmental concerns and future water needs.

The current restrictions on Palestinian water use do not meet the criteria for equitable sharing between riparian parties of the Jordan Valley. Agreement on the available water quantities to be distributed on an equitable basis is thus needed in order to provide a basis for sustained management of these limited water resources.

\section{The UNESCO Convention}

The UNESCO Convention concerns the Protection of the World Cultural and Natural Heritage of 1972. Palestine became a state party to the agreement in 2011. The Jordan Valley should fall under the protection of this agreement as a cultural and natural heritage area. An important step forward would be to advance the listing of the Jordan Valley under UNESCO in a trilateral fashion.

Other international agreements that are applicable to the Jordan River are:

i. The Seoul Rules on International Groundwaters (Adopted by the International Law Association at the Sixty-Second Conference Held at Seoul in 1986)

ii. The Berlin rules 2004 (an update of the Helsinki rules that are already added in the international legal agreements section).

iii. United Nations Convention on Biological diversity (1992) and Cartagena Protocol on Biosafety;

iv. Convention on International Trade in Endangered Species (CITES);

v. Ramsar Convention (Wetlands);

vi. Bonn Convention on Migratory Species;

vii. The Hague conventions and fourth Geneva convention: international Humanitarian law/international customary law;

\section{Bi-lateral Agreements}

The Declaration of Principles is the first Bi-lateral Agreement between the PLO and Israel signed on 13 September 1993. According to this agreement, water issues were to be discussed by the Permanent Palestinian Israeli Committee for Economic Co-operation. It was agreed to prepare plans for water rights, and equitable use of water for the shared resources. However, this agreement did not quantify the water right for each party.

The Gaza Jericho First Agreement is the temporary Agreement regarding autonomous rule of the Palestinian Authority in Jericho and the Gaza Strip, signed on 4 May, 1994. Article 2 paragraph 31 deals with the water issues in the two regions. Limited authority on water uses was transferred to the Palestinian Authority.

\section{Bi-lateral Water and Wastewater Agreements}

The water and wastewater sectors in Palestine are governed by two agreements with the Israeli side:

The Palestinian-Israeli Interim Agreement on the West Bank and Gaza Strip, Washington, D.C, September 28, 1995; Annex 3, Protocol Concerning Civil Affairs, Article 40, Water and Sewerage. Essentially Article 40:

The agreement was based on Israel's recognition of Palestinian water rights in the West Bank. It sets governance arrangements for a 5 year interim period, notably a Joint Water Committee (JWC) to oversee management of the aquifers, with decisions to be based on consensus between the two parties. It allocates to either party specific quantities of the three West Bank aquifers underlying both territoriesthe share allocated to the Palestinian West Bank was about one quarter of the allocation to Israel and the settlements. It provides for interim extra supplies from new wells and from Mekorot as immediate needs an extra 28.6. MCM was to be allocated to Palestinian needs. Finally the agreement estimates needs for the interim period for the Palestinian West Bank at 70-80 MCM.

The Memorandum of Understanding (MOU) on Guidelines and Technical Criteria for Sewerage Projects, signed on December 31, 2003, Israeli-Palestinian "Joint Water Committee".

The MOU sets out agreements for the collection systems, wastewater treatment, sludge treatment, effluent reuse and disposal, sludge reuse and disposal and cooperation between the two sides. The very high standards in this MOU restrict donors' involvement and makes implementation costly and very difficult for Palestinians even though a phased implementation approach to meeting requirements has been agreed upon.

The MOU version 2 is the most recent document that governs wastewater treatment and reuse standards and will consequently drive the treatment technology and reuse strategies that will be used in Palestine. The interim water and wastewater Agreement "Article 40" of Oslo 2 will be used as the basis for water sector planning and project implementation during the "interim period" and until a final status agreement is reached. These are to be negotiated and settled in the Permanent Status Agreement relating to the various water resources. (4)

Trans-boundary Water Management Issues between Israel and Palestine as relevant to the Jordan Valley

An Israel-Palestinian Treaty of Peace is not in place. With regard to water related matters the following information is of particular importance within the context of this situation. 


\section{Water Resources}

Prior to 1967 , Israel had developed the water resources to which it had access and established the National Water Carrier to supply agricultural, municipal and industrial water demands. Since 1967 Israel took control of water resources in the West Bank as well, together with water supply networks serving Israeli settlements in the West Bank. At the same time Palestinian water rights in Palestine were abrogated, including from the Jordan River.

Currently, the economic disparity between Palestine and Israel is large, and the water resources availability to the two neighbors is likewise far apart, with fresh water per capita in Israel much higher than that of Palestine. Whereas Israel has been able to develop an efficient water infrastructure and management, the Palestinians are still struggling to attain the most basic level of infrastructure and services of a low income country. Furthermore, the Palestinian water infrastructure systematically suffers from lack of development because of Israeli restrictions and obstacles and this is particularly evident in the Jordan Valley.

Above all, a just settlement between Israel and Palestine is a prerequisite to real improvements and achieving effective water governance in Palestine, including the current study area. WEDO/EcoPeace's proposal for an Agreement to Share Water between Israelis and Palestinians (March 2012) might serve as an example on how to adopt a joint water management structure for Israel and the future State of Palestine. The proposed structure allows for ongoing resolution of issues concerning fresh water by de-nationalizing and de-securitizing water uses. WEDO/EcoPeace proposes to share water by rules that are designed to protect the ecosystem for everyone's benefit, and to deliver water to all parties in ways that meet their needs and equitable rights.

\section{Paris Protocol Bilateral Trade Agreement}

Additionally, Palestine and Israel are bilaterally bound by the Paris Protocol. However, the agreement is partially and ineffectively implemented. The Paris Protocol (PP) was signed in 1994 as an interim economic agreement to maintain the free movement of goods and labor between Palestine and Israel within the framework of customs union. The Palestinians viewed that, with international aid and support, the Paris Protocol provides the basis for sustainable growth of the Palestinian economy. However, facts are in sharp contrast with this vision. The Israeli restrictions of movement of goods and people, and closure of roads and areas, resulted in one sided decision making of the Israeli power, and a weakness in the Palestinian economy. The latter created a dependency on the Israeli market for goods and labor and in a huge structural economic imbalance between the two economies. The implementation of the Paris Protocol in accordance with its basic rules of free movement of labor and goods would have encouraged fair trade between
Palestine and Israel and supported the development of a viable Palestinian economy.

\section{Security Arrangements Along the Jordan River}

Since 1967, the Jordan River has been under the control of the Israeli and Jordanian military, which operate checkpoints and bases on both sides. The Palestine side of the Jordan River is under Israeli military control since 1967. The area contains covert listening stations, radar sweeps and thermaland night-vision cameras. On the mountain tops that rise steeply from the valley floor, Israel maintains a series of early-warning stations. Troops are on constant patrol along the river and the passes, and on both sides of the river a key strip of land is inaccessible for the general public.

On the Israeli and Palestinian side of the river, more than 1,000 ha have been mined, including both antipersonnel and antitank mines. Mined areas are also located near villages such as Kfar Ruppin and include parts of nature reserves such as the East Gilboa Reserve. They also include former Syrian minefields. In the late $90 \mathrm{~s}$ the Israeli Ministry of Tourism initiated activities to remove former Syrian mines in certain areas along the Jordan River suspected of containing Syrian antipersonnel mines, such as around Kibbutz Gesher. Along the river, Israeli and Jordanian mine fields are still part of the overall security framework.

Israel and Jordan are connected though the Sheikh Hussein Bridge in the north, and Palestine (West Bank) with Jordan through the King Hussein (Allenby) Bridge. These bridges are subject to strict security measures in terms of trans-passing persons and goods. The King Hussein Bridge is located just outside Jericho city and is the only connection between the Palestinian West Bank and Jordan. The West Bank side of the King Hussein/Allenby Bridge is considered a border entry point by the Israeli Authorities. The Jordanian authorities recognize the bridge as an international border entry point between Jordan and Palestine, but in contrast to other border crossings, they do not grant entry visas to foreign passport holders at this crossing. Palestinians from the West Bank traveling abroad use this bridge to exit the West Bank into Jordan, since they are not permitted to use Ben Gurion Airport near Tel Aviv. Travel permits from Israeli authorities are required, with varied stringency depending on the political and security situation. Israeli citizens are not permitted to use the terminal. Travel permits for Palestinians are not required by the Jordanian authorities.

\section{Trans-boundary Water Management Issues Among Israel and Jordan}

The Israel-Jordan Treaty of Peace, sometimes referred to as the Wadi Araba Treaty, was signed by the State of Israel and the Hashemite Kingdom of Jordan in December 1994. With regard to water related matters, the following elements of particular importance within the context of the current study. 


\section{Water Allocation from the Yarmouk River}

The agreement stipulates that during the summer period from 15 May to 15 October of each year, Israel shall receive 12 MCM and Jordan is to retain the rest of the Yarmouk water flow. During the winter period, from 16 October to 14 May of each year, Israel is entitled to receive $13 \mathrm{MCM}$ and Jordan is to keep the rest of the flow. Furthermore, Israel is entitled to borrow an additional $20 \mathrm{MCM}$ during the winter period, to be transferred back to Jordan during the next summer. With regard to excess flood waters from the Yarmouk that would otherwise flow into the Lower part of the Jordan River, it was agreed that both Jordan and Israel are allowed to utilize this water in equal portions for their own purposes.

\section{Water Resources from the LJR}

The agreement stipulates that during the summer period of each year, Jordan shall receive $20 \mathrm{MCM}$ from the Lower part of the Jordan River upstream of the Yarmouk from Israel. During the winter period Jordan shall receive an additional 20 MCM from Israel from the LJR south of the Yarmouk. With regard to remaining water flows in the LJR south of the Yarmouk it was agreed that both Jordan and Israel are allowed utilize this water in equal shares for their own purposes, provided that neither party would harm the water quality of the LJR. A Joint Jordanian-Israeli Water Committee has been established to monitor the actual water flows and water allocations.

\section{Saline Springs and additional water resources}

Furthermore the agreement stipulates that Jordan is entitled to receive $10 \mathrm{MCM}$ of desalinated water from Israel, originating from the saline springs near the Sea of Galilee, provided that this is financially feasible. If so, it has been agreed not to discharge the brine into the Jordan Valley. Currently, this saline water is conveyed from these springs directly to the LJR through the Saline Water Carrier by Israel. The agreement confirms that Israel will explore the possibility of financing the operation and maintenance cost of supplying this desalinated water to Jordan, while Jordan will explore the possibilities to finance the required capital expenditures. Finally the agreement includes the intension to jointly develop an additional $50 \mathrm{MCM}$ of drinkable water, without yet specifying its source, for the benefit of Jordan.

\section{Operations and Maintenance}

From an operational point of view, the agreement states that Israel accepts responsibility for operating, supplying and maintaining systems on Israeli territory that supply water to Jordan. Under this set-up Jordan is allowed to choose the related Operator, provided these operations only serve Jordan (so not Israel at the same time). Israel guarantees easy access for the involved operations personnel and equipment.

\section{Water Storage}

Both parties agree to co-operate in the development of a new water storage dam in the Yarmouk River, downstream of the Adassiya Diversion, and of a storage facility in the LJR south of the Yarmouk confluence and north of the Bezeq stream.

\section{Water Quality}

Both parties agree to protect the Jordan and Yarmouk Rivers and related groundwater systems and water supply systems against pollution, contamination, harm and unauthorized withdrawals of each other's allocations. They agree to jointly monitor the quality of water along their border, using jointly (to be) established monitoring stations under the Joint Water Committee. This includes treatment of municipal and industrial wastewater to agricultural standards before discharging it into the Yarmouk and the Jordan Rivers.

\section{Information and Notification}

The agreement stipulates that the Joint Water Committee is the official body through which relevant data on water resources is to be exchanged. The JWC can assign sub-committees to perform technical tasks, such as a northern sub-committee and a southern sub-committee. Furthermore, deliberate changes in the Jordan and Yarmouk Rivers require prior mutual agreement. In particular, both parties agreed to 6 months advance notice of projects likely to change the quality or flow of either river along their common boundary via the Joint Water Committee. Also, planning for increasing water supplies and improving efficiency is to be done in a co-operative manner within the context of bilateral, regional or international cooperation agreements.

\subsubsection{Outlook for Future Security Arrangements}

During the 2013 and 2014 Peace Negotiations between the Palestinians and Israeli's, the security arrangements in the Jordan Valley as part of any final settlement between the two parties was one of the key issues in dispute. In line with this Master Plan, the Jordan Valley should be an integrated part of the independent Palestinian State, with eventual full control by the Palestinian Authorities.

According to the Israeli's, the Jordan Valley forms the closest border to the heartland of Israel, and is considered by many as the only realistic eastern topographically defendable border against potential aggression from the east. The political upheaval in the Middle East and the violence in Syria and Iraq have already caused a large stream of a great variety of refugees entering Jordan. Israel fears that some of 
these refugees may attempt to infiltrate into Israel. This, together with the radical forces active in these countries and the fear that extremists with advanced weapons will be smuggled into the West Bank underlines the notion that a well-defended eastern border is essential for the security of the Israeli people, including secure road access from the west.

At the outset of the recent peace talks, the Palestinian position on this subject recognized the need for a transition period in which Israel would retain some military presence in the Jordan Valley, say up to about 5 years. After this period the Palestinians would agree on the deployment of international forces, such as UN forces or NATO along the Jordan River as a way to ensure security and allay Israeli fears, be it without any Israeli soldier left behind.

The Israeli position on this subject welcomes cooperative security arrangements with the Palestinians and Jordan under a final settlement, but rejects the idea that at a certain date international forces, such as UN or NATO, would fully replace Israeli troops, since this would undermine Israel's ability to act effectively against terrorist infiltration and weapons smuggling, or to provide a first line of defense against any other future threat from the east. During the present war in Syria in which the UN peacekeeping troops withdraw their contingents, when under attack, decreased even further the trust and willingness of Israel to place security responsibility completely in the hand of third parties.

During the recent peace negotiations, the United States attempted to bridge this gap by drawing on U.S. security experiences in Afghanistan, and proposing the use of high level U.S. provided intelligence and technology, such as advanced sensors; drones and high-tech fences. It has been proposed that during the transitional period, there will remain some Israeli military presence in the Jordan Valley at roughly about 200-500 troops plus a number of civilian Israeli security personnel at the border crossings co-operating closely with Palestinian and Jordanian security forces. During this period the security structure would shift towards higher security technology (e.g., scanners, sensors, sniffers, remote sensors etc.), while progressively handing over certain security responsibilities to Palestine and Jordan.

Although both parties seem to have been sympathetic to elements of these ideas, eventually Israel seem to have classified them as too much reliance on technology as a substitute for essential military people. The Palestinians on the other hand seem to have rejected this concept, since they rule out any kind of enduring Israeli presence in the Palestinian State once the transition period has concluded.

However, similar challenges have been faced in the past. For instance, during the negotiations for the 1979 peace treaty between Israel and Egypt, both parties repeatedly rejected mutual security proposals, whereas today the situation has evolved into a generally acceptable security framework, including a set of strict security regulations and a framework for mutually tolerated ad hoc interventions when needed. Within the framework of this Master Plan it is believed that continuing the joint Palestinian-Israeli security negotiations on a factual and security-technical basis will eventually lead to a joint security solution for both the transition period and beyond, doing justice to the legitimate rights of the Palestinians for a free, sovereign and independent state, and the legitimate security rights of the Israeli people.

Open Access This chapter is distributed under the terms of the Creative Commons Attribution 4.0 International License (http:// creativecommons.org/licenses/by/4.0/), which permits use, duplication, adaptation, distribution and reproduction in any medium or format, as long as you give appropriate credit to the original author(s) and the source, a link is provided to the Creative Commons license and any changes made are indicated.

The images or other third party material in this chapter are included in the work's Creative Commons license, unless indicated otherwise in the credit line; if such material is not included in the work's Creative Commons license and the respective action is not permitted by statutory regulation, users will need to obtain permission from the license holder to duplicate, adapt or reproduce the material. 